\title{
Izobraževalna tehnologija in izgradnja avtentičnega učnega okolja
}

Andreja Istenič Starčič

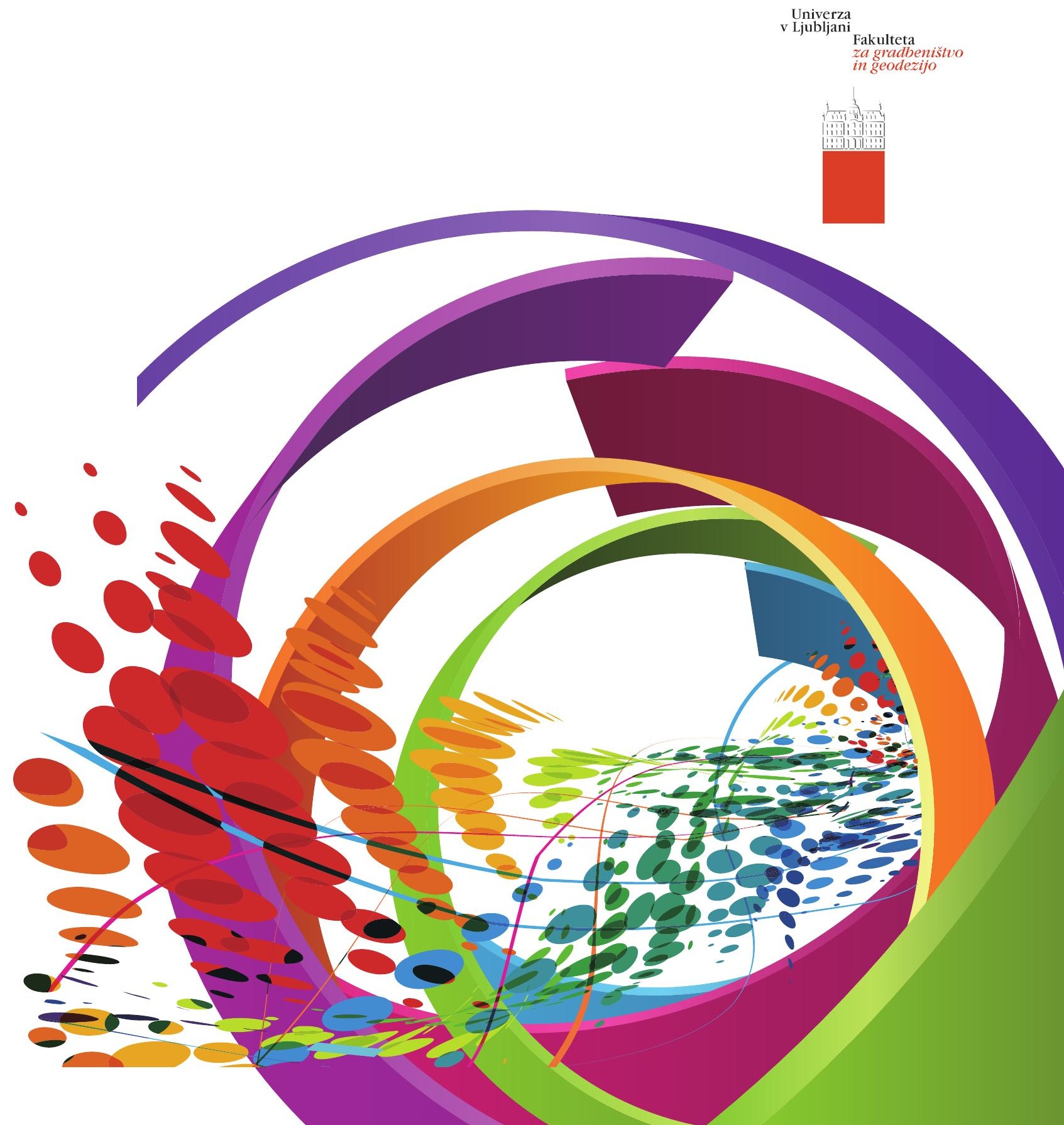


Andreja Istenič Starčič

Izobraževalna tehnologija in izgradnja avtentičnega učnega okolja

Znanstvena monografija: 1. izdaja

Recenzenta: Martin Kramar in Matjaž Debevc

Lektura: Tina Praček

Oblikovanje in tehnična ureditev: Denis Starčič

Izdala in založila: Univerza v Ljubljani Fakulteta za gradbeništvo in geodezijo,

zanjo dekan: prof. dr. Matjaž Mikoš

Bibliografsko-informacijska obdelava: Teja Koler Povh

Soizdajatelj: Univerza na Primorskem

Ljubljana 2020

Publikacijo je sofinancirala Javna agencija za raziskovalno dejavnost Republike Slovenije (P2-0210).

Publikacija je brezplačna.

Publikacija je odprtodostopna pod licenco

CC BY 4.0-NC-ND

To je elektronska izdaja, dostopna na naslovu:

https://repozitorij.uni-lj.si/IzpisGradiva.php?id=116682

DOI: $10.15292 /$ Itiauo.2020.01

Kataložni zapis o publikaciji (CIP) pripravili v Narodni in univerzitetni knjižnici v Ljubljani

COBISS.SI-ID $=17903875$

ISBN 978-961-6884-70-9 (pdf) 


\section{Kazalo vsebine}

Uvod: Izobraževalna tehnologija $\quad 1$

Izobraževalna tehnologija za razvoj kompetenc 21. stoletja 4

$\begin{array}{ll}\text { Pomen digitalne in medijske pismenosti } & 6\end{array}$

Dejavniki uporabe izobraževalne tehnologije 11

Izobraževalna tehnologija v vzgojno-izobraževalnem procesu $\quad 17$

Izobraževalna tehnologija v globalnem sistemu dejavnikov

vzgojno-izobraževalnega procesa $\quad 22$

Izobraževalna tehnologija v strukturi vzgojno-izobraževalnega procesa 26

Otrokovo primarno okolje in digitalna tehnologija 28

Trendi preučevanja vpliva digitalnih tehnologij v otrokovem okolju 28

Digitalna tehnologija v otrokovem igralnem okolju 32

Starševska mediacija pri uporabi digitalnih tehnologij 37

Partnerstvo vzgojitelja s starši

$\begin{array}{ll}\text { Priporočila in tveganja } & 44\end{array}$

Izobraževalna tehnologija pri strukturiranju vzgojno-izobraževalnega okolja $\quad 48$

Didaktična načela

Vrste igre in izobraževalna tehnologija $\quad 55$

Izobraževalna tehnologija pri strukturiranju učnih ciljev

in ergonomske značilnosti njene uporabe po področjih učenja 58

Načrtovanje in spremljanje $\quad 62$

$\begin{array}{ll}\text { Digitalno pripovedovanje zgodb } & 67\end{array}$

Pripovedovanje kot učna metoda in opredelitev pojma 67 
Preučevanje značilnosti pripovedovanja zgodb in vključevanje v kurikul

Pristopi in oblike pripovedovanja zgodb

Značilnosti digitalnega pripovedovanja zgodb

Primer uporabe digitalnega pripovedovanja zgodb pri poučevanju evolucije

Povzetek

Abstract

Imensko kazalo 82

Stvarno kazalo 99

Literatura

101

Recenzija - Martin Kramar

118

Recenzija - Matjaž Debevc

122 



\section{Uvod: Izobraževalna tehnologija}

Izobraževalna tehnologija je v Sloveniji sestavni del didaktike (Blažič, Ivanuš Grmek, Kramar in Strmčnik, 2003). Didaktika je pedagoška disciplina, ki je uveljavljena zlasti v nemškem in slovanskem prostoru (Strmčnik, 2001). F. Strmčnik navaja opredelitev didaktike, ki jo je podal G. Šilih »... kot teorijo 'o izobraževanju in pouku' (1961, str. 32), pri čemer je pouk pojmovan kot vzgojno-izobraževalni proces« (Strmčnik, 2001, str. 20). V okviru didaktike se izobraževalna tehnologija v procesu učenja in poučevanja povezuje s pedagoško psihologijo, pedagoško sociologijo, filozofijo vzgoje, vodenjem in upravljanjem v izobraževanju in drugimi vedami (Blažič idr., 2003). Preučevanje izobraževalne tehnologije temelji na ameriški tradiciji, ki je vplivala na razvoj izobraževalne tehnologije v Evropi (ibid.). Skozi razvoj je bilo področje izobraževalne tehnologije povezano $s$ teorijami učenja in teorijami poučevanja, $v$ evropski tradiciji pa še $z$ didaktičnimi teorijami. $Z$ razvojem računalništva in informacijske tehnologije na to področje vplivajo tudi računalništvo, umetna inteligenca, načrtovanje sistemov, interakcija človek-računalnik (Issroff in Scanlon, 2002, str. 4) in druge družboslovne in humanistične discipline, ki preučujejo tehnologijo v družbi.

$\mathrm{V}$ tradiciji Združenih držav Amerike (ZDA) vpliva na področje izobraževanja pedagoška psihologija s teorijami učenja in poučevanja. Te so vplivale tudi na izobraževalno tehnologijo, ki se je razvijala kot samostojno področje. Pod vplivom kognitizma, ki razvija modele poučevanja, so začeli tudi izobraževalno tehnologijo obravnavati skupaj z modeli poučevanja, nastalimi v okviru teorij poučevanja (Reiser, 2001b). Reiser opiše dve praksi, ki ju zajema izobraževalna tehnologija in po zaslugi katerih se je $\mathrm{v}$ sedemdesetih letih uveljavil pojem načrtovanje poučevanja in tehnologije (angl. instructional design and technology): uporabo tehnologije $\mathrm{v}$ izobraževalne namene in uporabo sistematičnih postopkov oblikovanja učnega procesa (Reiser, 2001a). Oblikovanje in vrednotenje kurikula in učenja ter reševanje problemov pri njuni vpeljavi in izboljševanju je jedro izobraževalne tehnologije tudi v britanski tradiciji (Rowntree, 1982). 
Izobraževalna tehnologija je bila sprva omejena na obrobno vlogo pripomočkov, učil in sredstev. Pod vplivom komunikacijskih teorij je bila pojmovana kot nosilec ali posredovalec informacij (Blažič idr., 2003). Pod vplivom kognitivnih teorij učenja in poučevanja se je obravnavi pripomočkov pridružila obravnava načrtovanja in izvajanja procesov (Reiser, 2001a). Pri opredelitvi pojma izobraževalna tehnologija ločimo dva vidika: vidik rabe tehnologije kot tehničnega pripomočka in vidik vpliva tehnologije na oblikovanje učnega procesa. Izobraževalna tehnologija izhaja iz dveh osnovnih podmen:

- tehnične možnosti, ki jih prinaša neka tehnologija, in

- na kakšen način se tehnične možnosti uporabljajo.

Vpeljava izobraževalne tehnologije rešuje dve temeljni nalogi, omogoča posodabljanje izobraževanja skladno s tehnološkim napredkom in izboljšanje procesov poučevanja in učenja. Tehnološki razvoj in inovacije na področju tehničnih možnosti omogočajo spremembe na področju poučevanja in učenja. Razvoj inovacij na področju izobraževalne tehnologije in njihovo sprejemanje med učitelji, vzgojitelji in učenci je pogojeno $z$ dejavniki formalnih in neformalnih procesov učenja. Načini širjenja inovacij in njihovega sprejemanja med končnimi uporabniki so se z razvojem informacijsko-komunikacijskih tehnologij (IKT), ki so omogočile nove načine komunikacije, spremenili. Za starejša obdobja značilna proliferacija, ki označuje hitro širjenje v vseh družbenih okoljih in sistemih, se v obdobju družbenih omrežij in mobilne tehnologije dopolnjuje s perkolacijo, ko s širjenjem tehnologije poteka izmenjava (pronicanje) praks med različnimi okolji in sistemi.

Naj na primeru rabe analognih tehnologij v primerjavi z digitalnimi ponazorimo pojmovni vidik uporabe pojma izobraževalna tehnologija, ki zadeva tehnološki vidik in vidik oblikovanja procesov učenja.

Digitalno pripovedovanje zgodb zajema tehnološki vidik, ki zadeva izdelavo in predstavitev zgodbe, kot tudi vse didaktične značilnosti analognega načina tradicionalnega pripovedovanja zgodb. Zato ga moramo preučevati v tehnološkem in didaktičnem pogledu.

Pripovedovanje zgodbe v kurikulu zasledimo pri jeziku in književnosti, zgodovi$\mathrm{ni}$, likovni in glasbeni vzgoji. Digitalno pripovedovanje zgodb na ravni priprave in 
vključevanja v učni proces združuje didaktične vidike, ki so uveljavljeni na omenjenih področjih z novimi tehnološkimi možnostmi. Tehnologija prinaša tudi nove možnosti, kot so denimo klepetalnice, spletne učilnice in spletna družbena omrežja. Njeni predhodnici sta bili radijska šola in televizijske učne ure, za katere je bil značilen daljinski prenos. Temeljni prispevek današnjih spletnih družbenih omrežij je v vnašanju novih možnosti oblikovanja učnega procesa.

Izobraževalna tehnologija je sprva zajemala materialni del in imela vlogo pripomočkov, učil in sredstev. Pod vplivom komunikacijskih teorij je bila pojmovana kot nosilec ali posredovalec informacij (Blažič idr., 2003). V obeh omenjenih obdobjih je bila v didaktiki vključena med strukturne sestavine vzgojno-izobraževalnega procesa (Kramar, 2009). Pod vplivom kognitivnih teorij učenja in poučevanja se je obravnavi pripomočkov pridružila obravnava načrtovanja in izvajanja procesov (Reiser, 2001a). Izobraževalna tehnologija prepleta dva vidika: vidik rabe tehnologije kot strukturne sestavine in vidik oblikovanja učnega procesa (procesne sestavine).

$\mathrm{V}$ predšolskem obdobju $\mathrm{v}$ literaturi beležimo manj intenzivno uporabo pojma izobraževalna tehnologija. K temu prispevata dve dejstvi. Predšolski kurikul temelji na igri kot otrokovi primarni aktivnosti. V igri otrok vzpostavlja interakcijo in uporablja različne digitalne tehnologije - artefakte v svojem neposrednem okolju. V predšolskem obdobju je primarno okolje družina in predšolska vzgoja v vrtcu poteka v tesnem partnerstvu s starši. Na področju zgodnjega učenja je v literaturi razširjena uporaba digitalne tehnologije, ki pokriva široko paleto digitalnih naprav, vsebin, iger in igrač, ki jih otrok uporablja v domačem okolju in okolju vrtca, medtem ko v kurikulu zasledimo uporabo informacijsko komunikacijske tehnologije. Drugo pomembno dejstvo so opredelitve otroške igre in njenih funkcij. Otroška igra je avtotelna dejavnost, pri kateri se otrok igra zaradi igre same in se pri igri uči in razvija. Digitalna tehnologija po ugotovitvah raziskave med starši in vzgojitelji, ki so jo izvedli Plowman, McPake in Stephen (2010; 2012), prispeva k učenju in razvoju na tri poglavitne načine: (1) Razvija spretnosti za razumevanje funkcionalnosti in interaktivnosti digitalnih medijev kot tudi sposobnosti za otrokovo manipulacijo le-teh. (2) Širi znanje in razumevanje sveta na različnih kurikularnih področjih ob uporabi programov, spletnih strani in digitalnih knjig. (3) Razvija dispozicije za učenje na afektivnem, socialnem in kognitivnem področju (Plowman, McPake in Stephen, 2012). 


\section{Izobraževalna tehnologija za razvoj kompetenc 21. stoletja}

Med ključnimi kompetencami za 21. stoletje so pomembni trije sklopi kompetenc. Prvi sklop tvorijo kompetence za življenje in kariero, drugi sklop kompetence za učenje in inoviranje (komunikacija, sodelovanje, ustvarjalnost, kritično mišljenje - angl. 4C: Creativity, Critical thinking, Communication and Collaboration), v tretji sklop pa so uvrščene informacijske, medijske in tehnološke kompetence (P21 2010; 2012). Trilling in Fadel (2009) med kompetence za 21. stoletje uvrščata kritično mišljenje in reševanje problemov, ustvarjalnost in inoviranje, medkulturno razumevanje, komunikacijsko, informacijsko in medijsko pismenost, računalništvo in IKT-pismenost, karierno in učno samozaupanje (angl. 7C: Critical thinking and problem solving, Creativity and innovation, Cross-cultural understanding, Communications, information and media literacy, Computing and ICT literacy, Career and learning self-reliance).

Izobraževalna tehnologija je povezana z vsemi sklopi kompetenc:

- informacijskimi, medijskimi in tehnološkimi kompetencami;

- uporabo različnih orodij za komunikacijo in sodelovanje, kritično mišljenje in ustvarjalnost, kar vpliva na kompetence za učenje in inoviranje;

- vzpostavljanjem učnega okolja za razvoj kompetenc za življenje in delo.

Informacijske, medijske in tehnološke kompetence lahko obravnavamo v okviru različnih oblik pismenosti. UNESCO je denimo opredelil medijsko in informacijsko pismenost za učitelje z vključitvijo sestavin informacijske, medijske, računalniške, internetne, digitalne in medijske pismenosti (Wilson, Grizzle, Tuazon, Akyempong in Cheung, 2013).

Računalniško mišljenje je Janette Wing leta 2006 opredelila kot reševanje problemov, oblikovanje sistemov in razumevanje človeškega obnašanja na podlagi temeljnih pojmov računalništva (Wing, 2006). Avtorica je spodbudila vključevanje računalniškega mišljenja v kurikul obveznega izobraževanja celotne populacije (Barr, Harrison in Conery, 2011). Seymour Papert (1980) je v svojem pionirskem delu 
Mindstorms na podlagi Piagetove (1962) razvojne teorije utemeljil računalniško mišljenje in njegov prispevek k razvoju spretnosti reševanja problemov. Barr s soavtorji opredeli računalniško mišljenje kot proces reševanja problemov, ki obsega formulacijo problemov ob podpori uporabe računalnika in drugih orodij, organizacijo in analizo podatkov, reprezentacijo podatkov $\mathrm{z}$ modeli in simulacijami, algoritmično mišljenje ter posploševanje in prenos procesa reševanja problemov na različna področja (Barr, Harrison in Conery, 2011). Računalniško programiranje vključuje poznavanje računalniških pojmov, praks in perspektiv, ki učencem pomagajo razumeti sebe, družbo in tehnologijo (Wing, 2008; Lye in Koh, 2014). Spodbuja razvoj sposobnosti za ravnanje s kompleksnimi nalogami, vztrajnost pri težavnih nalogah, toleranco pri nejasnih nalogah, sposobnost reševanja problemov z odprto rešitvijo ter sposobnost komunikacije in sodelovanja pri doseganju ciljev (Barr, Harrison in Conery, 2011).

$\mathrm{V}$ drugem sklopu kompetenc učenja in inoviranja je model $4 \mathrm{C}$ zelo blizu taksonomiji izobraževalne tehnologije, ki sta jo na podlagi Deweyjevega (1943) modela otrokove interakcije z okoljem podala Bruce in Levin (1997). Taksonomija obsega štiri vrste izobraževalne tehnologije, in sicer za: (1) učenje z odkrivanjem ali raziskovanjem, (2) komunikacijo, (3) konstrukcijo, (4) ustvarjanje (ibid.).

Začetke izobraževalne tehnologije zaznamuje avdiovizualna komunikacija in uporaba naprav za prenos učnih vsebin. Računalniško podprto poučevanje in inteligentni tutorski sistemi so bili sprva usmerjeni $v$ individualnega učenca. $V$ devetdesetih letih prejšnjega stoletja se je z razvojem interneta (Stahl, Koschmann in Suthers, 2006) in pod vplivom konstruktivizma za spodbujanje v študenta osredinjenega učenja (Means in Olson, 1997) razširilo računalniško podprto sodelovalno učenje. Uporaba računalnika pri učenju je prešla zgolj usmerjenost na posameznika. Računalniško podprto sodelovalno učenje spaja prednosti skupinske oblike učenja, $v$ interakcijskem trikotniku učna vsebina - učenec - učenec, ob uporabi raznovrstnih sodelovalnih tehnologij, učnih virov in učnih metod. Skupinsko učenje uresničuje načelo individualizacije ob izkoriščanju vplivov na socialno-afektivnem področju učenja, $v$ interakciji med učenci (Strmčnik, 1987). Učenje poteka $v$ socialni interakciji in $\mathrm{v}$ interakciji s kulturnimi artefakti $\mathrm{v}$ družbeno-kulturnem okolju (Vigotsky, 1987). Sodelovalno učenje opredeljuje soodvisnost študentov pri uresničevanju ci- 
ljev vseh posameznikov in skupine (Johnson in Johnson, 1996) in skupno spoznavanje in učenje (Resnick, 1993).

Računalniško podprto sodelovalno učenje je leta 2017 še vedno osnovna izobraževalna tehnologija (Adams Becker, Cummins, Davis, Freeman, Hall Giesinger in Ananthanarayanan, 2017) in tudi osnovna strategija pri izobraževanju učiteljev za uporabo izobraževalne tehnologije (Hattie, 2009; Tondeur, van Braak, Siddiq in Scherer, 2016; Hao in Lee, 2017). Računalniško podprta učna okolja spodbujajo ustvarjalnost in kritično mišljenje (Istenič Starčič in Lebeničnik, 2020). Iz raziskav v zadnjem desetletju 20. stoletja je razviden koristen prispevek izobraževalne tehnologije na vseh kurikularnih področjih in tudi njen vpliv na razvoj otroka in njegovih sposobnosti ustvarjalnega in kritičnega mišljenja ter na socialni razvoj in učenje učenja (Clements, Nastasi in Swaminathan, 1993; Clements, 1999; Yelland, 2005).

\section{Pomen digitalne in medijske pismenosti}

B. Street pri opredelitvi razvojnih vidikov pismenosti in pedagoških pristopov $\mathrm{k}$ pismenosti izpostavi štiri tradicije: pismenost in učenje; kognitivni pristop k pismenosti; pristop, ki pismenost obravnava umeščeno v socialnih praksah; in pismenost kot besedilo (Street, 2005). Pri učenju in poučevanju pismenosti je opozoril na prehod od pojmovanja pismenosti v kontekstu spoznavnih procesov k socialno-kulturnim razumevanjem pismenosti. Pismenost se pojmuje v okviru kognitivnega pristopa kot neodvisna entiteta, ki se poučuje neodvisno od kontekstov kot nevtralna za uporabo v različnih kontekstih. Medtem ko socialno-kulturno razumevanje pismenost umešča v avtentične kontekste različnih družbeno-kulturnih praks in jo pojmuje kot družbeno opredeljeno in ne neodvisno od razmerij moči v družbi, kar je značilno za »avtonomni model « v okviru kognitivnega pristopa. Avtonomni model pismenost pojmuje kot vrsto spretnosti, orodij, tehnik in kognitivnih kompetenc, ki se jih posameznik nauči in mu bodo omogočile delovanje v različnih kontekstih (Street, 1989; 2005).

Že Vigotski (1978) je pedagoške intervencije poučevanja in učenja pismenosti postavil $v$ družbeno-kulturne kontekste, kjer se pismenost razvija $v$ avtentičnih praksah. Z Bernes-Leejevim konceptom svetovnega spleta in intenzivno proliferacijo in 
rastjo različnih spletnih storitev se je konec prejšnjega stoletja začela širitev družbeno-kulturnih praks na internetu. S porastom digitalnih vsebin na internetu se je tudi opredelitev pismenosti iz primarnega branja in pisanja razširila na (1) tvorjenje in razbiranje vsebin na različne reprezentacijske načine, ki vključuje (2) raven kodifikacije $z$ operacionalnimi in tehničnimi kompetencami in (3) epistemično raven vsebinske interakcije $\mathrm{z}$ vsebinami, ki poteka v družbeno-kulturnih praksah.

V obdobju intenzivnega razvoja različnih tehnologij in medijev je spremenjena narava komunikacije in pojmovanja pismenosti, tradicionalno vezane na uporabo medija pisave (Buckingham, 2015). D. Buckingham opredeli pismenost onkraj izvirnega pojmovanja, ki je bilo vezano na uporabo medija pisave. Pismenost je obravnavana kot porajajoča se pismenost, ki se razvija $\mathrm{v}$ otrokovi igri z mediji (Spencer, 1986, v Buckingham, 2015), vizualna pismenost (Moore in Dwyer, 1994, v Buckingham, 2015), televizijska pismenost (Buckingham, 1993, v Buckingham, 2015), informacijska pismenost (Bruce in Levin, 1997, v Buckingham, 2015).

Pismenost ni avtonomna entiteta (Street, 1989; 2015), zanjo je značilna raznolikost pojavnosti (Buckingham, 2015) v različnih družbeno-kulturnih in tehnoloških razmerah in terja sodobne pedagoške pristope (Cope in Kalantzis, 2000). Marsh s sodelavci opredeli pismenost kot digitalno pismenost, saj ne zadeva več le pisave in poteka ob uporabi vrste digitalnih tehnologij ob dogodkih in praksah, ki vključujejo tako online kot offline aktivnosti (Sefton-Green, Marsh, Erstad in Flewitt, 2016; Marsh, Hannon, Lewis in Ritchie, 2017). Izobraževalna tehnologija je povezana s tretjim sklopom kompetenc za 21. stoletje, ki obsegajo informacijske, medijske in tehnološke kompetence (P21 2010; 2012).

Informacijske, medijske in tehnološke kompetence so obravnavane v sklopu informacijske, medijske in digitalne pismenosti. Pojmovane so bile na podlagi koncepta avtonomne pismenosti, kot jo je opredelil Street (1989), postopno so vključevale več dimenzij in se tudi medsebojno prepletale in dopolnjevale. Novejša nizozemska opredelitev digitalne pismenosti povezuje IKT-spretnosti, medijsko pismenost, informacijsko pismenost in računalniško mišljenje in se v nacionalnem kurikulu izvaja integrirano $\mathrm{z}$ avtentičnim učenjem in preverjanjem (Fisser, Heitink in Strijker, 
2020). Pismenost in razvoj pismenosti zahtevata družbeno-kulturni kontekst in umeščenost, v kateri se izgrajuje smisel (Street, 2005).

Opredelitve informacijske pismenosti so v sedemdesetih letih vključevale iskanje in pridobivanje informacijskih virov, reševanje problemov in uporabo informacij $v$ različnih situacijah. V osemdesetih so se s širitvijo računalnika poudarili različni viri in različne tehnologije, ki omogočajo pridobivanje informacij in pomen kritičnega vrednotenja informacij. $\mathrm{V}$ devetdesetih se je opredelitev, ki vključuje iskanje, kritično vrednotenje in uporabo informacij, ustalila. $V$ tem času so bila izrazita gibanja za vključevanje različnih informacijskih virov v izobraževanje in razvijanje informacijske pismenosti, ki omogoča kakovostno učenje s pestrimi viri. Izražene so bile zahteve za vključevanje informacijske pismenosti med ključne sestavine pismenosti (Behrens, 1994).

Medijska pismenost je $\mathrm{v}$ devetdesetih letih opredeljena kot kritično branje informacij in medijskih vsebin ter vključuje medije, ki so se pojavili za tiskom (Bawden, 2001). Bawden (ibid.) pojmuje medijsko pismenost kot prekrivajočo se z informacijsko pismenostjo in še predvsem z eno izmed njenih definicij, ki jo je podal Hamelink (1976, v Bawden, 2011) in se bistveno razlikuje od drugih opredelitev. Hamelink (ibid.) je informacijsko pismenost namreč opredelil kot zmožnost neodvisnega mnenja in presojo medijskih vsebin in potrebo po neodvisnosti medijev od političnih vplivov. R. Hobbs (1999) že konec devetdesetih let povzame ključna vprašanja medijske pismenosti, med njimi (1) vlogo medijske pismenosti za varnost otroka, ki jo otrok razvija z dejavnim udejstvovanjem v medijskih razpravah; (2) otrokovo vlogo producenta in ne zgolj potrošnika, ki se odraža tudi pri učnih aktivnostih produkcije medijskih vsebin; (3) vlogo popularne kulture pri razvoju medijske pismenosti kot kulturno umeščene prakse; (4) ideološkost kurikula medijske pismenosti; (5) enakost pri zagotavljanju medijske pismenosti vsem otrokom; (6) vlogo medijskih organizacij pri razvoju pismenosti in prikritem kurikulu.

Iz opredelitev lahko razberemo socialno-kulturno razumevanje pismenosti, kot jo opredeljuje Street (2005). Pri raziskovanju in razvoju medijske pismenosti kot večdimenzionalnega pojma so pomembna spoznanja medijskih študij, sociologije, psihologije, pedagogike, zdravstva, bibliotekarstva in informacijskih študij. Za me- 
dijsko pismenost je ključna obravnava $\mathrm{v}$ različnih kontekstih: $\mathrm{v}$ kontekstu kritičnega državljana in uporabnika medijskih vsebin, v kontekstu otrokovega razvoja, z vplivom medijskih vsebin na procese socializacije ter v kontekstu profesionalnega dela, ki vse bolj vključuje internet in računalniška orodja (Hobbs, 2017). Hobbs (2011) med spretnostmi digitalne pismenosti našteje tehnične, kognitivne, medijske in socialne spretnosti. Tudi Potter (1998) opredeli medijsko pismenost večdimenzionalno. Obsega kognitivno, čustveno, estetsko in moralno dimenzijo. Opredelitev medijske pismenosti iz leta 1992 izpostavlja kritično branje medijev in medijskih vsebin, ki sloni na petih točkah: mediji so konstruirani in konstruirajo resničnost, imajo tržne, politične in ekonomske učinke, medijska oblika in vsebina sta povezani z estetskim in sporočevalnim kodom, vsak bralec sporočilo tudi interpretira (Aufderheide, 1992).

Digitalna pismenost se je pojavila v devetdesetih letih (Bawden, 2001). Gilster je leta 1997 opredelil digitalno pismenost kot spretnost uporabe interneta, ki v primerjavi s tiskanimi mediji predstavlja vsebine v nadbesedilu in $v$ različnih oblikah, in informacijsko pismenost $s$ kritičnim branjem informacij. Opredelil je štiri kompetence: pridobivanje znanja, vrednotenje vsebin, iskanje po internetu in navigacija nadbesedila (Gilster, 1997). V Glisterjevi opredelitvi sta prisotni epistemična in reprezentacijska dimenzija.

Sodobna obravnava digitalne pismenosti zajema dve podmeni: (1) konceptualizacijo digitalne pismenosti v procesu odmika od tehnološkega in informacijskega vidika k socialnim praksam in (2) transformacijo izvirne pismenosti z medijem pisave, ki se transformira v večkodno pismenost in večrazsežnostno pismenost, to je sestavljeno pismenost $\mathrm{v}$ družbenih praksah.

Spremljamo konceptualizacijo digitalne pismenosti kot pismenosti, ki razumevanje medijev kot tehnološkega ali informacijskega (Buckingham, 2015) transformira v razumevanje medijev kot socialne prakse (Sefton-Green, Marsh, Erstad in Flewitt, 2016). Opredelitev informacijske pismenosti izpostavlja z razvojem informacijske družbe kritično vrednotenje in uporabo zbranih informacij (Behrens, 1994). Tehnološka opredelitev računalniške pismenosti (Fetler, 1985), ki pomeni tehnično uporabo računalniške tehnologije in njene aplikacije, je v kurikulu vodila v razvoj 
tehnoloških pojmov, spretnosti uporabe tehnologije, programiranje, računalniško mišljenje in reševanje problemov. Langhorne, Donham, Gross in Rehmke (1989) pojem računalniške pismenosti razširijo in opredelijo $s$ tremi sestavinami: znanjem o računalniku, uporabo aplikacij (urejevalnik besedila, baze podatkov, preglednice, grafike, namizno založništvo, glasba, računalniško podprto učenje) in znanjem s področja socialnega konteksta, povezanega z uporabo računalnika (avtorske pravice, pravica do zasebnosti, vpliv tehnologije na življenje v prihodnosti, zavedanje o informacijski družbi).

Razvoj digitalne tehnologije omogoča poleg potrošnje medijskih vsebin tudi produkcijo (Jenkins, Clinton, Purushothm, Robinson in Weigel, 2007) in vpliva na sodobno pismenost, ki ne poteka več zgolj z uporabo tradicionalnega medija pisave (Buckingham, 2015). Pri tem so pomembne porajajoče se prakse v družbeno-kulturnih kontekstih, ki izkoriščajo naravo digitalne tehnologije, ta pa omogoča večkodno oblikovanje besedil in večkodno pismenost (Kress in van Leuween, 2001; Kress in Jewitt, 2003). Pismenost v povezavi s praksami branja in pisanja ne zadeva več le pisave, temveč vključuje večkodno izražanje (Marsh idr., 2017). Opredelitev večkodne pismenosti se nanaša na medije in semiotična sredstva, reprezentacija in komunikacija sta večkodni (Kress, 2003). Računalniška tehnologija omogoča večkodne reprezentacije in komunikacije (Debevc, Weiss, Šorgo in Kožuh, 2020) in s tem vpliva na mišljenje (Kress in Jewitt, 2003).

$\mathrm{V}$ teh razmerah stopa $\mathrm{v}$ ospredje misel, ki pismenost obravnava kot dinamično in odvisno od vsakokratnega družbeno-kulturnega konteksta. Večrazsežnostna ali sestavljena pismenost, ki je ob uporabi dinamičnih reprezentacijskih virov ves čas živa in spreminjajoča se v družbeno-kulturnih kontekstih uporabnikov, zajema različne družbeno-kulturne prakse uporabnikov $\mathrm{v}$ njihovih avtentičnih kontekstih (New London Group, 2000). Tehnološki razvoj omogoča pojavljanje novih oblik besedil, ki na različne načine sestavljajo ločljive oblike pismenosti (na primer besedno, besedilno, vizualno, digitalno, multimedijsko) in omogočajo različne načine interakcije in sodelovanja (Grosman, 2011).

Marsh, Hannon, Lewis in Ritchie (2017) raziskujejo pismenost kot prakse branja in pisanja, ob uporabi različnih digitalnih tehnologij, ki podpirajo različne kode, 
in ne zgolj pisavo. Sefton-Green, Marsh, Erstad in Flewitt (2016) digitalno pismenost opredeljujejo kot prakse branja, pisanja in osmišljanja ob uporabi vrste digitalnih tehnologij, ki potekajo ob dogodkih in praksah, ki vključujejo tako online kot offline aktivnosti. Digitalna pismenost prečka fizične meje in meje online/offline ter vzpostavlja kompleksno komunikacijo izven časa in prostora (Lander in Sheehy, 2004). Digitalna pismenost zajema digitalno tvorjenje besedil, razvoj spretnosti tvorjenja besedil pa poteka v različnih družbeno kulturnih praksah (Lankshear in Knobel, 2008; 2011).

Pedagogika večrazsežnostne ali sestavljene pismenosti opredeli pismenost kot umeščeno v družbeno-kulturnih praksah, ki jih sovzpostavljajo internet in digitalne prakse (New London Group, 2000). Ob šolski pismenosti postaja pomembno preučevanje praks pismenosti, ki se razvijajo izven šolskega konteksta, denimo doma in v vrstniških skupinah, in njihovo vključevanje v šolski kurikul (Lankshear in Knobel, 2008; Lankshear in Knobel, 2011). Otrokova porajajoča se pismenost v družinskem okolju poteka v interakciji z različnimi internetnimi viri (Plowman, Stephen in McPake, 2010a).

Uporaba digitalnih virov za branje in tvorjenje elektronskih besedil s prostorsko usmerjenostjo in visoko stopnjo sestavljenosti (besednih, vizualnih in drugih podatkov), ki nadomešča in spreminja bralčevo/piščevo linearno interakcijo z besedilom, pogojuje pismenost, govorno-jezikovni razvoj in procese vzgoje in izobraževanja (Grosman, 2011). S kompleksnejšim pojmovanjem pismenosti je v formalnem učnem okolju utemeljena potreba po poučevanju in učenju pismenosti, ki vključuje vse oblike razbiranja in tvorjenja besedil, v povezovanju raznovrstnih formalnih in neformalnih družbenih praks (Grosman, 2011).

\section{Dejavniki uporabe izobraževalne tehnologije}

Za uporabo izobraževalne tehnologije pri zgodnjem učenju so med ključnimi dejavniki digitalna pismenost in spretnosti vzgojiteljev (Hatzigianni in Kalaitzidis, 2018). Razvoj digitalnih spretnosti in uporaba digitalne tehnologije sta odvisna od pojmovanja in stališča učiteljev o uporabnosti izobraževalne tehnologije (Istenič Starčič in Lebeničnik, 2020). Pojmovanja in stališča so med najmočnejšimi napove- 
dniki uporabe izobraževalne tehnologije (Ertmer, Ottenbreit-Leftwich, Sadik in Sendurur, 2012). Raziskovalci preučujejo pripravljenost za uporabo nove tehnologije z merjenjem posameznikove percepcije o uporabnosti tehnologije oziroma o tem, koliko lahko tehnologija izboljša posameznikovo delovanje (Davis, 1989; Venkatesh, Morris, Davis in Davis, 2003) in vpliva na organizacijo in izvedbo učiteljevega/vzgojiteljevega dela (Valenčič Zuljan in Marentič Požarnik, 2014; Istenič Starčič, 2019; Istenič Starčič in Lebeničnik, 2020). Na področju izobraževanja med stališči o uporabnosti tehnologije in njenem prispevku preučujejo: stališča o vplivu na izboljšanje učenja in dosežkov, stališča o vplivu na individualizacijo in diferenciacijo, stališča o vplivu na spodbujanje ustvarjalnosti (Sang, Valcke, van Braak in Tondeur, 2010), vidljivost posameznikovega dela in dosežkov, omogočanje novih aktivnosti, ki pred uporabo tehnologije niso bile mogoče, in prilagodljivost aktivnosti (Van Braak in Tearle, 2007). Na oblikovanje pojmovanj in stališč pomembno vpliva začetno izobraževanje vzgojiteljev in učiteljev (Drent in Meelissan, 2008).

Leta 2006 je po poročilu finske raziskave digitalna pismenost učitelja in vzgojitelja zajemala tri ravni uporabe informacijsko-komunikacijskih tehnologij. Na prvi ravni spretnost uporabe urejevalnikov besedil in e-pošte, na drugi ravni naprednejše pedagoško poznavanje razvoja učnih virov ter na tretji, najvišji ravni, ki jo je dosegalo le 10 odstotkov pedagoških delavcev, uporabo multimedije, sistemov za izobraževanje na daljavo, mreženje, programiranje, uporabo administrativnih sistemov in uporabo informacijsko-komunikacijske tehnologije za raziskovanje in inoviranje. (Ristimaki, Niemi, Tissari, Mikkola in Jakku-Sihvonen, 2006)

$S$ tehnološkim razvojem in dostopnostjo tehnologije je postala tretja raven osnovna za vse pedagoške delavce. $Z$ odmikom od tradicionalne tehnologije pisave $\mathrm{k}$ digitalni tehnologiji je osnovna skrb učitelja/vzgojitelja v kontekstu razvoja pismenosti tudi razvoj digitalnih spretnosti v (Istenič Starčič in Turk, 2016). Na 25. konferenci Svetovnega spleta, ki je potekala v Montrealu, sta avtorja predstavila model digitalne pismenosti $v$ treh dimenzijah (Slika 2), ki sta ga oblikovala na podlagi treh uveljavljenih modelov (Mishra in Koehler, 2006; Puentedura, 2012; Koole, 2009).

Model digitalnih kompetenc učitelja vključuje tehnološko, pedagoško in vsebinsko predmetno specifično znanje (model TPV), ki sta ga razvila Mishra in Koe- 
hler (2006), in zajame tehnološke intervencije skladno z modelom NOSO (Puentedura, 2013) (Slika 1). Model NOSO (Nadomeščanje, Obogatitev, Spreminjanje, Opredelitev) (Puentedura, 2012) predlaga vključevanje tehnologije za izboljševanje in spreminjanje pouka. Tehnologija se v učne aktivnosti lahko vključuje na štirih različnih stopnjah:

- za nadomeščanje obstoječe aktivnosti,

- za obogatitev obstoječe aktivnosti,

- za spreminjanje aktivnosti,

- za ponovno opredelitev aktivnosti, ki pred tehnološko vpeljavo ni bila mogoča.

Slika 1: Vključevanje izobraževalne tehnologije po modelih TPV (Mishra in Koehler, 2006) in NSO (Puentedura, 2013)

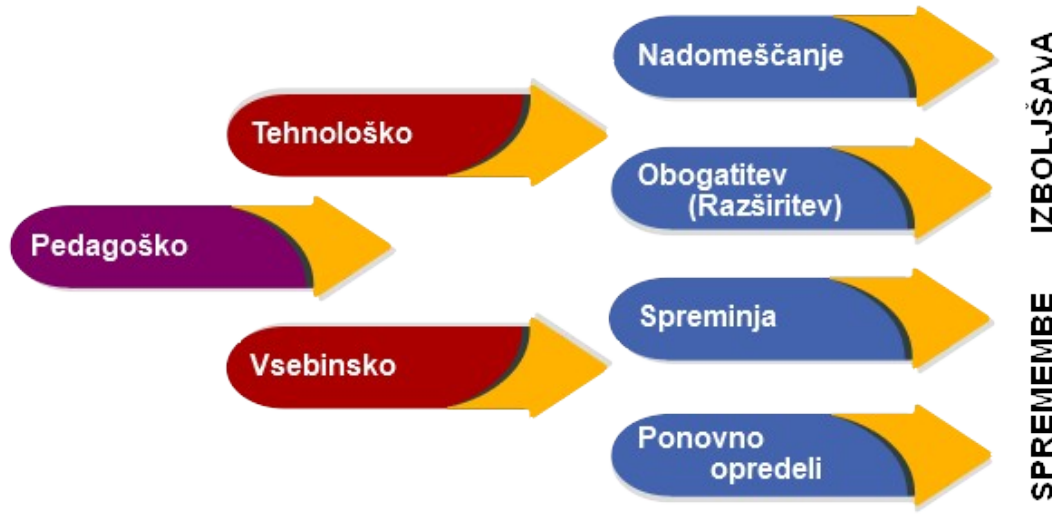

Model za relacijsko analizo mobilnega izobraževanja (Koole, 2009) vključuje uporabnika, mobilno napravo in socialno interakcijo. Vključevanje tehnologije (naprava) spodbuja otrokov razvoj (značilnosti učenca) in učenje ob povezovanju tradicionalnih aktivnosti pri delu s tradicionalnimi materiali in viri (socialno okolje). Vzgojitelj načrtuje vključevanje tehnologije tako, da ne okrni naravnega in tradicionalnega okolja, ki je za otrokovo učenje in razvoj pomembno. Hkrati upošteva otrokovo življenjsko prakso s tehnologijo in jo vključuje tako, da prispeva k učenju na 
kognitivnem, socialno-afektivnem in psihofizičnem področju učenja. Koole je model razvil na podlagi otrokovega območja aktualnega razvoja (Vigotski, 1978). Vzgojiteljeva naloga je podpirati otroka pri kakovostni uporabi tehnologije, ki spodbuja otrokov razvoj. $V$ preseku med napravo in socialnim okoljem so značilnosti, ki izhajajo iz obeh dimenzij in odražajo zmožnosti naprave v socialnem kontekstu. $V$ preseku med dimenzijama naprave in otroka so značilnosti otroka, ki izhajajo tudi iz socialnega okolja in se odražajo v uporabi naprave.

Načrtovanja ne podredimo učnim ciljem, ki bi bili dekontekstualizirani od otrokove življenjske prakse in razmišljanja. Pri načrtovanju usmerimo pozornost na otrokove sposobnosti in interese, ki mu doseganje učnih ciljev osmislijo v kontekstu njegovega življenjskega sveta (presek dimenzij otroka in socialnega konteksta). Pri načrtovanju priprave na pouk s procesom kognitivne empatije poskušamo proces razmišljanja učencev čim bolj osvetliti. Učitelj naj predvideva odzive in ravnanje učencev (Cerbin in Kopp, 2006).

Unesco je leta 2010 podal didaktična priporočila za vključevanje IKT pri zgodnjem učenju z opisom vzgojiteljevih kompetenc v treh sklopih (spoznavanje, učenje, integracija). Didaktična priporočila obsegajo: integracijo digitalnih igrač in izobraževalnih programskih aplikacij za otroke; načrtovanje in spremljanje razvoja otrok pri uporabi IKT za izražanje pri igri in učenju; vključevanje IKT za uresničevanje učnih ciljev na vseh področjih učenja, razumevanje vloge IKT pri zgodnjem učenju in izobraževanju; razumevanje potencialov za otrokov razvoj in profesionalni razvoj vzgojitelja. Vzgojiteljeve kompetence za vključevanje IKT v vrtcih vključujejo: (1) spoznavanje tehnologije, (2) učenje s tehnologijo in (3) integracija tehnologije v pedagoškem delu. Spoznavanje tehnologije zadeva razvoj kompetenc za delo z besedilom, multimedijo, risanje in barvanje. Učenje za IKT vključuje uporabo kompetenc za dejavno sodelovanje in učenje v okolju svoje vzgojno-izobraževalne organizacije in v širšem okolju. Vključevanje tehnologije pri pedagoškem delu v vrtcu sledi porajajoči se digitalni pismenosti otroka (Kalaš, 2010). 
Slika 2: Dimenzije digitalne pismenosti učitelja/vzgojitelja

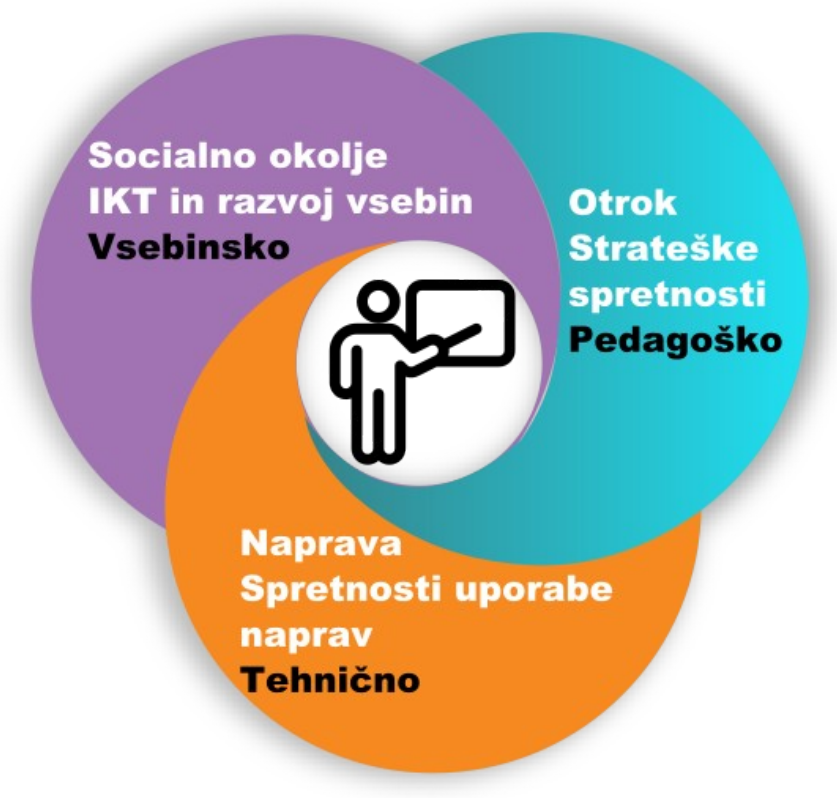

Uveljavljen model digitalnih kompetenc vključuje učiteljeve profesionalne in pedagoške kompetence in razvoj učenčevih digitalnih kompetenc (Redecker, 2017). Kompetence predstavlja v treh sklopih (Slika 3): (1) profesionalne kompetence (komunikacija, sodelovanje, refleksivna praksa, digitalno profesionalno učenje), (2) pedagoške kompetence za poučevanje in učenje (poučevanje, vodenje in usmerjanje, sodelovalno učenje, samoregulativno učenje), digitalni viri (izbor, oblikovanje, upravljanje, varnost in deljenje), opolnomočenje učencev (diferenciacija in personalizacija, dostopnost in inkluzija, aktivno vključevanje učencev), preverjanje in ocenjevanje (strategije preverjanja, analiza rezultatov, povratna informacija in načrtovanje) in (3) razvoj digitalnih kompetenc učencev (informacijska in medijska pismenost, komunikacija, razvoj vsebin, odgovorna uporaba, reševanje problemov). 
Slika 3: Digitalne kompetence učitelja/vzgojitelja (Redecker, 2017)

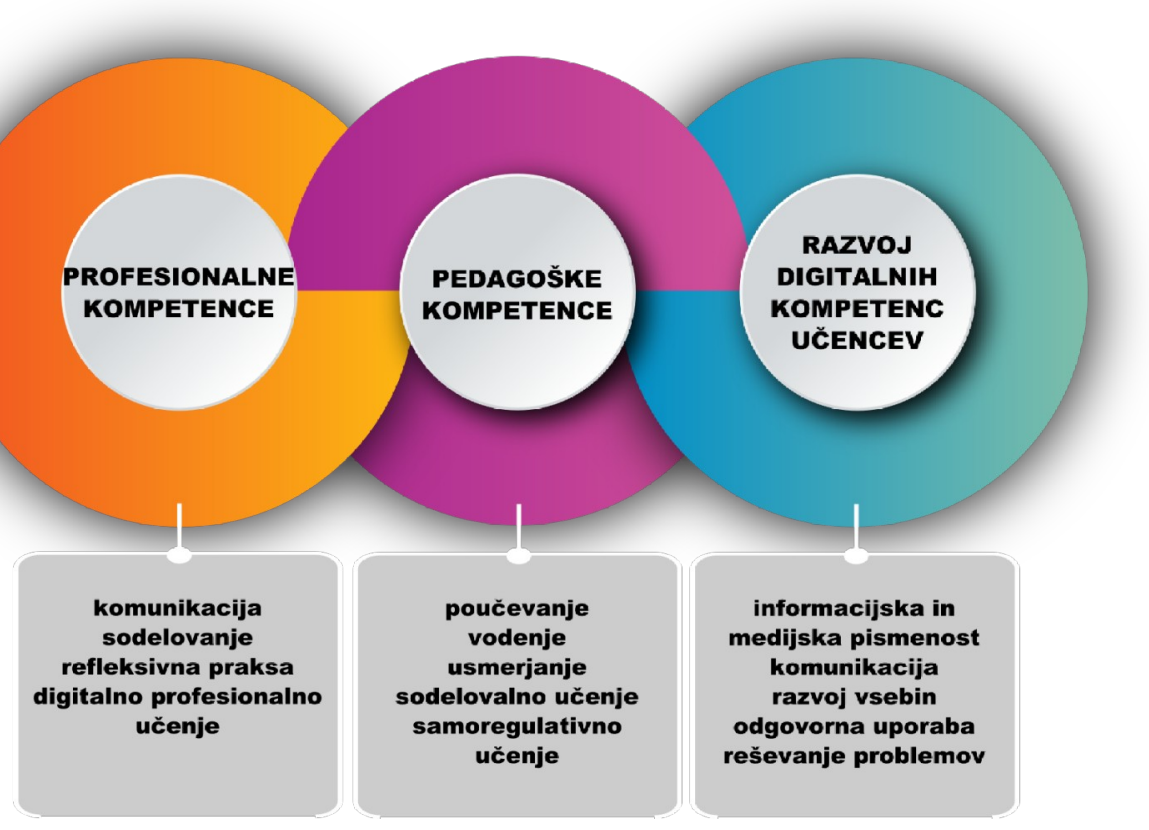




\section{Izobraževalna tehnologija v vzgojno-izobraževalnem procesu}

M. Kramar opredeli vzgojno-izobraževalni proces kot »... namerno načrtno, družbeno organizirano dejavnost, $v$ kateri udeleženci izobraževanja $\mathrm{z}$ različnimi aktivnostmi dosegajo postavljene vzgojno-izobraževalne cilje ...«(Kramar, 2009). Med nalogami vzgojno-izobraževalnega procesa so materialne, formalne in formativne naloge. Materialne naloge obsegajo razvoj materialnega ali snovnega znanja, formalne naloge obsegajo razvijanje sposobnosti in osebnostnih lastnosti, formativne naloge zadevajo razvoj celovite osebnosti. Izpostavitev trojnosti nalog je pomembna pri načrtovanju in izvedbi vzgojno-izobraževalnega procesa, saj se pri vsakem delovanju učenca in učitelja prepletajo procesi v okviru treh področij učenja: kognitivni, socialno-afektivni in psihomotorični (Kramar, 2009). Na načrtovanje izobraževalne tehnologije vplivajo teorije učenja (Blažič idr., 2003) in teorije poučevanja. Teorije učenja preučujejo in razlagajo procese in dejavnike, ki vplivajo $\mathrm{v}$ procesih učenja ter obravnavajo spremembe $\mathrm{v}$ posameznikovem delovanju in pogoje $\mathrm{v}$ katerih je do sprememb prišlo (Driscoll, 2000).

Avtorji v ZDA postavljajo razvoj področja izobraževalne tehnologije v zgodnje 20. stoletje z vizualnimi in avdiovizualnimi pripomočki pri pouku (Reiser, 2001b). Izobraževalna tehnologija je bila v prvih dveh desetletjih 20. stoletja osredinjena na vizualizacijo v okviru gibanja za vizualizacijo pri pouku, v obdobju razvoja prvih izobraževalnih filmov (Reiser in Ely, 1997). Vizualni pripomočki so bili namenjeni podpori učiteljevemu poučevanju. Uporabo vizualnih gradiv in orodij pri pouku so v 20. stoletju po zaslugi tehnoloških inovacij zvočnega snemanja, radia in gibljive slike z zvokom dopolnili avdiovizualni viri in pripomočki (Reiser in Ely, 1997). Že v času gibanja za vizualizacijo pouka je bilo izpostavljeno, da ne gre le za pripomočke pri učiteljevem poučevanju, vizualna gradiva in pripomočki imajo namreč v kurikulu enakovredno vlogo ob učbenikih in učiteljevem poučevanju (Reiser in Ely, 1997). V didaktičnem trikotniku, učitelj - učenec - učna vsebina se didaktična sredstva umestijo kot četrta komponenta, učitelj - učenec - učna vsebina - didaktična sredstva (Kramar, 2009). 
$\mathrm{V}$ petdesetih in zgodnjih šestdesetih letih pride s komunikacijsko revolucijo in razvojem komunikacijskih teorij do prehoda s preučevanja avdiovizualnih gradiv in pripomočkov pri poučevanju na preučevanje avdiovizualne komunikacije in medijev (Reiser, 2001b) na oblikovanje sporočila ob uporabi različnih medijev v pedagoškem procesu (tiskanega, filmskega, radijskega, televizijskega, računalniškega). Menili so, da področje pokriva več kot zgolj vire in pripomočke, ter začeli preučevati komunikacijske teorije pri razvoju in uporabi avdiovizualnih pripomočkov in virov (Reiser in Ely, 1997). Področje izobraževalne tehnologije je bilo v šestdesetih letih opredeljeno kot avdiovizualna komunikacija, ki se ukvarja z načini oblikovanja in posredovanja sporočil pri usmerjanju procesa učenja (ibid.). V sedemdesetih letih so področje avdiovizualnega poučevanja in komunikacije nadomestili s širšim področjem - načrtovanje poučevanja in tehnologije (angl. instructional design and technology) (Reiser, 2001b). Tudi samo poimenovanje profesionalnega združenja v ZDA se je v sedemdesetih letih spremenilo iz Oddelka za avdiovizualno poučevanje (Department of Audiovisual Instruction - DAVI) v Združenje za izobraževalno komunikacijo in tehnologijo (Association for Educational Communications and Technology - AECT) (ibid.).

Pred prvo uradno opredelitvijo leta 1963 je bila izobraževalna tehnologija umeščena v okviru avdiovizualnega poučevanja. $V$ šestdesetih letih je bila izobraževalna tehnologija obravnavana v okviru avdiovizualne komunikacije (Reiser in Ely, 1997; Reiser, 2001b). Teorije poučevanja razvijajo modele poučevanja, ki temeljijo na teoriji učenja in v procesu učenja omogočajo opredelitev pogojev in učinkov učiteljevih intervencij in podpore (Smith in Regan, 1996). V sedemdesetih letih se pod vplivom kognitivizma in razvoja teorij poučevanja področje preimenuje v načrtovanje poučevanja in tehnologije (Reiser, 2001b). Obravnava se premakne iz usmerjenosti na učno vsebino in reprezentacijske značilnosti vizualnih in zvočno-vizualnih elementov v vzgojno-izobraževalni komunikaciji k oblikovanju učnega procesa in učinkovitost tehnologij pri učenju glede na zastavljene učne cilje in metode. Kognitivna teorija je imela večji vpliv na izobraževalno tehnologijo konec sedemdesetih in v osemdesetih, čeprav so pomembna dela nastala že v petdesetih in šestdesetih letih. Kognitivna teorija prenese pozornost $\mathrm{z}$ učnih rezultatov (učno ciljna usmerjenost) na proces učenja (procesna usmerjenost) in značilnosti učencev ter razlike med njimi. Ko- 
nec sedemdesetih let se na področju izobraževalne tehnologije začne uveljavljati načrtovanje učenja po modelih učenja, kar pomeni premik od komunikacijskih značilnosti sredstev $\mathrm{k}$ načrtovanju procesa učenja.

$\mathrm{V}$ osemdesetih letih se je, z razširitvijo mikroračunalnikov in informacijsko-komunikacijskih tehnologij, računalnik v izobraževanju dodobra uveljavil. V začetnem obdobju, ki je trajalo od petdesetih ali šestdesetih do osemdesetih let, so se z računalnikom ukvarjali strokovnjaki s specialističnim računalniškim znanjem programiranja. V začetnem obdobju so vključevali računalnik v izobraževanje za individualizacijo pouka $s(1)$ sistemi vadenja, (2) z računalniško podprtimi učnimi enotami (ki obsegajo, besedilo, diagrame, animacije), (3) s simulacijskimi sistemi (modeli resničnega sveta, eksperimenti), (4) z orodji za učenje (za obdelavo podatkov, laboratorijsko delo), (5) z učenjem programiranja (tudi programiranjem kot reševanjem problemov in računalniškim mišljenjem) (Jones, Kirkup in Kirkwood, 1992). Vpeljava računalnika $v$ izobraževanje je podpirala procese vodenja in upravljanja ter poučevanja in učenja (Ramiszowski, 1988), računalniško podprti učni viri so bili poleg sistemov za računalniško podprt pouk med ključnimi zmožnostmi pri zgodnji vpeljavi računalnika (Reynolds in Anderson, 1992).

$\mathrm{Z}$ razvojem interneta $\mathrm{v}$ devetdesetih letih tudi na področje izobraževanja prodirajo omrežja. Intenziven tehnološki razvoj na področju računalništva in BernessLeejev koncept svetovnega spleta vzpostavita možnosti sodelovanja in široko dostopnost virov. Omogočeni so samodirektivno učenje ob uporabi učnih virov, odprta učna okolja (Hannafin Land in Oliver, 1999) in računalniško podprto sodelovalno učenje. $\mathrm{V}$ tem obdobju je vpliven konstruktivizem s procesno usmerjenostjo in na učenca osredinjenim učenjem.

$\mathrm{S}$ tehnološkim razvojem in vpeljavo računalnika izobraževalna tehnologija ni več pojmovana zgolj v okviru didaktičnih sredstev (v okviru strukturnih sestavin), s svojimi zmožnostmi podpira namreč celoten izobraževalni proces, na strukturni in procesni ravni. Sodobna digitalna tehnologija obsega elektronska orodja, sisteme, naprave in vire, omogoča hranjenje in obdelavo podatkov (Victoria state government education and training, 2019). 
V strukturi vzgojno-izobraževalnega procesa je bila izobraževalna tehnologija umeščena med strukturnimi sestavinami (Kramar, 2009), sedaj pa jo opredelimo v sklopu strukturnih in procesnih sestavin učnega procesa, ki zadeva stopnje artikulacije vzgojno-izobraževalnega procesa z vidika učitelja in učencev (Slika 4).

Slika 4: Struktura vzgojno-izobraževalnega procesa

\section{Izobraževalna tehnologija kot vezni člen}

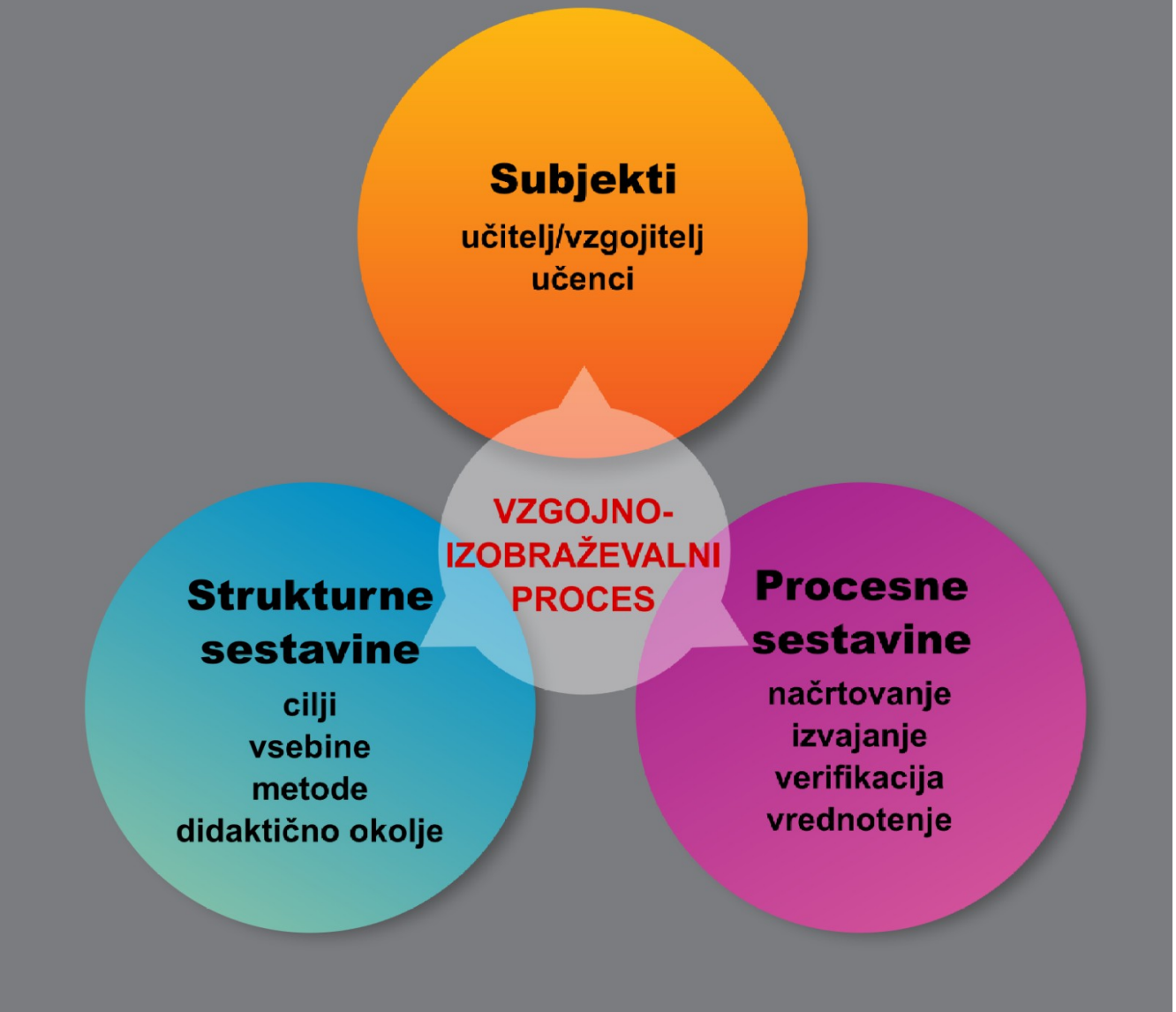

V vzgojno-izobraževalnem procesu je vloga izobraževalne tehnologije obravnavana v globalni shemi dejavnikov, saj ima izobraževalna tehnologija pomembno vlogo pri povezovanju poučevanja $\mathrm{v}$ vzgojno-izobraževalnih zavodih in učenja $\mathrm{v}$ narav- 
nih okoljih. Poučevanje ima namreč podlago v učenju v različnih naravnih okoljih (Strmčnik, 2001). Pri vzpostavljanju učnega okolja, ki omogoča učenje, povezano z naravnimi okolji, z izvirnimi problemi in kulturnimi praksami, ima pomembno vlogo izobraževalna tehnologija. Izobraževalna tehnologija omogoča vzpostavljanje avtentičnega učnega okolja na tri pomembne načine: (1) uporaba digitalne tehnologije je za današnje generacije avtentična dejavnost in avtentično okolje socialnega življenja, (2) zaradi zmožnosti sodobne tehnologije se lahko avtentična učna okolja vzpostavljajo s povezovanjem učilnice in različnih izvirnih okolij (naravnih in drugih) in (3) učno okolje z vsemi funkcijami se lahko vzpostavi v različnih izvirnih okoljih.

Izobraževalna tehnologija podpira avtentično učenje na treh ravneh: (1) učenje, povezano $\mathrm{z}$ avtentičnim življenjskim okoljem, (2) učenje, povezano $\mathrm{z}$ avtentičnimi življenjskimi nalogami, in (3) učenje, povezano z značilnostmi učenca in njegovo interakcijo v okolju. Omogoča približevanje naravnega okolja vzgojno-izobraževalnemu procesu (simulacije, virtualna resničnost), vzpostavljanje vzgojno-izobraževalnega procesa v naravnem okolju (mobilno učenje) in vzpostavljanje učnega okolja, ki omogoča avtentične naloge in upošteva izvirne značilnosti učencev.

$\mathrm{Na}$ predšolski stopnji omogoča izobraževalna tehnologija avtentično učenje, ki ga Dewey (1938) opredeli kot učenje, ki je otroku smiselno. Na podlagi Deweyevega (1943) modela otrokove interakcije z okoljem sta Bruce in Levin (1997) izobraževalno tehnologijo $v$ predšolskem kurikulu, temelječem na otrokovi izvirni dejavnostiigri, razvrstila $\mathrm{v}$ štiri kategorije: (1) učenje z odkrivanjem in raziskovanjem kot otrokovo osnovno motivacijo, (2) komunikacija kot osnovna oblika socialnega udejstvovanja, (3) konstrukcija, ki poteka od besednega izražanja prek igre v gibanju in oblikovanju z različnimi materiali, in (4) ustvarjanje (Bruce in Levin, 1997). V predšolskem vzgojno-izobraževalnem procesu izobraževalna tehnologija podpira otrokovo izvirno ustvarjalno dejavnost, ki je pogoj otrokovega razvoja in je prilagojena njegovim nagnjenjem (odkrivanje, interakcija, reševanje, oblikovanje, ustvarjanje). V okviru prve kategorije izobraževalna tehnologija za učenje z odkrivanjem in raziskovanjem obsega široko paleto orodij za razširitev čutil, za razmišljanje in manipuliranje s podatki. V okviru druge kategorije izobraževalna tehnologija za komunikacijo obsega sklop orodij za oblikovanje sporočil, interakcijo in sodelovanje. V okviru tretje kategorije izobraževalna tehnologija za konstrukcijo obsega sklop orodij za oblikova- 
nje. V okviru četrte kategorije izobraževalna tehnologija za ustvarjanje obsega sklop orodij za likovno, glasbeno, multimedijsko izražanje, animacijo in kompozicijo (Bruce in Levin, 1997).

\section{Izobraževalna tehnologija v globalnem sistemu dejavnikov vzgojno- izobraževalnega procesa}

Pri obravnavi dejavnikov vzgojno-izobraževalnega procesa in dejavnikov uporabe izobraževalne tehnologije bomo za širši okvir uporabili shemo ekološke sistemske teorije Bronfenbrennerja (1979) in socialno-kulturne teorije Vigotskega (1978). Pri pojasnjevanju nam najbolje služi pojem prakse, ki v sociološki teoriji prakse integrira, manifestira in vzpostavlja človekovo dejavnost in socialne strukture in sisteme (Ortner, 1984). Prakse sovzpostavljajo različne sisteme (na primer družino, šolo). Značilnosti prakse so razumljivost znotraj posameznih praks ter postopki dejavnosti in sporazumevanja (ibid.). Pri načrtovanju izobraževalne tehnologije so pomembne prakse uporabe digitalne tehnologije $\mathrm{v}$ družini in med vrstniki. Bronfenbrennerjev $(1979 ; 1986)$ model preučevanja otroka znotraj mikrookolja njegove družine in v soodvisnosti mikro- in mezosistemov ter makrosistema in njihovih praks je neposredno uporaben pri preučevanju otrokovih digitalnih praks. Socialno-kulturna teorija Vigotskega (1978) obravnava otroško igro v odnosu do družbeno-kulturnega okolja, v katerem so digitalne tehnologije kulturno orodje.

Uporaba digitalne tehnologije spreminja družinske, šolske in medvrstniške prakse na dva načina, s proliferacijskim širjenjem in s svojo vsenavzočnostjo. $V$ preteklosti smo govorili o proliferacijskem širjenju tehnologije, ki označuje hitro širjenje v družbenih praksah. Za šolske prakse je bilo značilno zaostajanje za drugimi praksa$\mathrm{mi}$, tehnologije so se pri učenju in poučevanju vpeljevale počasneje in z zamudo. V zadnjem desetletju govorimo o perkolacijski širitvi, ko s širjenjem tehnologije potekata izmenjava in pronicanje med različnimi praksami (Istenič Starčič in Lebeničnik, 2020).

Tehnologija je vsenavzočna in vzpostavlja okolja onkraj časovnega, geografskega ali fizično opredeljenega prostora. Tehnološko okolje opredeljujejo tehnološke zmožnosti oziroma interakcija, ki v teh okoljih poteka (Plowman, 2016). Tehnologija postaja neopazna in je prodrla v vse pore družbenega življenja. Raziskovalci opozar- 
jajo na neustreznost izolirane obravnave tehnologije znotraj družinske ali šolske prakse kot preddeterminiranega okolja (ibid.). Če je bila tehnologija nekoč vidno umeščena znotraj doma in so prakse ravnanja z njo zadevale, denimo, okolje družine, postaja danes tehnologija vse bolj neopazna in vzpostavlja kontekst onkraj družinskega okolja (ibid.). Preučevanje se preusmerja iz preučevanja okolja, »kjer potekajo prakse uporabe tehnologije«, na preučevanje z zajemom vsebine praks oziroma preučevanje, »kaj tehnološke prakse zajemajo v okolju družine in onkraj« (ibid.).

V obdobju širjenja televizije so bile jedro raziskovanja medijske vsebine, njihove reprezentacijske oblike in učinki na otrokov razvoj in učenje. Kasneje je preučevanje zajemalo vpliv časa, preživetega pred zasloni, in kolonizacijo prostega časa na račun drugih družinskih prostočasnih aktivnosti, vpliv prikazovanja nasilja, izkoriščanje otroštva za spodbujanje potrošništva (Wartella in Robb, 2011) in razvoj popularnih kultur, ki so z digitalno tehnologijo spremenile otroško igro in obvladujejo otroške medijske prakse (Cook, 2005).

$\mathrm{Z}$ razvojem televizije se je razširila uporaba televizije $\mathrm{v}$ izobraževalne namene. Televizijske oddaje za otroke so bile oblikovane na osnovi kurikularnih ciljev in predvajane v okviru formalnega učenja, priporočenega s strani vzgojno-izobraževalnih ustanov $\mathrm{v}$ televizijskih programih $\mathrm{z}$ namenom formalnega in neformalnega učenja $\mathrm{v}$ otrokovih prostočasnih aktivnostih. Raziskovalci so preučevali vpliv televizije na otrokovo učenje (Barr in Hayne, 1999). V zgodnjem obdobju otroštva lahko televizijske otroške izobraževalne oddaje spodbudno vplivajo na kognitivne sposobnosti (Ball in Bogatz, 1970), jezikovne sposobnosti (Rice in Haight, 1990) in prosocialne spretnosti (Stein in Friederich, 1975). Preučevali so vpliv različnih televizijskih vsebin na razvoj kognitivnih sposobnosti in usvajanje znanja (Solomon in Cohen, 1977) in različnih kombinacij video, zvočnih in govornih vsebin ter dinamike (hiter ali počasen tempo) na usvajanje znanja (Huston in Wright, 1983). V študijah so opozorili na senzorične značilnosti televizije. Te po intenzivnosti presegajo ugodje, ki ga otrok občuti pri branju, gledanju slikanic in spontani domišljijski igri in posledično vpliva na otrokove prakse (Singer, 1981). Preučevali so, kako otrokovo gledanje televizije vpliva na otrokovo spontano domišljijsko igro. Singer (ibid.) med poglavitnimi značilnostmi našteje pozornost, kratke sekvence in učinek interference. Televizija pritegne največ otrokove pozornosti in ga odvrača od drugih aktivnosti. 
Intenzivna dinamika kratkih sekvenc vpliva na otrokovo dojemanje in doživljanje, kajti otrok ǐšce podobno intenzivnost dražljajev tudi drugje. Učinek interference z intenzivnim predvajanjem zunanjih reprezentacij vpliva na otrokov spomin in predelavo informacij. Otrok predeluje zunanje dražljaje in zaznavo z lastno domišljijo, vokalizacijo besed ali zvokov in z motoričnim gibanjem. Pri gledanju televizije zre v zaslon in zaradi hitre dinamike dogajanja lastne zaznave ne more predelati, kar okrni njegovo doživljanje in domišljijski svet, ki sta osnova otrokove domišljijske igre (ibid.).

Preučevanje družinskega okolja in aktivne vloge staršev se je konceptualiziralo ob pojmu starševske mediacije, ki opredeljuje aktivno vlogo staršev in njihove načine posredovanja med otrokom in mediji. Teorija starševske mediacije se je ukvarjala $s$ preučevanjem negativnih medijskih učinkov na otrokovo obdelavo informacij in kognitivni razvoj (Clark, 2011).

Preučevanje se je iz medijskih vsebin in medijskih učinkov preusmerilo na preučevanje tehnologije kot okolja in z njim povezanega doživljanja na kognitivni, socialno-afektivni, psihomotorični in senzorični ravni. Socialno-kulturna teorija obravnava otroško igro v odnosu do družbeno-kulturnega okolja, v katerem so digitalne tehnologije kulturno orodje (Vigotski, 1978). Skozi igro kot avtotelno dejavnost (igra sama po sebi vzrok in namen) otrok že v zgodnjem obdobju doživlja svoje družbenokulturno okolje, ga interpretira z domišlijo (Vigotski, 1978). Pri igri uporablja kulturna materialna orodja, med katera spada digitalna tehnologija. Psihološka orodja, znak, govor in drugi simbolni sistemi pripomorejo k razvoju kognitivnih procesov, ki se razvijajo ob uporabi različnih kulturnih materialnih orodij v interakciji otroka $\mathrm{z}$ okoljem (Vigotski, 1978).

$\mathrm{V}$ družbi in kulturi so digitalne tehnologije pomemben izvor družbeno-kulturnih praks na vseh področjih, tudi pri interakciji v družini, šoli in med vrstniki. Raziskovalci na področju izobraževanja preučujejo digitalne tehnologije kot jedro družbeno-kulturnih vsebin in orodij ter z njimi povezanih praks (Plowman, Stevenson, Stephen in McPake, 2012; Edwards, 2013). Z digitalnimi tehnologijami povezani praksi potrošništva in popularne kulture pronicata v otroške prakse. Otroška igra in igrače se izrabljajo za prefinjene načine oglaševanja. Otrokove potrebe po igračah so 
medijsko konstruirane $\mathrm{z}$ elementi popularne kulture. Otrok se sreča $\mathrm{z}$ igračami $\mathrm{v}$ televizijskih oddajah, filmih, nadaljevankah in v računalniških igrah.

Sodobni pojav konceptualizacije igrače poteka s transmedijskim pripovedovanjem zgodb skozi različne medijske kanale in oblike, denimo risanko, film, računalniško igro (Gulden, 2015; Jenkins, 2003). Pametne igrače povezujejo online in offline, virtualno in fizično okolje (Marsh, 2010), povezane igrače zbirajo podatke o družini, ki jih proizvajalec analizira za oglaševanje svojih produktov.

Uporaba digitalnih tehnologij pri otroški igri in učenju je odziv na družbenokulturni kontekst, v katerega so tehnologije integrirane (Edwards, 2013). Oblikujejo naravo interakcije v družbi, družini, šoli ter med vrstniki. Digitalna tehnologija kot orodje spoznavanja in učenja je v socialno-kulturni teoriji Vigotskega (1978) vključena $v$ otroško igro in šolske prakse od vrtca dalje. Igra manifestira družbeno-kulturne prakse, značilne za digitalne tehnologije.

Raziskovalci govorijo o vse bolj zabrisani meji med domom, šolo in tehnološkim okoljem (Plowman, 2016). Tehnologija je bila v preteklosti obravnavana znotraj družine ali šole, denimo delež izpostavljenosti medijskim vsebinam, in se je osredinila na merjenje vpliva na otrokov razvoj. Pri preučevanju tehnologije kot okolja obravnavamo vzpostavljanje kontekstov, ki jih opredeljuje tehnološko okolje, in niso omejeni na družino ali šolo. Tehnološko okolje je vsenavzočno in stalno prisotno ter brezšivno vstopa v različne družbene prakse. Zapoveduje svoje lastne prakse komunikacije in interakcije med ljudmi in tehnološkimi napravami, značilnimi za različne tehnološke prakse.

Okolje ni več prostorsko ali časovno določeno in postaja $\mathrm{z}$ vsenavzočno tehnologijo brezmejno, vodi nas v nove pristope pri razmišljanju o odnosih med praksami, ljudmi in tehnologijo (ibid.). Potrebna je drugačna zastavitev obravnave tehnologije v vsakdanjem življenju otroka in mladostnika. Preučevanje otrokove in mladostnikove uporabe tehnologije poteka $\mathrm{v}$ kontekstu, ki ni vezan na neposredno prostorsko ali časovno opredeljeno okolje. Obravnava se premakne od preučevanja neposrednega okolja k obravnavi konteksta, ki je vzpostavljen s tehnološkim okoljem in ni vezan na neposredno prisotno krajevno in časovno opredeljeno okolje (ibid.). Za tehnološko okolje so značilne prakse, ki jih opredeljuje prostorska in časovna razširjenost, 
celo brezmejnost, razdrobljenost in razpršenost ter brezšivno vključevanje v različne prakse družine ali šole.

Opredelitev digitalne pismenosti, ki so jo podali Sefton-Green, Marsh, Erstad in Flewitt (2016), odraža kontekstualno dimenzijo, ki sega onkraj časa in prostora. Digitalno pismenost opredeljujejo kot prakse branja, pisanja in osmišljanja ob uporabi vrste digitalnih tehnologij, ki potekajo ob dogodkih in praksah z vključevanjem tako online kot offline aktivnosti. Digitalna pismenost prečka fizične meje in meje med online in offline ter vzpostavlja kompleksno komunikacijo izven časa in prostora (Lander in Sheehy, 2004, v Sefton-Green, Marsh, Erstad in Flewitt, 2016).

Pri obravnavi otrokove aktivnosti doma ali pri druženju z vrstniki je uporaba mobilnega telefona in računalnika vezana na kontekste izven neposrednega okolja. Obravnava otrokove aktivnosti nujno vključuje otrokovo interakcijo v neposrednem okolju in v kontekstih, vzpostavljenih s tehnološko podprto interakcijo, ki vodi $\mathrm{v}$ prepletanje interakcije $\mathrm{v}$ neposrednem in virtualnem okolju. Brišejo se meje med realnim in virtualnim, med offline in online aktivnostmi (Marsh, 2010; Plowman, 2016).

\section{Izobraževalna tehnologija v strukturi vzgojno-izobraževalnega procesa}

V didaktični teoriji dejavniki vzgojno-izobraževalnega procesa sestavljajo kompleksen sistem subjektov, ki delujejo v kontekstu oddelka, vrtca, družine, v lokalnem okolju in na globalni ravni družbenih in naravnih sistemov. Izobraževalni proces je strukturna in procesna celota, ki jo sestavljajo: subjekti (učitelj/vzgojitelj, učenci), strukturne sestavine (cilji, vsebine, metode, didaktična sredstva, didaktično okolje) in procesne sestavine (artikulacija vzgojno-izobraževalnega procesa: načrtovanje, izvajanje, verifikacija in vrednotenje) (Kramar, 2009).

Obravnava osnovne strukture pouka je tradicionalno potekala $\mathrm{v}$ didaktičnem trikotniku v odnosu med tremi komponentami: učitelj/vzgojitelj - učenec - vsebina. $V$ drugi polovici 20. stoletja, v didaktični teoriji, ta trikotnik dopolnijo z didaktičnimi sredstvi in ga tako razširijo v štirikomponentno strukturo učitelj - učenec vsebina - didaktična sredstva (ibid.). V slovenski didaktiki med strukturne sestavine 
štejemo cilje, vsebine, metode, didaktična sredstva in didaktično okolje, medtem ko učitelja/vzgojitelja in učence obravnavamo med subjekti pouka (ibid.).

Izobraževalna tehnologija je v slovenski didaktiki pojmovana kot strukturna sestavina. V opredelitvah strukture pouka slovenskih didaktikov zasledimo didaktična sredstva. Kramar (ibid.) opredeli didaktična sredstva kot vire, prenosnike (medije) in delovanje učiteljev in učencev. Iz pregleda opredelitve in zgodovinskega razvoja pojma izobraževalne tehnologije je razvidno, da je prešla več faz, začenši z vsebino in njeno vizualizacijo oziroma zvočno-vizualno predstavitvijo v prvih desetletjih 20. stoletja. Že tedaj je bilo opozorjeno, da imajo v kurikulu vizualna gradiva in orodja enakovredno vlogo, in sicer ob učbenikih in učiteljevem poučevanju (Reiser in Ely, 1997). Zatem je bila pojmovana v okviru vzgojno-izobraževalne komunikacije, podprte z različnimi tehnologijami, ki s svojimi značilnostmi omogočajo posredovanje vzgojno-izobraževalnih sporočil (Ely, 1983; Reiser, 2001b). V zadnjem obdobju se razprava premakne $\mathrm{k}$ učnemu okolju, ki ga vzpostavlja izobraževalna tehnologija (Istenič Starčič in Lebeničnik, 2020) kot strukturna in procesna sestavina. V sedemdesetih letih je bila namreč $\mathrm{z}$ razvojem modelov poučevanja $\mathrm{v}$ okviru teorije poučevanja opredeljena kot načrtovanje poučevanja in tehnologije (Reiser, 2001b) in zajema strukturne in procesne sestavine.

Izobraževalno tehnologijo zato opredelimo $\mathrm{v}$ sklopu strukturnih in procesnih sestavin, ki omogočajo artikulacijo vzgojno-izobraževalnega procesa s strani učitelja/ vzgojitelja in učencev.

$\mathrm{V}$ nadaljevanju obravnavamo strukturne sestavine, učno okolje in učne cilje. $\mathrm{V}$ uvodu smo že opozorili na vpliv tehnološkega razvoja in na kontekstualno pojmovanje učnega okolja. Pri uporabi izobraževalne tehnologije je pomembna obravnava v povezavi z digitalnimi tehnologijami v otrokovem družinskem okolju, ki ni omejena na fizično okolje doma. Digitalna tehnologija posega v družinsko okolje z vnosom družbeno-kulturnih praks potrošništva in množičnih kultur s posebnimi praksami, značilnimi za tehnološka okolja. Med njimi so denimo igrače z vključevanjem različnih medijskih kanalov in oblik, kot so risanka, film, računalniška igra in didaktična igra in delujejo transmedijsko. 


\section{Otrokovo primarno okolje in digitalna tehnologija}

Za otrokov razvoj od rojstva do šole je pomembno primarno okolje družine $\mathrm{z}$ aktivno vlogo staršev. $\mathrm{V}$ družbeno-kulturne prakse družine $\mathrm{v}$ neposrednem fizičnem okolju s socialno interakcijo, otrokovo igro in artefakti se vključuje digitalna tehnologija, ki vpliva na otrokove vsakodnevne izkušnje. Otrokova primarna interakcija v družinskem okolju je spremenjena na dva načina. Digitalna tehnologija poseže v razmerje med otrokom, interakcijsko vsebino in okoljem, s čimer spremeni interakcijo $\mathrm{v}$ družini s spreminjanjem konteksta, v katerem otrok vzpostavlja interakcijo. Kot je zapisala Plowmanova (2016), otrok ni v interakciji v neposrednem prostorsko in časovno določenem domačem okolju, interakcijski kontekst mu vzpostavlja tehnološko okolje. Spremenjena sta tudi način in proces interakcije med otrokom in starši ter drugimi družinskimi člani. Digitalna naprava se pojavi kot vmesnik interakcije v družinskem okolju, ki interakcijo lahko zavira ali pa omogoča nove načine komunikacije. Na primer, ob gledanju v zaslon se starši pogovarjajo z otrokom brez očesnega stika in s tem siromašijo komunikacijo očesnega stika. Ta je ključna za otrokovo čustveno varnost in osnovna spodbuda za njegovo izražanje in interakcijo $\mathrm{z}$ odraslim. Ob igranju z digitalno igračo ali igranjem zaslonske igre otroci vstopajo $\mathrm{v}$ teh nološka okolja, ki vzpostavljajo kontekst izven družinskega okolja.

\section{Trendi preučevanja vpliva digitalnih tehnologij v otrokovem okolju}

Preučevanje družinskih digitalnih praks in otrokove izpostavljenosti medijem je postalo intenzivno s širitvijo televizije. $S$ proliferacijo televizije $v$ domove otroci že pred tretjim letom starosti redno gledajo televizijske oddaje in imajo pri starosti dveh let svoje priljubljene oddaje (Guernsey, 2012). Preučevanje otrokove uporabe informacijsko-komunikacijskih tehnologij je z razširitvijo televizije problematiziralo vpliv množičnih medijev in medijskih vsebin (Wartella in Robb, 2011), predvsem negativnih učinkov na otrokovo obdelavo informacij in kognitivni razvoj (Clark, 2011). Med njimi Wartella in Robb (2011) izpostavita: preučevanje vpliva časa, preživetega pred zasloni, kolonizacijo prostega časa na račun drugih družinskih prostočasnih aktivnosti, vpliv prikazovanja nasilja in potrošništvo, ki nagovarja starše posredno preko otrok. Omenjenemu je treba dodati preučevanje popularnih kultur, ki se širijo z 
digitalno tehnologijo in spreminjajo otroško igro. Potrošništvo in popularne kulture vstopajo v otroške medijske prakse (Cook, 2005). Uporabo digitalne tehnologije je izredno težko ločevati od potrošnje. Uporaba digitalne tehnologije omogoča potrošnjo, potrošnja pa spodbuja uporabo tehnologije (Edwards, 2013).

Zaradi produkcije programov za otroke (Anderson in Pempek, 2005) in prisotnosti več televizijskih naprav v gospodinjstvu, ki so tudi v otroških sobah, se je podaljšal čas, ki ga otroci preživijo pred zasloni (Wartella in Robb, 2011). Leta 2003 je imelo v ZDA skoraj 40 odstotkov otrok, mlajših od šest let, v sobi televizijo (Wartella in Robb, 2011). V obdobju vsenavzočnosti mobilnih naprav in uveljavljanja tabličnih računalnikov in pametnih telefonov ima vse več otrok v lasti mobilne naprave, kar njihov čas pred zasloni še podaljšuje, znižuje se starost otrok, ki preživljajo čas pred zasloni. Preučevanje vplivov medijskega nasilja nad otrokom (Bandura, 1977; Singer, 1981) se je od preučevanja prvotnega gledanja televizije razširilo na vse digitalne medije. Preučevanje zajema vrsto pojavov: gledanje nasilja v medijskih vsebinah, igranje nasilnih računalniških iger, prikazovanje različnih oblik odnosnega nasilja, kot so zlorabe prijateljstva in nasilna sporočila. Raziskovalci ugotavljajo, da medijsko nasilje učinkuje na predstave otrok in pozneje odraslih o različnih družbenih pojavih in posledično na odnose, ki jih razvijejo v krogu družine, vrstnikov in kasneje v delovnem okolju.

Razvoj potrošništva in popularnih kultur je pospešila televizija z vključevanjem oglaševanja $\mathrm{v}$ oddaje za otroke in $\mathrm{v}$ osemdesetih letih z razvojem tržnih oddaj, ki so promovirale igrače (Wartella in Robb, 2011). Razvoj digitalnih medijev je potrošništvo še pospešil, saj le-to ni več časovno in prostorsko določeno z obiskom trgovine. Uporaba digitalne tehnologije pa tudi že vključuje različne oblike potrošništva. Otroške igrače in drugi izdelki spadajo med stebre potrošništva. Otroška igra in igrače se prefinjeno tržijo $\mathrm{z}$ razvojem igrač kot t. i. spinoff izdelkov medijske produkcije (televizijskih serij, filmov, računalniških iger) in pametnih igrač, kjer zbirajo podatke o družinskih praksah, kar industriji omogoča pospeševanje potrošnje.

Preučevanje vplivov medijev v družinskem okolju se je konceptualiziralo ob preučevanju starševske mediacije. Clark (2011) iz obdobja televizije povzema tri strategije starševske mediacije: aktivno mediacijo kot pogovor o medijih $\mathrm{z}$ otrokom, re- 
striktivno mediacijo kot postavljanje pravil, ki regulirajo otrokovo uporabo medijev, in skupno gledanje, ki obsega predvsem navzočnost in neverbalno komunikacijo. Aktivna mediacija s pogovorom spodbuja interakcijo med starši in otrokom na splošno, razvija pri njem kritično mišljenje in kritično evalvacijo medijskih vsebin (ibid.). Raziskave so restriktivno mediacijo postavile pred skupno gledanje, medtem ko premalo restriktivna ali preveč restriktivna mediacija $\mathrm{v}$ otroku zbudi odpor in željo do prepovedanega (Nathanson, 2002, v Clark, 2011). Skupno gledanje televizije kot družinska praksa, ki združuje družinske člane, je bilo deležno kritike, češ da je družina le fizično združena pred televizijskim zaslonom, kar pa ne spodbuja in povečuje interakcije med družinskimi člani (Maccoby, 1951, v Wartella in Robb, 2011). Ameriška akademija pediatrov je leta 1999 opozorila na nevarnost nadomeščanja neposredne interakcije v družini s pasivnim gledanjem televizije (AAP - American Academy of Pediatrics, 1999). Nekatere raziskave pa so ugotovile tudi pozitivne učinke na družinsko počutje in strukturiranje družinskih rutin glede na televizijski program (Silverstone, Hirsch in Morley, 1991; Lull, 1980, v Clark, 2011). Raziskave poročajo o razlikah med spoloma, materjo in očetom, po izobrazbi in razlikah glede na družinske dohodke. Matere, višje izobraženi starši in družine z višjim dohodkom uporabljajo več strategij starševske mediacije (Eastin, Greenberg in Hofshire, 2006, v Clark, 2011).

Z lastništvom mobilnih naprav in njihovim vstopom $\mathrm{v}$ otroške sobe postaja starševska mediacija zahtevnejša. $Z$ razvojem informacijskih tehnologij in mobilnih naprav teorija starševske mediacije ne pokriva kompleksnosti in dinamike, $s$ katero digitalni mediji vstopajo v družinske prakse, in njihovih tako negativnih kot pozitivnih učinkov (Clark, 2011; Livingstone, Ólafsson, Helsper, Lupiáñez-Villanueva, Veltri in Folkvord, 2017). Tradicionalne oblike starševske mediacije so v času mobilne tehnologije manj ustrezne in nemalokrat neučinkovite (Mascheroni in Ólafsson, 2014). Restriktivna mediacija s tehničnim nadzorom je še v uporabi, skupno gledanje in aktivna mediacija ne zadoščata več (Livingstone idr., 2017). Pri internetnih praksah so otroci pobudniki in pri usvajanju strategij vodijo pred starši, kar imenujejo avtorji vzvratna socializacija (Valcke, Bonte, Wener in Rots, 2010; Livingstone idr., 2017). Clark (2011) starševsko mediacijo obravnava v sovplivu z dejavniki, kot so slog starševstva in čustva, ki so pod pritiskom dinamike med tehnologijo, družin- 
skimi člani in njihovimi interesi ter potrebami. Na primer, otrokova uporaba digitalnih medijev pri starših vzbuja skrb, medtem ko pri otroku ali mladostniku veselje in zadovoljstvo (ibid).

Raziskave opozarjajo, da se raziskovalci bolj usmerjajo na nevarnosti in negativne učinke, premalo pa na priložnosti in na učinkovanje uporabe digitalnih medijev na učenje in razvoj ter na metode aktivne mediacije za spodbujanje učenja (Vaala in Bleakley, 2015; Troseth, Russo in Strouse, 2016; Livingstone idr., 2017). Raziskovalci opozarjajo na pomembno dejstvo, da uporaba digitalnih medijev v družinskem okolju v predšolskem obdobju spodbuja porajajočo se pismenost (Plowman, Stephen in McPake, 2008) in razvoj dispozicij za učenje (Plowman, McPake in Stephen, 2012).

Chakroff in Nathanson (2011) med pozitivnimi učinki navedeta razvoj otrokovega besednjaka in pripravljenost na šolo, vpliv prosocialnih TV-oddaj na otrokov prosocialni razvoj ter vpliv igranja računalniških iger na prostorske in koordinacijske spretnosti. Pregled raziskav v obdobju 2009-2014 o vplivu uporabe digitalnih tehnologij na učenje otrok med tretjim in šestim letom izpostavi pismenost, vključevanje, interakcijo, matematiko (Zomer in Kay, 2016).

Clark (2011) uvede participativno učenje kot alternativo aktivni mediaciji, pri njem pa starši skupaj z otrokom uporabljajo digitalne medije za učenje. Na predšolski stopnji lahko med aktivno mediacijo v obliki participativnega učenja uvrstimo tudi vodeno igro z digitalnimi tehnologijami. Digitalna tehnologija po ugotovitvah raziskave, ki so jo izvedli Plowman, McPake in Stephen $(2010$; 2012) med starši in vzgojitelji, prispeva k učenju in razvoju na tri poglavitne načine: (1) Razvija spretnosti za razumevanje funkcionalnosti in interaktivnosti digitalnih medijev kot tudi sposobnosti za otrokovo manipulacijo le-teh. (2) Širi znanja in razumevanje sveta na različnih kurikularnih področjih ob uporabi programov, spletnih strani in digitalne knjige. (3) Razvija dispozicije za učenje na afektivnem, socialnem in kognitivnem področju (Plowman, McPake in Stephen, 2012).

Starši in pedagoški delavci v vrtcu potrebujejo konkretne smernice o uporabi digitalne in izobraževalne tehnologije $v$ različnih razvojnih obdobjih, ki digitalne aktivnosti umestijo med preostale otrokove aktivnosti in pokrivajo vsa področja uče- 
nja, in ne le splošnih. Raziskovalci z različnih področij označujejo kot neustrezna polarizirana stališča in posplošeno gledanje na digitalno tehnologijo kot škodljivo ali označujejo njeno uporabo zgolj kot pozitivno. Pediatri opozarjajo na uravnotežena priporočila pediatričnih združenj, ki obravnavajo tako negativne kot pozitivne vidike in potenciale tehnologije za učenje in razvoj (Straker, Zabatiero, Danby, Thorpe in Edwards, 2018). Raziskovalci na področju medijskih študij in izobraževanja poudarjajo potrebo po celoviti in kontekstualizirani obravnavi, ki povezuje prakse družine in šole ob spoprijemanju z zahtevami družbe po kompetencah za 21. stoletje ( $\mathrm{Li}$ vingstone idr., 2017).

Livingstone in sodelavci (2017) so razvrstili starševsko mediacijo v dva sklopa: v mediacijo za omogočanje uporabe digitalne tehnologije in v restriktivno mediacijo, ki nadzira in omejuje. Mediacija za omogočanje uporabe digitalne tehnologije je sorodna aktivni starševski mediaciji, ki je bila uveljavljena v času televizije. Medtem ko je aktivna mediacija vključevala predvsem pogovor z otrokom, pa mediacija za omogočanje uporabe digitalne tehnologije podpira otrokovo aktivnost ob upoštevanju visoke kompleksnosti digitalnih medijev. Vključuje razvijanje otrokovih spretnosti, interveniranje in spodbujanje h kakovostni uporabi digitalnih medijev. Mediacija za omogočanje uporabe digitalne tehnologije zahteva od staršev razvite digitalne spretnosti in poznavanje varne uporabe interneta ter naklonjenost uporabi digitalnih tehnologij (Livingstone idr., 2017). Rezultati raziskav kažejo, da naklonjenost uporabi in izkušnje z uporabo vplivajo na izbiro mediacijskega sloga staršev (Valcke, Bonte, Wener in Rots, 2010; Livingstone idr., 2017).

\section{Digitalna tehnologija v otrokovem igralnem okolju}

Otrok se rodi v kulturno okolje, ki ga zaznamujejo kulturna orodja, njegova igra pa je primarni način kulturnega razvoja (Vigotski, 1978). S svojim okoljem je v interakciji, v kateri potekajo izmenjave s posredniki, med katere spada v sodobni družbi digitalna tehnologija. Otroška igra je v svojem bistvu avtotelna dejavnost, sestavlja velik del njegovega vsakdana in je pomembna za njegov razvoj. Avtotelna dejavnost je notranje motivirana, samovzdržna in otroka potegne v njen tok (Rautio, 2013). Otrok se igra iz svoje radovednosti in notranje potrebe po igri. Spretnosti igranja razvija s samo igro kot avtotelno dejavnostjo, v katero vključuje material, predmete 
iz svojega neposrednega okolja in druge oblike izmenjave in posredovanja v okolju. Igra otroku omogoča doživljanje socialnega kulturnega okolja, ki ga dojema in interpretira skozi igro (Vigotski, 1978). Otrokova igra je vir razvoja, omogoča mu odmik od konkretnih izkušenj in razvoj mišljenja, z vzpostavitvijo območja aktualnega razvoja, v katerem otrok ravna nad svojimi sposobnostmi (Vigotski, 1987).

$\mathrm{V}$ primerjavi s socialno-kulturnim pogledom na otroško igro kognitivna teorija igre izpostavlja razvojno ustrezne igralne aktivnosti, izhajajoč iz podmene, da je otrokova igra pogojena z otrokovim razvojem. Piaget (1962) opiše tri stopnje. Na prvi stopnji zaznavno gibalnega in zaznavno čutnega razvoja otrok razvija funkcijsko oz. praktično igro (raziskovanje in senzomotorične aktivnosti). Na drugi stopnji otrok razvija simbolno igro, ki mu omogoča reprezentacijo izkušenj v okolju. Posebna oblika igre, ki omogoča prehod od senzomotorične na simbolno, je konstrukcijska igra. Na tretji stopnji otrok razvija igro pravil.

Različni avtorji igro opredeljujejo razvojno. Hutt (1966) igro razvrsti v epistemično, v kateri otrok raziskuje svoje okolje in svoje zaznavne sposobnosti, in ludično, $v$ kateri z domišljijo raziskuje in si zamišlja, kako lahko sam uporabi različne premete iz okolja. Bird in Edwards (2015) interpretirata epistemično in ludično igro v socialno-kulturni perspektivi, uporabo orodij kombinirano v kontekstih epistemične in ludične aktivnosti.

Toličič (1961) v predšolskem obdobju razvršča igro na funkcijsko, domišljijsko, dojemalno in ustvarjalno igro. Dojemalna igra vključuje poslušanje pravljic, opazovanje, posnemanje, medtem ko ustvarjalna sestavljanje, pripovedovanje, risanje, ples, petje.

Simbolna igra otroku vzpostavlja razvojno območje, v katerem mu domišljija omogoča interpretacijo okolja in delovanje nad lastnimi sposobnostmi (Vigotski, 1978). Za simbolno igro je značilna interpretacija družbeno-kulturnega okolja z usmerjanjem vase (avtosimbolna igra), igro vlog in z odmikom od resnične situacije in njenim preseganjem (Vigotski, 1978, str. 99). Skupinska simbolna ali sociodramska igra je simbolno bolj zapletena. Ob interakciji in verbalni komunikaciji potekajo različne oblike simbolne igre, posnemanje, pretvarjanje, vezano na igrače, ali verbalno pretvarjanje (Marjanovič Umek in Kavčič, 2001). V sociodramski igri otrok po- 
doživlja dejanske ali domišljijske izkušnje v poteku lastnega osmišljanja in interpretacije (Lindon, 2001).

Otrok z igro razvija številne spretnosti, ki so sestavni del igre. Nasprotna je alotelna igra, ki je instrumentalizirana in pogojena z zunanjimi vzgibi in cilji. Med alotelno igro vključujemo didaktično igro, načrtovano glede na vzgojno-izobraževalne cilje.

Digitalna tehnologija vstopa $\mathrm{v}$ otroško igro $\mathrm{v}$ vseh razvojnih ravneh. Ob tradicionalnih igračah (plišaste igrače, punčke, sestavljenke ipd.) se otroci srečujejo z digitalnimi igračami. Digitalne igrače razvrstimo na zaslonske digitalne igrače in digitalne igrače brez zaslonov (Stephen in Plowman, 2014). Otroci generacije vmesnikov na dotik so izpostavljeni digitalnim medijem od rojstva (Plowman, McPake in Stephen, 2008) in nimajo izkušnje preddigitalne dobe. Otrok pri igri uporablja različne digitalne naprave. Med tistimi, ki ne spadajo med igrače, otrok pri igri uporablja pametni telefon, tablični računalnik, osebni ali prenosni računalnik, digitalno kamero, digitalni fotoaparat. Otrok ravna z videokamero in fotoaparatom, posluša glasbo, uporablja avdiosnemalnike in naprave za poslušanje.

Kritike digitalne igre, češ da omejuje ustvarjanje, avtorji zavrnejo (Bolstad, 2004; Stephen in Plowman, 2014). Otrok se pri ustvarjalni igri izraža ob uporabi različnih naprav, in ne le z uporabo izbranih računalniških iger.

Med digitalne igrače brez zaslonov štejemo pametne igrače ( $\mathrm{z}$ vgrajenimi senzorji za prepoznavanje otrokove interakcije in odzivanje različnih delov igrače) in povezane igrače (povezane s pametnim telefonom, računalnikom idr., med njimi tudi povezane igrače, ki zbirajo in posredujejo informacije o otroku na internetu, kar jim omogoča reakcijo na otrokovo interakcijo). Novo področje otroške igre z nastankom digitalnih igrač, ki so povezane $\mathrm{z}$ internetom, predstavljajo igrače razširjene resničnosti in tehnologije kombinirane resničnosti (Yilmaz, 2016). Imenujemo ga internet igrač, igrače povezuje $z$ internetom in prek senzorjev omogoča programiranje igrače ter njeno komunikacijo $\mathrm{z}$ otrokom ali $\mathrm{z}$ drugimi igračami. Interaktivne igrače omogočajo: celostno izkušnjo, ki vključuje taktilno, domišljijsko, funkcionalno mehansko in čustveno izkušnjo; različne vrste povratnih informacij; nadzor otroka ali kombiniran nadzor s starši (Lampe in Hinske, 2007). 
Model kombiniranega domišlijskega sveta (Stapleton in Hughes, 2003) pri otrokovi igri združuje fizično in virtualno okolje (Slika 5) ter spodbuja različne oblike domišljijske igre. Otrokov igralni prostor v igralnici nadgrajuje virtualna resničnost, vzpostavljena je razširjena resničnost za otrokovo individualno ali sociodramsko igro, ki poteka s pripovedovanjem zgodb. Tradicionalne igrače so opremljene z elektronskimi in virtualnimi sestavinami, dodano imajo multimedijsko vsebino (Lampe in Hinske, 2007). Starši, ki otroku predstavljajo pametne in druge digitalne igrače, potrebujejo razvite digitalne kompetence, med njimi tudi kompetence za varno uporabo digitalnih igrač.

Slika 5: Model domišljijskega sveta otroka ob uporabi digitalnih igrač (Stapleton in Hughes, 2003)

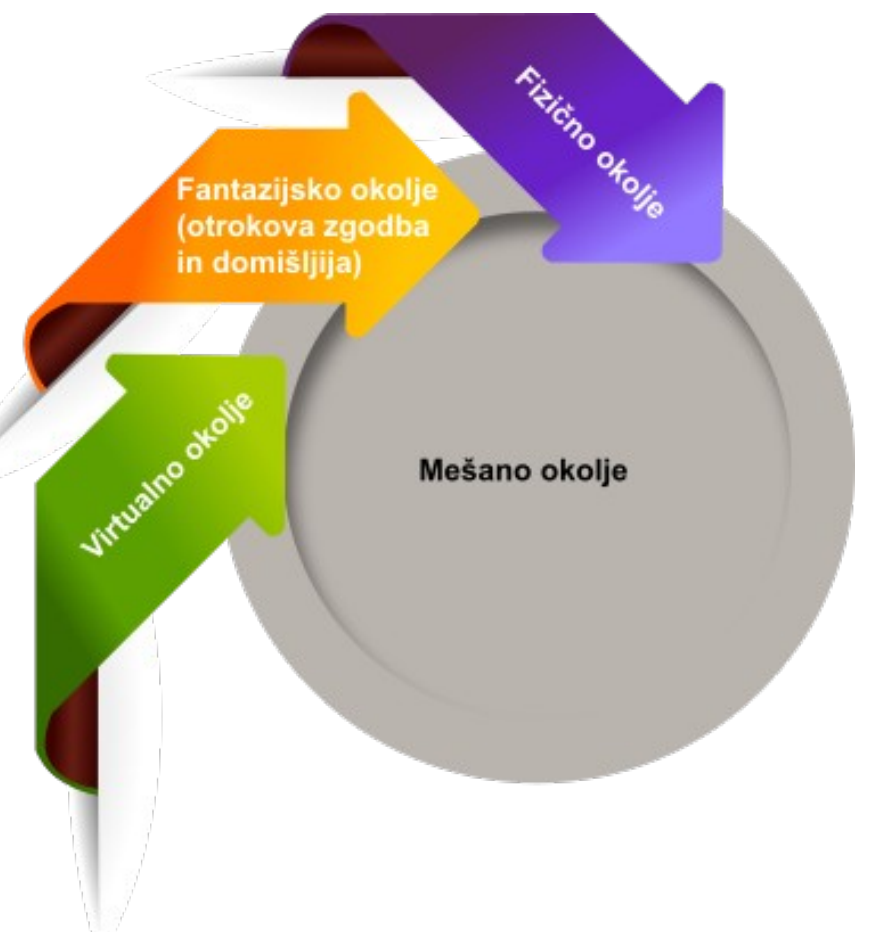

Digitalna igra je obravnavana v okviru treh pristopov: preučevanja, $\mathrm{v}$ kolikšni meri spadajo digitalne aktivnosti na področje otrokove igre; primerjave tradicionalnih in tehnoloških igrač in ugotavljanje morebitnega spodbujanja novih vrst igre $s$ tehnološkimi igračami; preučevanja kontekstov otrokove igre in razlage digitalne 
igre kot kulturno umeščene dejavnosti (Edwards, 2013). Meje med tradicionalno in digitalno igro se brišejo (Marsh, 2010). V predšolskem obdobju je digitalna igra kot kulturno umeščena dejavnost podlaga pri načrtovanju pedagoških pristopov (Edwards, 2013). Kulturno umeščene digitalne igrače in igre se preučujejo tudi z vidika prikritega kurikula (Edwards, 2015). Kurikul naj vključuje digitalno tehnologijo na več načinov.

- Otrok naj uporablja orodja in predmete v svojem okolju za različne vrste igre, epistemično (raziskovanje in reševanje problemov), funkcijsko ali praktično (senzomotorične sheme), ludično (simbolne, domišljijske, inovativne dejavnosti). Avtorji opozarjajo, da tehnološka igra zmanjšuje stopnjo kompleksnosti, značilno za posnemovalno in domišljijsko igro (Johnson in Christie, 2009; Smirnova, 2011; Edwards, 2015). Digitalna igrača z vgrajenimi mehanizmi in interaktivno programsko opremo je samozadostna, aktivnosti izvaja neodvisno od otroka in ga celo vodi. Otrokova ustvarjalnost je s tem zavrta, pri igranju z igračo, denimo punčko, otrok ne animira njenih čustev, vgrajeni interaktivni mehanizmi pa nadomeščajo otrokovo fantazijo (Smirnova, 2011). Raziskovalci opozarjajo na težave ločevanja smisla od objekta (Leong in Bodrova, 2012, Edwards, 2013; Bird in Edwards, 2015), kar je pomembno pri razvoju simbolnega mišljenja (Bird in Edwards, 2015).

- Z igro se otrok uči digitalnih spretnosti in spoznava značilnosti digitalnih tehnologij. Digitalne spretnosti začne razvijati zgodaj, saj digitalna tehnologija v otrokovo življenje vstopi že zelo zgodaj. Čeprav igra predstavlja temeljni način učenja v predšolskem obdobju, Bird in Edwards (ibid.) menita, da nimamo vpogledov $\mathrm{v}$ procese učenja digitalnih spretnosti otroka, ki potekajo z igro.

- Pri igri s tehnologijo se otrok uči na različnih področjih, zato je razvoj didaktičnih programov za predšolsko stopnjo vse intenzivnejši. Pri digitalnih igračah in programih, razvitih za domačo uporabo in za globalni trg, je potrebna obravnava tudi z vidika prikritega kurikula, ki zadeva kulturno tradicijo in prakse ter načine interakcije pri poučevanju in učenju, ki jih ne bi smeli nekritično vnašati v otrokovo kulturno okolje (Edwards, 2015). Pri uporabi didaktičnih programov otrok potrebuje razvite digitalne spretnosti. 


\section{Starševska mediacija pri uporabi digitalnih tehnologij}

Med dejavniki, ki vplivajo na zgodnji otrokov stik s tehnologijo, je vpliv staršev. Starši so otrokovi vzorniki in posredniki pri njegovi uporabi medijev (Plowman, McPake in Stephen, 2008). Od njihovega pojmovanja tehnologije in njene vloge v otrokovi igri je odvisen tudi pristop pri uporabi. Raziskava (Plowman, McPake in Stephen, 2012) med starši predšolskih otrok o pojmovanjih staršev glede koristi uporabe računalnika v predšolskem obdobju je identificirala štiri področja, ki zajemajo:

- razvoj spretnosti ravnanja z računalnikom,

- širjenje razumevanje sveta,

- razvoj dispozicij za učenje (samostojnost pri ravnanju z računalnikom, ki jo otrok lahko prenese na druga področja),

- razumevanje vloge tehnologije $v$ vsakdanjem življenju iz opazovanja odraslih in ko se sami otroci vključujejo v naprednejšo uporabo,

- spodbuden vpliv načrtnega delovanja v predšolskih vzgojno-izobraževalnih zavodih na družinske prakse.

Vloga staršev pri vzpostavljanju varnega in spodbudnega okolja vključuje mediacijo pri uporabi medijev in medijsko pismenost (Chakroff in Nathanson, 2011). Tako pri mediaciji kot pri medijski pismenosti je ključna kritična obravnava medijev in njihovih učinkov. Medijska pismenost je večdimenzionalna in vključuje spoznanja medijskih študij, sociologije, psihologije, pedagogike in zdravstva. Pri ozaveščanju staršev imajo pomembno vlogo vzgojitelji in učitelji, ki te vsebine obravnavajo že v predšolskem izobraževanju.

Evropska raziskava opisuje medijsko socializacijo (Süss, Lampert in Wijnen, 2009, v Chaudron, 2015), ki izhaja iz osnovnega načela, da otroci ne smejo biti izključeni iz uporabe medijev, temveč jih morajo smiselno in varno uporabljati na različnih področjih. Med pedagoškimi pristopi naštejejo: učenje kakovostne uporabe z igro vlog, ki izhaja iz otrokovih izkušenj in čustev; starševski nadzor vsebin; vpeljavo novih medijskih tehnologij v skupni obravnavi z otrokom, pri čemer ga je treba opozarjati na nevarnosti; otrokovo pisanje dnevnika o medijih, novostih in lastnih izku- 
šnjah; otrokovo samostojno izražanje, v smislu, da izkušnja ni posredovana s strani staršev (Süss, Lampert in Wijnen, 2009, v Chaudron, 2015, str. 57-58).

Tehnološke igrače vse bolj vstopajo v igro. Preproste električne in elektronske igrače oz. igrače z napajanjem, ki so tradicionalno imele mesto v otrokovem okolju, zdaj nadomeščajo digitalne igrače in digitalne naprave. Otrokovo igralno okolje vse bolj vključuje digitalna sredstva. Osebni računalnik na mizi, s spremljajočimi ergonomskimi zahtevami, in mobilne naprave, ki omogočajo gibanje po prostoru.

Zaradi povečanega deleža aktivnosti z zaslonom je osiromašena interakcija otroka $z$ odraslimi in otrokova igra, ki je ključna za njegovo učenje in razvoj. Kot prikazuje slika 6, je pri dnevnih aktivnostih pomembna: (1) mediacija staršev za omogočanje uporabe digitalne tehnologije s participativnim učenjem in vodeno igro z digitalnimi napravami. Pri interakciji ob napravi, tabličnem računalniku ali telefonu je pomembna verbalna in neverbalna komunikacija z očesnim stikom, telesnimi kretnjami, kimanjem glave, gibanjem po prostoru. Otrokova dejavnost naj bo (2) aktivna, in ne pasivna. Otrok je pri digitalnih aktivnostih gibalno aktiven, aktivira finomotoriko in telesne gibe. Tako se pri uporabi tabličnega računalnika ali mobilnega telefona prosto giblje po prostoru (Volk, Cotič, Zajc in Istenič Starčič, 2018). Priporočena je interakcija $\mathrm{z}$ zaslonom na dotik in $\mathrm{z}$ manipulacijo $\mathrm{z}$ digitalnimi in s fizičnimi objekti (AAP, 2016). Aktivnosti potekajo tudi na kognitivni ravni, ko se otrok vključuje v aktivnosti, ki potekajo na digitalni napravi. Socialno-čustveno je otrok dejaven, ko je $v$ interakciji z drugimi osebami, ki so prisotne ob njem. Raziskovalci poročajo, da se starši zavedajo pomembnosti povezovanja digitalnih aktivnosti s tradicionalnimi aktivnostmi, pri katerih gre za vključevanje digitalnih v druge tradicionalne aktivnosti otroka (Stephen in Plowman, 2014). 


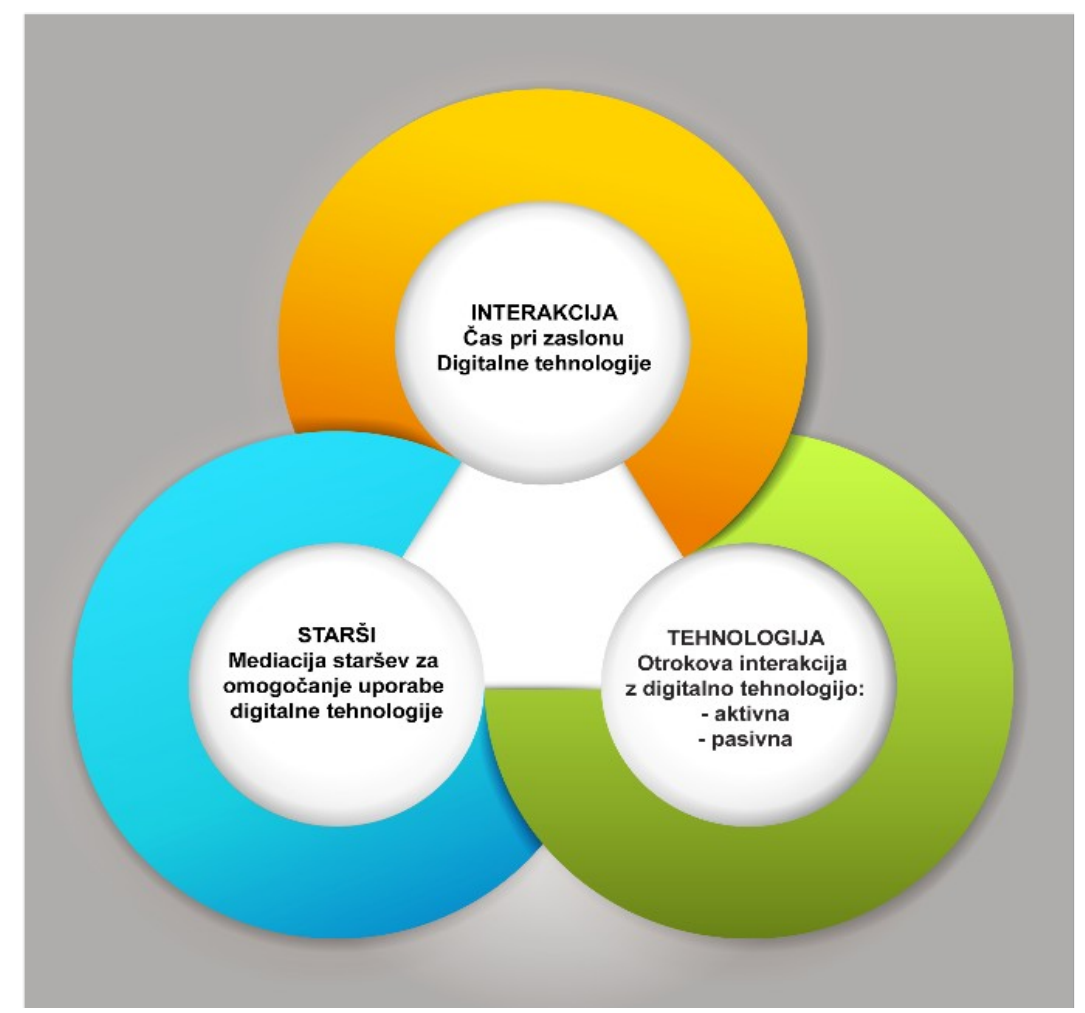

\section{Partnerstvo vzgojitelja s starši}

V predšolskem obdobju se otrok razvija skozi izkušnje v različnih okoljih, primarni okolji sta družina in vrtec. Bronfenbrenner (1979) pri tem izpostavlja prepletenost različnih okolij in interakcij med njimi. Razvoj porajajoče se pismenosti se začne v vsakdanji interakciji v družinskem okolju, pri čemer so pomembni različni viri in med njimi vse bolj digitalna tehnologija (Marsh idr., 2017). Pri uporabi digitalnih medijev otrok namreč ne razvija zgolj digitalnih spretnosti, temveč pri tem razvija dispozicije za učenje in se uči na vseh področjih (Plowman idr., 2010; 2012).

Raziskave poročajo, da je otrokovo primarno okolje vir izkušenj z digitalnimi mediji, ki ga vzgojitelj vključuje pri vsakdanjem delu v vrtcu. Pri tem upošteva izkušnje različnih okolij, iz katerih prihajajo otroci, in vzpostavlja širši kontekst družbe- 
no-kulturnih praks. Izsledki raziskave v evropskih državah kažejo, da nekateri starši dobro poznajo in otroku omogočajo kakovostne digitalne aplikacije, drugi starši pa jih ne poznajo in nimajo idej za njihovo uporabo (Chaudron, 2015). V raziskavi poudarjajo vzgojiteljevo vlogo ozaveščanja in usposabljanja staršev o digitalni tehnologiji in spodbujanju otroka k njeni kakovostni uporabi (ibid.).

Pri obravnavi digitalne tehnologije v zgodnjem obdobju v partnerstvu s starši vzgojitelj sledi štirim ključnim vidikom vloge digitalnih tehnologij:

- otrokov razvoj poteka $\mathrm{z}$ igralnimi aktivnostmi, $\mathrm{v}$ katerih je otrok $\mathrm{v}$ interakciji z okoljem in s kulturnimi artefakti, med katerimi so vse bolj razširjeni digitalni,

- digitalne tehnologije omogočajo razvoj digitalnih spretnosti otroka,

- digitalne tehnologije omogočajo razvoj dispozicij za učenje in

- digitalne tehnologije in digitalne spretnosti omogočajo učenje na različnih kurikularnih področjih.

Obravnava kontekstov, $\mathrm{v}$ katerih se digitalna tehnologija uporablja $\mathrm{v}$ zgodnjem obdobju, terja etnografske študije v avtentičnih okoljih in vključevanje staršev kot aktivnih deležnikov, ki spremljajo otrokove aktivnosti (Marsh idr., 2015). Empiričnih raziskav, ki bi poglobljeno preučevale uporabo digitalnih tehnologij v otrokovem zgodnjem obdobju, ni veliko. Raziskava kvalitativnega spremljanja okolja družine od rojstva do osmega leta je vključila opazovanje in intervjuje s starši (Chaudron, 2015).

Partnerstvo vzgojitelja in staršev vključuje sodelovanje staršev v zavodu in neposredno ali posredno sodelovanje $\mathrm{v}$ vzgojno-izobraževalnem delu $\mathrm{z}$ otroki $\mathrm{v}$ vrtcu in doma. M. Batistič Zorec in T. Turnšek (2002) vključujeta področje sodelovanja med vrtcem in družino $v$ posredno raven spremljanja in zagotavljanja kakovosti predšolske vzgoje.

Tradicionalna delitev na formalne (govorilne ure) in neformalne oblike sodelovanja (komunikacija in aktivnosti po dogovoru staršev in vzgojiteljev) je s podporo sodobnih informacijsko-komunikacijskih tehnologij presežena. Vzgojno-izobraževalni zavodi uporabljajo različne sisteme in pristope pri vzpostavljanju partnerstva $s$ 
starši, med razširjenimi so dokumentacijsko-informacijski sistemi, ki nadgrajujejo prvotne funkcije, povezane s komunikacijo in z organizacijo dnevnih rutin. Orodja za komunikacijo in sodelovanje na daljavo namreč omogočajo različne oblike sinhrone in asinhrone komunikacij in s tem tesneje povezuje okolji vzgojno-izobraževalnega zavoda in družine. Le-to omogoča kakovostnejše partnerstvo pri aktivnostih na področju načrtovanja, izvedbe in evalvacije kurikula. Zagotovljena je večja transparentnost izvedbenega kurikula z dnevnimi, tedenskimi in letnimi pripravami vzgojiteljevega dela in digitalnimi učnimi viri. Vzgojitelji pri načrtovanju in oblikovanju učnih virov sodelujejo s kolegi v matičnem in drugih vzgojno-izobraževalnih zavodih in s starši. Priprave in učni viri se lahko uporabljajo v povezovanju okolij vrtca in družine.

Partnerstvo med vzgojiteljem in starši spodbudno vpliva na počutje, medsebojno zaupanje in varnost; omogoča povezovanje in kontinuiranost med obema okoljema (Sheridan, Knoche, Edwards, Bovaird in Kupzyk, 2010) in s tem višjo kakovost uporabe digitalnih tehnologij $v$ vrtcu in domačem okolju. Zgodnje učenje zaznamujeta dva pomembna prehoda od doma v vrtec in kmalu zatem iz vrtca v šolo. Berčnik in Devjak (2017) med ključnimi vlogami partnerstva navajata pripravljenost na šolo s skrbjo za otroke, ki so slabše prilagojeni za prehod iz vrtca v osnovno šolo, in vpliv na akademsko uspešnost.

Partnerstvo temelji na motivaciji za sodelovanje vseh vključenih (Resman, 1992). Raziskave kažejo različnost pojmovanj otrokovih potreb in praks pri uporabi digitalne tehnologije med družinami znotraj enakih kulturnih okolij in med kulturnimi okolji. Nekateri starši menijo, da digitalna tehnologija omogoča otrokov razvoj in prinaša potencial za njegovo akademsko uspešnost, medtem ko drugi vidijo predvsem tveganja, ki jih prinaša uporaba tehnologije v zgodnjem otroštvu (Rideout, 2011).

Vzajemno sodelovanje pri obravnavi digitalnih medijev omogoča obojestranski vpogled; starši poznajo prakse v krogu družine, vzgojitelju je v partnerstvu omogočen vpogled v raznolikost družinskih praks otrok, ki so podlaga organizacije dela v vrtcu. Pristopi k partnerstvu temeljijo na vzgojiteljevi senzibilnosti za potrebe otrok in staršev ter na prepoznavanju starševskega sloga, kar poteka tudi na manj transpa- 
rentne in oprijemljive načine, in ne le $\mathrm{v}$ obliki dogodkov, kot so denimo roditeljski sestanki in delavnice (Jeynes, 2011). Partnerstvo temelji na zaupanju, vzpostavljeno je vzajemno, za čas trajanja programa vrtca, in se odraža v vsakodnevnih aktivnostih. Vzgojitelj in starši izmenjujejo izkušnje otrokovega igralnega okolja družine in vrtca ter jih povezujejo v celovito izkušnjo. Vzgojitelj pridobi v partnerstvu informacije o otrokovih vsakodnevnih izkušnjah v domačem okolju, igralnih navadah in interesih, dnevnih rutinah hranjenja, gibanja in otrokovem aktualnem razvoju. Digitalna tehnologija pomembno posega med dnevne aktivnosti in rutine na različnih področjih. Pediatrična združenja in raziskovalci zato spremljajo uporabo digitalnih tehnologij med ključnimi dejavniki otrokovega okolja (dnevne aktivnosti, prehranjevanje, gibanje, uporaba digitalnih tehnologij), njihovih potencialov in učinkov na razvoj in učenje (Bellows, McCloskey, Clark, Thompson, Bekelman, Chamberlin in Johnson, 2018).

Pri vzpostavitvi partnerskega odnosa poteka dogovarjanje o načinih komunikacije in sodelovanja na področju digitalne tehnologije, njihove uporabe doma in pri pedagoških pristopih v vrtcu. Partnersko sodelovanje vključuje skupne aktivnosti, med katere spadajo razprave in izmenjava izkušenj, dejavnosti starševske mediacije in opazovanja otroka pri delu z digitalno tehnologijo v domačem okolju. Ob upoštevanju dejstva, da sta okolje doma in vrtca v interakciji ter vključujeta vse partnerje z njihovimi različnimi družbeno-kulturnimi izkušnjami, imajo pomemben vpliv na otrokovo uporabo tehnologije $\mathrm{v}$ družinskem okolju tudi profesionalne izkušnje staršev (Bronfenbrenner, 1979), ki posredno sooblikujejo tudi digitalne prakse v vrtcu.

Partnerstvo med vzgojiteljem in starši ne pomeni, da vzgojitelj staršem nudi navodila za domače aktivnosti, temveč vzajemno sodelovanje pri načrtovanju in refleksiji dela z otrokom tako doma kot v vrtcu (Karila in Alasuutari, 2012). Na področju digitalnih tehnologij partnerstvo poteka na več področjih vključevanja digitalne tehnologije v kurikul, ki se v vrtcu uresničuje v kontinuiteti z domačim okoljem:

- upoštevanje otrokovih igralnih navad in interesov pri vključevanju digitalne tehnologije v otrokovo spontano igro;

- starševska mediacija pri uporabi digitalne tehnologije za spoznavanje tehnologije in razvijanje digitalne pismenosti (Livingstone idr., 2017); 
- razumevanje otroka, njegovih spretnosti in potencialnega razvoja digitalnih spretnosti, ki posredno prispeva k uporabi digitalne tehnologije za razvoj dispozicij za učenje in pri učenju na različnih področjih kurikula;

- spoznavanje in kritično vrednotenje različnih aplikacij, didaktičnih programov, njihove pedagoško didaktične vrednosti in ustreznosti za različna razvojna obdobja po področjih kurikula;

- partnerstvo pri izvedbenem kurikulu vrtca.

Vzpostavitev partnerstva je dolgotrajen proces. Poteka po stopnjah, ki omogočajo pripravo partnerstva, analizo potreb in ciljev, oblikovanje skupne vizije in načrta, načrtovanje in evalviranje partnerskih procesov (Bryan in Henry, 2012). Vzpostavitev partnerstva vodijo načela demokratičnosti, pravičnosti in opolnomočenja (ibid.). Slovenski kurikul za vrtce načelo sodelovanja s starši šteje med temelje uresničevanja kurikula za vrtce.

Vzgojitelj vzpostavi partnerstvo s starši in jih poveže v delovno skupino za analizo stanja in za načrtovanje vključevanja IKT v dejavnosti vrtca. Lahko pripravi instrumente spremljanja, pri čemer je pomembno, da rezultate obdela skupaj s starši. Uporabi lahko anketiranje ali intervjuvanje staršev ali pa jim oblikuje protokol opazovanja za spremljanje in beleženje aktivnosti $\mathrm{v}$ določenem časovnem obdobju. Zvočne, video ali fotoanalize so občutljive za deljenje in obravnavo različnih deležnikov, vendar staršem omogočajo kakovostnejše opazovanje in beleženje ob pomoči avdiodokumentacije, videoogleda ali dokumentacije otrokovih dnevnih dejavnosti s fotografiranjem.

Pri vodenju skupine in organizaciji dela uporabi tehnologije za sodelovanje. Kakovostna že vpeljana orodja za sodelovanje vrtca s starši so vpeljana v dokumentacijsko-informacijskih sistemih (Istenič Starčič in Vukan, 2019). Računalniško podprta komunikacija omogoča kakovostno in učinkovito sodelovanje, saj poteka integrirano v avtentičnem družinskem okolju. Tehnologije omogočajo simulacijo, izmenjavo primerov dobre prakse in pogovor o tveganjih, povezanih s čezmerno uporabo ali neustreznimi oblikami uporabe digitalne tehnologije. Staršem predstavi metode starševske mediacije za uporabo digitalne tehnologije in razlike med njimi, mediacijo za omogočanje uporabe digitalne tehnologije in restriktivno mediacijo (Livingstone 
idr., 2017). Spodbuja načine skupne uporabe tehnologij z otroki in izgradnjo skupnega razumevanja vloge tehnologije v vsakdanjem življenju. Ozavesti starše, da bodo s sodelovanjem pridobili pomembne informacije za razvoj lastnega razumevanja otrokovih praks in ohranjali svoj tesni stik in komunikacijo o tehnologiji z otrokom v prihodnjih otrokovih razvojnih obdobjih.

Opazovanje se izvaja v opredeljenem časovnem obdobju, denimo v tednu dni. Opazovalni protokol je v evropski raziskavi v sedmih državah zajemal opis okolja (prisotnost naprav, igrač, dostop do narave, igrišč, knjižnice, telovadnice, kina idr.), opazovanje digitalnih aktivnosti, opazovanje digitalnih naprav pri otrokovi uporabi, opazovanje spretnosti otroka $\mathrm{z}$ napravami, opazovanje ravnanja staršev in otroka $\mathrm{z}$ digitalnimi napravami in starševske mediacije (Chaudron, 2015).

\section{Priporočila in tveganja}

Nacionalna organizacija za izobraževanje mlajših v ZDA je že leta 1996 poudarila, da ima tehnologija pomembno vlogo na vseh področjih življenja in da se bo njen pomen v prihodnosti povečeval (NAEYC - National Association for the Education of Young Children, 1996, v Rosen in Jaruszewicz, 2009). Priporočila Nacionalne organizacije za izobraževanje mlajših v ZDA (2012) za starostno obdobje od rojstva do osmega leta izhaja iz podmene, da je tehnologija otrokom potencialno škodljiva, zato jo je zanje treba izbirati in jih varovati pred njenimi škodljivimi učinki. Poudarjene so tudi prednosti tehnologije za učenje, za kar je potrebna podpora načrtnih intervencij, vključevanje pa naj poteka kombinirano s tradicionalnimi aktivnostmi, ki naj jih digitalne ne nadomeščajo (NAEYC, 1996). Priporočila ameriške akademije pediatrov $(2010 ; 2011)$ za otroke pred drugim letom starosti odsvetujejo gledanje zaslonov, za otroke po drugem letu starosti pa nadzorovano gledanje ob prisotnosti staršev, do največ dveh ur dnevno. Strokovnjaki opozarjajo, da otroci razvijajo pozornost do televizije že takoj po rojstvu, kar pripisujejo otrokovi izpostavljenosti prižgani televiziji v ozadju, tudi med otrokovo igro ali interakcijo z odraslim (Anderson in Pempek, 2005).

Priporočila pristojnih pediatričnih združenj, denimo Ameriške akademije pediatrov (AAP, 2016) in Kanadskega pediatričnega združenja (Canadian Pediatrics So- 
ciety, 2017), se počasi spreminjajo. Polarizirane obravnave prehajajo na bolj uravnoteženo obravnavo negativnih in pozitivnih vidikov ter potencialov tehnologije za učenje in razvoj (Straker idr., 2018). Posodobljena priporočila iz leta 2016 spodbujajo vključevanje vmesnikov na dotik pri učenju malčkov, ki naj bi omogočali igranju s tradicionalnimi igračami podobne interaktivne aktivnosti. Ameriška akademija pediatrov priporoča vključevanje aktivnosti $z$ vmesniki na dotik $\mathrm{v}$ starosti od 18 . meseca. Za starostno obdobje starosti med drugim in četrtim letom pa priporočajo uporabo kakovostnih didaktičnih programov. Pri uporabi priporočajo interakcijo staršev z malčkom (AAP, 2016). Kanadsko pediatrično združenje na prvem mestu izpostavi prednosti za učenje in razvoj, za tem tveganja (Canadian Pediatrics Society, 2017).

Avstralska priporočila zdravstvene organizacije odsvetujejo gledanje zaslonov in uporabo digitalne tehnologije pred drugim letom starosti. Priporočila zadevajo tudi interakcijo staršev z otrokom in omejeno vključevanje digitalnih medijev (Australian government department of health, 2012). Avstralska komisija za kakovost izobraževanja in nege otrok (Australian children's education and care quality authority) v okviru kurikula za predšolsko obdobje (Council of Australian governments, 2009) vključi digitalno tehnologijo $v$ učni cilj, »V komunikaciji uspešen otrok «: Otrok dela $\mathrm{z}$ različnimi besedili in razvija smisel ( $\mathrm{v}$ povezavi s tem so omenjena multimedijska besedila), Otrok predstavlja ideje in vzpostavlja smisel z uporabo različnih medijev ter Otrok uporablja IKT pri dostopanju do informacij, raziskovanju idej in predstavljanju svojega razmišljanja (Council of Australian governments, 2009). Podajajo priporočila za digitalno igro in uporabo tehnologije za razvoj otrokovih spretnosti za učenje in socialno interakcijo (Straker idr., 2018).

Ob prezgodnji in pretirani uporabi lahko prednosti na področju igre in učenja postanejo tveganja. Otrokovo neposredno okolje tvori interakcija z odraslimi in vrstniki. V najzgodnejšem obdobju je za otrokov razvoj potreben dotik (Serra, Miguel, Moura, Sampaio in Pereira, 2020). Interakcija staršev z otrokom temelji na neverbalni komunikaciji, gibanju, očesnem stiku, obrazni mimiki in dotiku, ki vzpostavlja varno okolje in spodbuja socialno-afektivni, kognitivni in psihomotorični razvoj otroka. Raziskave opozarjajo na vlogo dotika ob neverbalni komunikaciji z očesnim stikom in obrazno mimiko pri igri matere z otrokom (ibid.). 
Vnašanje posrednika $\mathrm{v}$ obliki tabličnega računalnika ali pametnega telefona $\mathrm{v}$ interakcijo in igro lahko siromaši in omejuje verbalno in neverbalno komunikacijo, če otrok in odrasel zreta v zaslon. Igra s tablico naj vključuje vse oblike neverbalne komunikacije, kot pri igri z igračami in drugimi predmeti. Starši vodijo in izzivajo otroka v igri ali pa ga spremljajo v njegovi spontani igri, pri čemer sta ključna dotik in neverbalna komunikacija. Uporaba računalnika za nadomeščanje igre, gibalnih aktivnosti in interakcije otroka s starši, vzgojitelji ali vrstniki je tvegana za otrokov razvoj in zdravje. Preučevanje digitalne tehnologije $\mathrm{v}$ otrokovih in družinskih rutinah $\mathrm{v}$ predšolskem obdobju je vključeno $\mathrm{v}$ intervencije za spodbujanje zdravih navad prehranjevanja in gibanja, ki so vpete $\mathrm{v}$ kulturni kontekst digitalnih praks družin (Bellows idr., 2018).

Vnos posrednikov, kot so tablični računalniki in pametni telefoni, spreminja način komunikacije in igre med otrokom in starši. Otrok v najzgodnejšem obdobju komunicira z gibom, z neverbalno komunikacijo. Pomemben je očesni stik med odraslim in otrokom, ki pa ga je z vključevanjem zaslonov manj, tudi kadar starši ob zaslonu komunicirajo z otrokom, saj so pogledi zazrti v zaslon. Digitalne igrače lahko dopolnjujejo tradicionalne igrače in spodbujajo otrokovo ustvarjalnost ali pa jo zavirajo (Johnson in Christie, 2009). Zaradi povečanega deleža aktivnosti z zaslonom je osiromašena otrokova igra, ki je ključna pri njegovem učenju in razvoju (Singer, 1981; Johnson in Christie, 2009; Smirnova, 2011). Posledica povečanja avdiovizualnih dražljajev v medijih je, da se zmanjša interes za fantazijsko igro. Digitalna tehnologija lahko vpliva na zmanjšanje spontane otroške igre ali jo okrni.

Raziskave kažejo povečanje gledanja zaslonov, kar vpliva na zmanjševanje interesa otrok za branje in na upad branja (Singer, 1981; Rideout, 2011). Izpostavljenost nasilju na zaslonih in igranje nasilnih računalniških iger vplivata na socialni razvoj in prosocialno ter antisocialno vedenje (Bandura, 1977; Singer, 1981). Povečana izpostavljenost nasilnim vsebinam zmanjšuje negativne čustvene odzive na nasilje in empatijo (Anderson, Gentile in Dill, 2012), slabša splošno počutje in povzroča motnje pozornosti ter spanja (Howard-Jones, 2011).

Pediatri navajajo potencialne nevarnosti na fizičnem, kognitivnem, čustvenem in socialnem področju. Na področju otrokovega fizičnega razvoja navajajo: osiroma- 
šeno in zavrto telesno držo, ponavljajoče se gibanje, nezgode in povečan delež sedentarnih aktivnosti na račun motorike, kar vodi v pešanje mišično-skeletnega in motoričnega razvoja. Na kognitivnem področju navajajo znižanje pozornosti, zmanjšane priložnosti za verbalno interakcijo, reševanje problemov in ustvarjalnost. $\mathrm{Na}$ čustvenem področju navajajo nastavke za odvisnost, depresijo, dostop do neustreznih vsebin in oglaševanja, na socialnem področju pa izolacijo, zmanjšanje interakcije iz oči v oči, nasilje in plenilsko pedofilijo (Straker idr., 2018).

Povečana uporaba tehnologije $\mathrm{v}$ družini zvišuje tveganja za problematično uporabo interneta $\mathrm{v}$ zgodnjem obdobju in nadaljnjih starostnih obdobjih. Evropska raziskava je povzela metodologijo petih kriterijev internetne odvisnosti (Grüsser in Thalemann, 2006, v Chaudron, 2015, str. 55):

- zoženje oblik obnašanja (neprestana misel na napravo, aplikacijo, igro),

- regulacija negativnega čustvenega stanja (uporaba naprave poteka kot oblika obvladovanja stresa in regulacija negativnih čustev s pozitivnim vzburjenjem in sproščanjem),

- dvigovanje tolerance (želen učinek regulacije negativnih čustev je lahko dosežen s povečevanjem pogostosti in časa uporabe),

- simptomi umanjkanja (zmanjševanje ali ukinjanje uporabe povzroča napetost, razdraženost, agresijo, zmanjševanje pozornosti na vse, razen na naprave, aplikacije),

- izguba nadzora (uporabnik ne nadzoruje uporabe in samoregulacije).

Kvantitativna študija v Belgiji je med psihosocialnimi težavami, ki se jih zavedajo starši, omenila naslednje vidike (Chaudron, 2015, str. 20-62):

- tehnologije pritegnejo in $s$ tem je povezana nenadzorovana čezmerna uporaba,

- gratifikacija, ki jo nudi uporaba digitalnih naprav in iger, vodi v odvisnost,

- občutki dolgočasja pri otroku, ki bi ga starši morali uravnavati s pestrostjo dejavnosti in razvijanjem otrokovih interesov,

- hiperstimulativne adrenalinske igre in spremembe razpoloženja,

- psihična razdražljivost in obremenjenost oči. 


\section{Izobraževalna tehnologija pri strukturiranju vzgojno- izobraževalnega okolja}

V Sloveniji kurikul za vrtec opredeli otroško igro kot ključno otrokovo dejavnost, ki predstavlja način otrokovega učenja in razvoja ter na naraven način združuje temeljna načela predšolske vzgoje in presega vpetost $\mathrm{v}$ akademski ali razvojni pristop (Bahovec idr., 1999, str. 10-11). Kurikul, temelječ na igri, je prevladujoč pri zgodnjem učenju. Igra je avtotelna dejavnost, otrok se igra zaradi igre same, pri njej pa doživlja svoje družbeno-kulturno okolje, ko v procesu interpretacije skozi domišljijo povezuje igro in resničnost (Vigotski, 1978). Pri igri otrok črpa iz družbenega in kulturnega okolja s temeljnim namenom igre kot avtotelne dejavnosti, ki je namenjena sama sebi in v kateri otrok razvija in izboljšuje svoje spretnosti igranja. Igra je v kontekstu kurikula vrtca opredeljena kot temeljna dejavnost, ki povezuje kurikularna področja (gibanja, jezika, umetnosti, družbe, narave, matematike) pri uresničevanju vzgojnoizo-braževalnih ciljev po načelih kakovostne vzgoje v vrtcu, ki otroku omogoča aktivnosti s predmeti in pridobivanje socialnih izkušenj (Bahovec idr., 1999, str. 10-11).

Razvoj predšolskega izobraževanja v funkciji priprave na šolo, ki bi omogočala poenoteno pripravo in izkušnje vsem otrokom v obdobju porajajoče se pismenosti, je bil deležen kritike zaradi svoje pretirane kurikularne naravnanosti in vzpostavljanja dihotomije učenja - igre, ker ne upošteva otrokovih naravnih in socialnih danosti (Weissberg, Hirsh-Pasek, Golinkoff in Kittredge in Klahr, 2016; Ilgaz, HassingerDas, Hirsh-Pasek in Michnick Golinkoff, 2018). Priprave na šolo, namenjene opravljanju kompenzacijske funkcije z didaktičnimi pristopi, ki so ozko ciljno usmerjeni na osnovno pismenost in razvoj spretnosti pripravljenosti na šolo, krnijo otrokovo spontano igro, ki je otrokova izvirna dejavnost razvijanja jezika, kognitivnih in socialno-kognitivnih sposobnosti (Ilgaz idr., 2018). Marjanovič Umek in Kroflič (2009) sta opozorila na kritična razvojna obdobja, v katerih vrtec vzpostavlja spodbudno okolje formalnega in neformalnega učenja $v$ povezanosti $z$ otrokovimi družinskimi izkušnjami in njihovimi različnimi kulturnimi praksami. Pri organizaciji dela v vrtcu so potrebni meddidsciplinarni pristopi, spodbujanje govornega razvoja, ki pomembno vpliva na vsa področja, razvoj metodik vseh kurikularnih področij, razu- 
mevanje prikritega kurikula pri rutinskih dejavnostih in upoštevanje različnosti otrok (Marjanovič Umek in Kroflič, 2009).

V vrtcu sta prisotni prosta in vodena igra. Vodena igra omogoča ravnotežje med upoštevanjem otrokovih naravnih sposobnosti in potreb po učenju skozi igro kot avtonomno in avtotelno dejavnostjo in odraslim vodenjem (Weissberg idr., 2016). Vzgojitelj z vodeno igro sovzpostavlja igralno okolje za otrokovo udejstvovanje ob upoštevanju otrokovih značilnosti in v poučevanju, usmerjenem na otroka, skrbi za vzpostavljanje učnega okolja na vseh kurikularnih področjih z ustvarjanjem otrokovega območja aktualnega razvoja (Vigotski, 1978). Raziskave so pokazale, da zgolj otrokova spontana igra ne prispeva $\mathrm{k}$ otrokovemu razvoju na jezikovnem in matematičnem področju, kot tudi, da različni pristopi tradicionalnega poučevanja niso tako učinkoviti, kot je vodena igra (Ilgaz idr., 2018). Posebna oblika je didaktična igra. Didaktične igrače so oblikovane za razvoj specifičnih učnih področij, so visoko strukturirane za določene načine uporabe in otrokovo igro ciljno usmerjajo in s tem omejujejo (Fekonja, 2001).

Otrokova osnovna dejavnost je igra, v kateri otrok razvija spretnosti igranja (Vigotski, 1978). Z njo se samostojno izraža zaradi igre same, in ne zaradi izdelkov, ki v igri nastanejo, oziroma zaradi spretnosti, ki jih v igri razvije. V igri otrok ustvarja, je ekspresiven zaradi svoje notranje potrebe, in ne zaradi reakcije na dražljaje iz okolja. $\mathrm{V}$ igri otrok ravna divergentno, dejavnost poteka $\mathrm{v}$ različnih smereh, ko raziskuje in manipulira $\mathrm{z}$ artefakti v svojem okolju (Ivić, 1981).

Pri organiziranem predšolskem izobraževanju so teoretiki opozorili na pomen ustreznega razmerja med prosto in vodeno igro in na neustreznost pretiranega nadomeščanja otrokove proste igre z didaktičnimi igrami (Weissberg idr., 2016; Ilgaz idr., 2018).

Izobraževalne tehnologije v kurikulu, temelječem na igri, se vključujejo na različne načine:

- Digitalna tehnologija in igrače so sestavni del kulturnega orodja, s katerim se otrok v spontani igri seznanja. 
- Vodena igra ima v pripravi na šolo funkcijo omogočanja ustreznega razvoja vsem otrokom na vseh kurikularnih področjih. $\mathrm{Na}$ otrokov razvoj pa vpliva splet dejavnikov $\mathrm{v}$ okolju, različna igralna sredstva in socialna interakcija. Vključevanje digitalne tehnologije poteka v vrtcu v vodeni igri za razvoj jezikovne in matematične pismenosti, umetnostno izražanje, gibalni razvoj, spoznavanje narave in družbe.

- Vključevanje digitalne tehnologije na tak način, da igra poteka ob povezovanju kognitivnega, psihomotoričnega in socialno-afektivnega področja učenja.

Digitalna tehnologija je del družbeno-kulturnega okolja, orodij in praks, ki so sestavni del otrokove igre. Čeprav je sodobna tehnologija spremenila tudi najpreprostejše operacije posameznikovega vsakdana na vseh področjih družbenega življenja, uporaba tehnologije ni integrirana po kurikularnih področjih (Yelland, 2005). Kritiki opozarjajo na prevladovanje pristopov, ki digitalno tehnologijo obravnavajo omejeno na razvoj digitalnih spretnosti, pri čemer spregledajo kompleksno vlogo digitalne tehnologije in njene vloge v družbi, družini in otrokovem življenju (Wohlwend, 2010, v Edwards, 2015). Med te pristope spada tudi vključevanje zgolj didaktične digitalne igre brez vključevanja digitalne igre $\mathrm{v}$ prosto oz. spontano in vodeno igro. Primer avstralskega kurikula za predšolsko obdobje vključuje digitalno tehnologijo $v$ učne cilje, »Otrok uspešen v komunikaciji«: Otrok dela z različnimi besedili in razvija smisel (v povezavi s tem so omenjena multimedijska besedila), Otrok predstavlja ideje in vzpostavlja smisel ob uporabi različnih medijev ter Otrok uporablja IKT pri dostopanju do informacij, raziskovanju idej in predstavljanju svojega razmišljanja (Council of Australian governments, 2009).

Slovenski kurikul za vrtce med primeri avdiovizualnih medijskih dejavnosti za starostno obdobje od tretjega do šestega leta odpira prostor dejavnostim na vseh treh področjih, ki so jih opredelili Plowman, McPake in Stephen (2012). Gre za:

- Dejavnosti za razvoj razumevanja funkcionalnosti in interaktivnosti digitalnih medijev kot tudi sposobnosti za otrokovo manipulacijo le-teh:

- snemanje s fotoaparatom, videokamero, diktafonom, fotografiranje, 
- gledanje filmov v kinu, na televiziji ali filmov, ki jih posname otrok sam ali starši, vzgojitelji,

- spoznavanje različnih televizijskih programov.

- Širitev znanja in razumevanja sveta na različnih kurikularnih področjih z otrokovo uporabo programov, spletnih strani in digitalnih knjig, ko:

- uporablja multimedijske igre in vzgojno-izobraževalne programe,

- bere in si izmišljuje zgodbo,

- reže in sestavlja nove prizore, tvori nove vsebine in likovne kompozicije, jih dopolnjuje z risbo in tiskanimi slikami ter detajli, izdela scenarij v obliki stripa.

- Razvoj dispozicij za učenje na afektivnem, socialnem in kognitivnem področju, ko:

- si zamišlja in ustvarja plesne vložke za dramske predstave in video,

- posluša, posnema in upodablja zvoke iz narave in okolja,

- zamišlja si, izbira in oblikuje lutke, prvine kostuma in scene za plesne, dramske in avdiovizualne dejavnosti.

\section{Didaktična načela}

Obravnavo vključevanja izobraževalne tehnologije v vzgojno-izobraževalno delo v vrtcu zaokrožamo z didaktičnimi načeli (Šilih, 1970; Blažič idr., 2003; Strmčnik, 2004; Ivanuš Grmek in Javornik Krečič, 2011; Kramar, 2009), ki integrirajo načela kurikula za vrtce (Bahovec idr., 1999, str. 10-11).

Prvo načelo Učna aktivnost v funkciji otrokovega razvoja zadeva vključevanje izobraževalne tehnologije skladno z otrokovimi zmožnostmi. Vključevanje tehnologije same po sebi ni smiselno, če ni načrtovano in vpeto v strukturo vzgojno-izobraževalnega procesa. Strmčnik obravnava učno aktivnost glede na vrsto (gibalna, čustvena, intelektualna), obliko (reproduktivna, produktivna, ustvarjalna), vodenje (zunanje, samovodeno) ter povezavo nižjih in višjih oblik aktivnosti (Strmčnik, 2001). Pri vzgojno-izobraževalni dejavnosti je ključno upoštevati otrokove aktivnosti, njegove pobude ter mu zagotoviti možnost aktivnega sodelovanja. 
V predšolskem obdobju je učna aktivnost prosta ali vodena igra. Vzgojitelju vodenje in spremljanje dejavnosti omogoča sprotno prilagajanje, vključevanje novih dejavnosti v ustreznem času in prepoznavanje kritičnih obdobij za učenje. Digitalna igra pokriva vse vrste igre in ni namenjena zgolj učenju digitalnih spretnosti (Edwards, 2013). Igra omogoča otrokovo avtentično/izvirno ustvarjalno aktivnost, ki je pogoj otrokovega razvoja in je prilagojena njegovim nagnjenjem (ustvarjanje, razmišljanje, reševanje, oblikovanje). Digitalna tehnologija sestavlja kulturno okolje, s katerim je otrok v interakciji in ga vključuje v igro. Digitalna igra je lahko integrirana v tradicionalne aktivnosti ali pa deluje kot samostojna aktivnost in $s$ tem osmišlja otrokov funkcionalni, senzorični in domišljijski svet. V okviru kurikularnih področij otroku omogočimo uporabo digitalnih tehnologij za funkcijsko, ludično, epistemično in druge oblike igre. Zagotoviti je treba povezovanje področij učenja (kognitivnega, socialno-afektivnega, psihomotoričnega), kajti otrok se uči ob uporabi vseh senzoričnih sistemov, dojemanje, fizična manipulacija, gibanje, vokaliziranje in verbalno izražanje). Kurikul za vrtce (1999) narekuje, naj organizirane dejavnosti spoštujejo otrokovo intimo in zagotavljajo varno, zdravju neškodljivo udejstvovanje.

Drugo načelo Enotnost učnokonkretnega in abstraktnega je v predšolskem obdobju zanimivo $\mathrm{z}$ vidika obravnave digitalne igre in njenih potencialov pri prehodu med različnimi reprezentacijami. Digitalno igro nekateri raziskovalci kritično vrednotijo, češ da zmanjšuje stopnjo kompleksnosti, značilno za posnemovalno in domišljijsko igro (Smirnova, 2011; Edwards, 2015) in da otežuje prehod med konkretnim in abstraktnim dojemanjem, potrebnim za razvoj abstraktnega mišljenja $\mathrm{v}$ osnovnošolskem obdobju (Leong in Bodrova, 2012; Bird in Edwards, 2015; Edwards, 2013).

Tretje načelo Strukturiranost in sistematičnost zadeva s kurikulom usklajeno načrtovanje in vključevanje digitalnih tehnologij, povezovanje kurikularnih področij in vrsto igre. $\mathrm{V}$ tem okviru je pomembno upoštevanje postopnosti in spodbujanja otrokovega odkrivanja in raziskovanja ter razvijanje spoznavnih in doživljajskih sposobnosti. Med izvedbo je potrebno preverjanje otrokovega razumevanja in spretnosti. Vzgojitelj aktivnosti v vrtcu povezuje z izkušnjami, ki jih ima otrok z digitalnimi aktivnostmi doma. 
Četrto načelo Problemskost v predšolskem obdobju je podlaga otrokovi epistemični igri že v najzgodnejšem obdobju. Otrokovo nagnjenje k samostojnemu reševanju problemskih situacij je ključno in zato naj si vzgojitelj prizadeva za nenehno postavljanje izzivov s problemskimi situacijami, ki otroku omogočajo eksperimentiranje in izkustveno učenje. Le-te spodbujajo otrokovo aktivnost, ki mora biti jedro pedagoškega delovanja. Otrok mora imeti možnost sodelovanja pri reševanju resničnih problemov v družini, z vrstniki in z vzgojiteljem.

Peto načelo Individualizacija zadeva vključevanje digitalne tehnologije ob poznavanju konkretnih značilnosti skupine in posameznikov. Individualizacija omogoča premoščanje razlik med otroki in organizacijo dejavnosti na način, da vsakemu otroku omogočimo njemu lastno izražanje in ustvarjanje. Zadeva tako spretnosti pri ravnanju s tehnologijo kot tudi sposobnosti na različnih kurikularnih področjih.

Šesto načelo Življenjskost je v dobi globalizacije in prevlade anglosaških modelov še predvsem pomembno. Digitalni mediji imajo ključno vlogo pri širjenju potrošništva in globalnih učinkov dominantnih kultur. Pri vključevanju digitalnih tehnologij ima vzgojitelj pomembno vlogo vključevanja spodbud iz otrokovega bližnjega okolja, ki otroku omogoča avtentične kulturne aktivnosti. Pomembna je obravnava življenjskih vprašanj, ki se otroku porajajo v njemu bližnjem in zanj avtentičnem okolju domišljije in resničnosti. Učno okolje mora omogočati raznolikost doživljanja, ki ga nudi takšno kompleksno in heterogeno okolje, ki se čim bolj približuje otrokovemu avtentičnemu okolju. Otrokov svet sestavljata resnično in domišljijsko okolje, ki morata biti vključena pri skupnem vzpostavljanju učnega okolja, v katerem ima otrok aktivno participativno vlogo. Internetni viri tujih ponudnikov, dekontekstualiziranih od otrokovega avtentičnega okolja, abstrahirajo otrokovo neposredno okolje. Za otrokov razvoj so ključnega pomena otrokove izvirne dejavnosti in vsebine, umeščene v otrokovo avtentično okolje.

Vzgojitelji skladno z Bronfenbrennerjevo (1979) ekološko sistemsko teorijo reflektirajo o prisotnosti in vlogi tehnologije $\mathrm{v}$ otrokovem življenju in o kompetencah in spretnostih, ki jih bo potreboval v svojem življenju (Rosen in Jaruszewicz, 2009). Pomembno je poznavanje otrokovih praks v družinskem okolju, ki se preučujejo v interakciji z družbeno-kulturnimi praksami. Raziskovanje in spremljanje mora pote- 
kati v avtentičnem okolju družine $s$ preučevanjem tehnoloških kontekstov, ki jih vzpostavlja digitalna tehnologija (Bronfenbrenner, 1979; Plowman, 2016; Tudge, Brown in Freitas, 2011). Pri vpeljavi je pomembno načrtovanje za konkretno skupino in okolje, kar zahteva poznavanje dejanskih razmer v družinah in poteka v partnerstvu s starši, ko vzgojitelji skupaj s starši analizirajo stanje in načrtujejo pristope vključevanja v izvedbeni kurikul.

Kot sedmo obravnavamo načelo inkluzije. Načelo inkluzije v izobraževanju zagotavlja dejavno vključevanje $\mathrm{v}$ učno okolje otrokom $\mathrm{z}$ različnimi potrebami in preferencami. Vzgojitelj je soočen s potrebami po načrtovanju učnega okolja z vključevanjem različnih senzoričnih sistemov, ki bo omogočalo kakovostno učenje vsem učencem. Inkluzija je načelo prilagajanja okolja posameznikom in ne postavlja zahtev po prilagajanju učnemu okolju le za otroka (Opara, 2005). Vključevanje informacijsko-komunikacijske tehnologije rešuje dileme inkluzije na ravni odkrivanja posebnih potreb, načrtovanja kurikula in vzpostavitve učnega okolja (Norwich, 2008, v Istenič Starčič in Bagon, 2014). Od asistivne in kompenzacijske funkcije informacijsko-komunikacijskih tehnologij je bil storjen premik k načrtovanju poučevanja po načelu diferenciacije in individualizacije (Istenič Starčič in Bagon, 2014). V obdobju umetne inteligence se sodobna robotska tehnologija za otroke s posebnimi potrebami vključuje že na predšolski stopnji (Rosanda in Istenič Starčič, 2019). W3C konzorcij, vodilna skupnost na področju internetne dostopnosti, razvija standarde univerzalnega oblikovanja z uresničevanjem temeljnega načela interneta, ki je prav v njegovi dostopnosti za vse (Bernes-Lee, 1997). Standardi vključujejo dostopnost, uporabnost in inkluzijo (W3C, 1997). Raziskave dostopnosti vsebin na spletnih straneh izkazujejo relativno nizko stopnjo dostopnosti, ki jo bo treba v prihodnje še izboljšati (Debevc, Kožuh, Hauptman, Klembas, Lapuh in Holzinger, 2015).

Čeprav je bil v preteklosti digitalni razkorak povezan z dostopnostjo do tehnologije, v sodobnosti pa predvsem s spretnostmi za uporabe tehnologije, ostaja za osebe s posebnimi potrebami tehnični dostop še vedno ovira (Lebeničnik in Istenič Starčič, 2020; Istenič Starčič in Lebeničnik, 2020). Tehnične ovire so socialno konstruirane (oblikovanje učnega okolja) (Kumar in Owston, 2016, v Lebeničnik in Istenič Starčič, 2020), kognitivne (prepričanja), afektivne (stališča) in kontekstualne (pomembnost za posameznika) (Straub, 2009, v Lebeničnik in Istenič Starčič, 
2020). Vzgojitelj naj pri svojem delu izkazuje občutljivost za vzpostavljanje okolja, v katerem se bodo lahko vključevali in izražali vsi otroci, ne glede na posebnosti in potrebe (Opara, 2005).

\section{Vrste igre in izobraževalna tehnologija}

Otrokova tehnološka igra poteka na več načinov. Otrok uporablja orodja in predmete v svojem okolju za epistemično, funkcijsko in ludično igro (Hutt, 1966, Bird in Edwards, 2015). Z igro napreduje na vseh področjih učenja uporabe tehnologije. Plowman, McPack in Stephen (2012) vidijo trojni prispevek digitalne tehnologije k učenju: (1) Razvoj spretnosti za razumevanje funkcionalnosti in interaktivnosti digitalnih medijev kot tudi razvoj sposobnosti za otrokovo manipulacijo leteh. (2) Širitev znanja in razumevanja sveta na različnih kurikularnih področjih ob uporabi programov, spletnih strani in digitalnih knjig. (3) Razvoj afektivnih, socialnih in kognitivnih dispozicij za učenca (Plowman, McPake in Stephen, 2012). Bird in Edwards (2015) analizirata tehnološko epistemično in ludično igro, kot jo opredeli Hutt (1966, v Bird in Edwards, 2015) v kontekstu socialno-kulturne teorije Vigotskega (1987). Na primeru uporabe kamere, tabličnega računalnika in osebnega računalnika analizirata izmenično izvajanje epistemične in ludične igre. Njun pristop smo razširili s funkcijsko igro (Piaget, 1962) in ga v sliki 7 predstavljamo v kontekstu učenja digitalnih spretnosti in dispozicij za učenje (Plowman, McPack in Stephen, 2012). Epistemična igra vključuje raziskovanje in reševanje problemov pri iskanju odgovora na vprašanje: »Kako predmet deluje? «(Hutt, 1966). Funkcijska igra zadeva otrokove senzomotorične sheme (Piaget, 1962). Ludična igra vključuje simbolne, domišljijske in inovativne dejavnosti pri iskanju odgovora na vprašanje: »Kaj s predmetom lahko storim?«(Hutt, 1966). 
Slika 7: Tehnološka igra za razvoj digitalnih spretnosti, umeščenih v kurikularna področja, in dispozicij za učenje na vseh področjih učenja

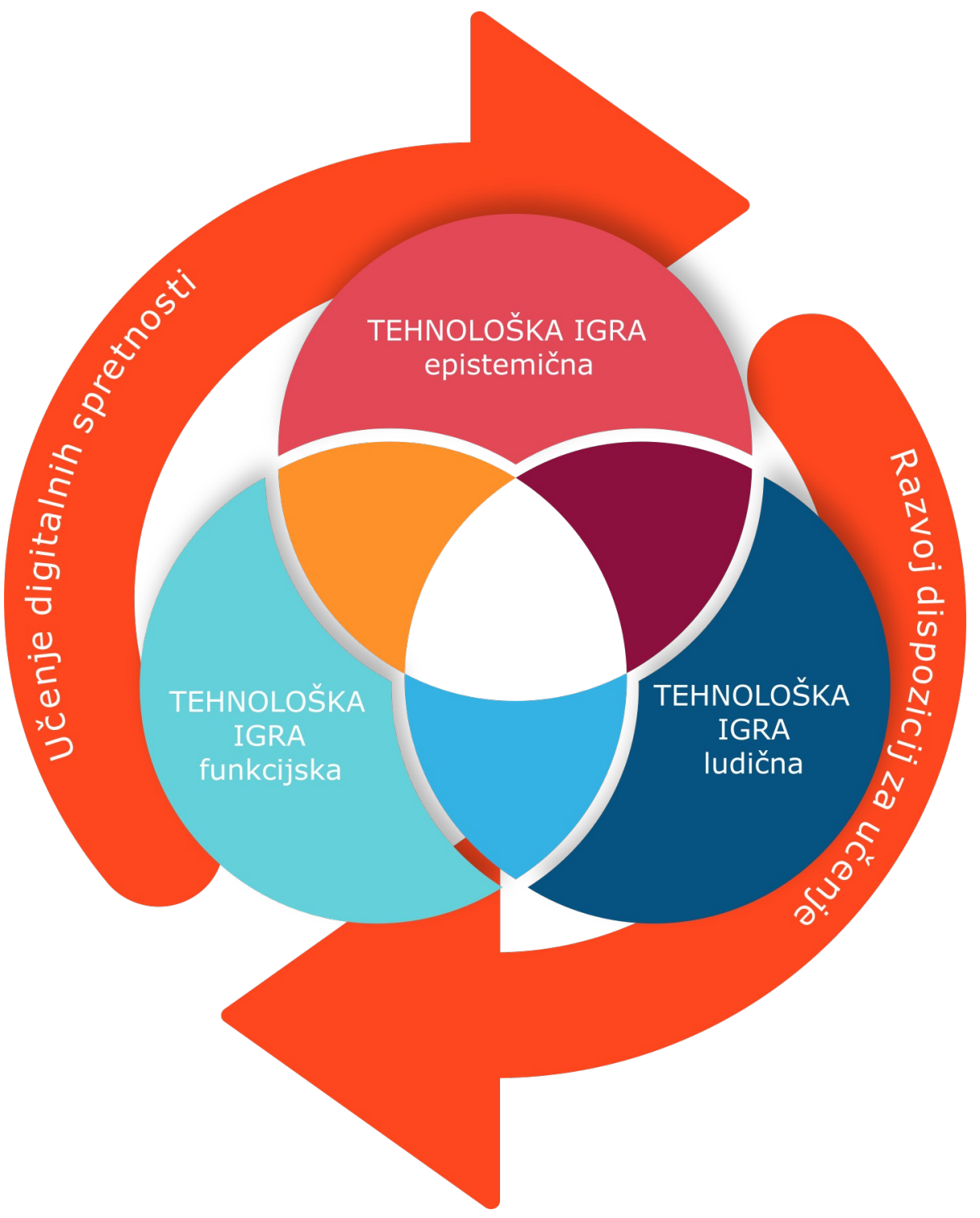

Epistemična igra z raziskovanjem vključuje uporabo in preizkušanje različnih računalniških vmesnikov, preizkušanje računalniških nastavitev in raziskovanje $\mathrm{v}$ različnih aplikacijah. O epistemični igri z reševanjem problemov govorimo, ko otrok rešuje različne probleme ob manipulaciji z napravo ali programom. Pri reševanju 
problemov lahko sodeluje z vrstniki ali odraslimi. Epistemična igra $\mathrm{z}$ razvojem spretnosti obsega tako rokovanje z napravami kot tudi domišljijsko igro z nadomestki naprav ali kosi nedelujočih naprav (denimo tipkovnico, zaslonom). Otrok preizkuša in pri tem tudi namerno izvaja napačne operacije, pri čemer uri svoje spretnosti.

Funkcijska igra poteka ob uporabi različnih programov z vključevanjem različnih senzomotoričnih shem, vida, sluha, grafomotorike, motorike ter koordinacije rok in oči. Otrok uporablja različne digitalne igrače in aplikacije z vmesnikom na dotik za zaznavno gibalno in raziskovalno igro. Raziskuje lastne sposobnosti in sposobnosti predmetov, pri čemer razvija svoje zaznavno-gibalne spretnosti (Marjanovič Umek in Kavčič, 2001).

Simbolna igra vključuje igranje računalniških iger ali uporabo naprav, nadomestkov in nedelujočih kosov naprav v različnih domišljijskih situacijah. Otrok z vključevanjem digitalnih sredstev izvaja različne oblike simbolne igre, pri čemer uporablja različne načine predstavljanja (simboliziranja) predmetov, ki mu omogočajo predmetno ali predstavno transformacijo in prehod od predmetnih aktivnosti $\mathrm{k}$ splošnejši igralni dejavnosti (Marjanovič Umek in Lešnik Musek, 1999, str. 28). Otrok v simbolni igri podoživlja dejanske ali domišljijske izkušnje (Lindon, 2001). Pri igri z digitalnimi sredstvi otrok uporablja virtualne manipulacije z igračami, pri čemer manipulira z zaslonom ali pa kombinira oprijemljive igrače z manipulacijo zaslona.

Otrok lahko igra vlogo odraslega denimo v spletnem bančništvu, spletnem nakupovanju ali z nastopom pred kamero. Računalniške ali internetne aktivnosti oponaša na različne načine. Skupinska simbolna igra lahko poteka ob računalniku na več načinov. Otrok ob igri z vrstniki in z uporabo različnih igrač izvaja raznovrstne izmišljene internetne aktivnosti (videokonferenčni sestanek, virtualno druženje prijateljev). Vsakdanje aktivnosti, značilne za digitalne medije, lahko izvaja brez predmetov, predmet nadomešča $z$ drugim, čustveno in instrumentalno vedenje izraža $v$ namišljenih dejavnostih. Otrok uporablja različne računalniške programe za simbolno igro, denimo pripovedovanje zgodb. 


\section{Izobraževalna tehnologija pri strukturiranju učnih ciljev in ergonomske značilnosti njene uporabe po področjih učenja}

Učni cilji so temeljna sestavina vzgojno-izobraževalnega procesa, ki opredeljujejo vrednostno, snovno in storilnostno dimenzijo vzgojno-izobraževalnih procesov (Kramar, 2009). Učenje je najuspešnejše, ko poteka celostno z aktivacijo vseh področij učenčeve učne aktivnosti. Strmčnik (2001) je opredelil tri osnovne vrste učne aktivnosti: gibalno (kinestetično), čustveno-doživljajsko (afektivno) in umsko (intelektualno). Bruner (1966) področja učenja opredeli kot kognitivno, socialno-afektivno in psihomotorično. Razvil je model učenja na treh stopnjah, ki gredo od konkretne izkušnje prek vizualnih reprezentacij do abstraktnega razumevanja (ibid.). Na predšolski stopnji otrok prehaja med konkretno in vizualno ravnjo.

Ergonomsko načrtovanje otrokovega dela $\mathrm{z}$ računalnikom izraža področja otrokovega učenja in poteka na na fizični, kognitivni in organizacijski ravni. Na psihomotoričnem področju ergonomska obravnava vključuje anatomske, antropološke in psihološke značilnosti otroka. Na kognitivnem področju ergonomska obravnava zadeva vpliv računalniških orodij na miselne procese in interakcijo otroka $\mathrm{z}$ računalnikom in z drugimi osebami. $\mathrm{Na}$ organizacijski ravni, ki zadeva socialno-afektivno področje učenja, ergonomska obravnava vključuje vpliv socialno-tehničnih sistemov in procesov (Karwowski, 2005; Volk idr., 2017). Za ergonomsko preučevanje je zanimiva otrokova uporaba različnih računalniških vmesnikov in primerjava namiznega računalnika in prenosnih naprav. Uporaba miške in tipkovnice poteka na abstraktni ravni. Vmesniki na dotik in oprijemljivi vmesniki se približajo otrokovi manipulaciji predmetov in povezujejo fizično konkretno raven $\mathrm{z}$ vizualnim prikazom na zaslonu. Sodobna tehnologija je prešla prvo fazo miške in tipkovnice, drugo fazo vmesnikov na dotik in na sedanji stopnji razvoja objektnih vmesnikov in interneta stvari (Wiberg, 2017) omogoča ergonomsko prilagoditev potrebam otroka.

Učno aktivnost Ivanuš Grmek in Javornik Krečič (2011) opredelita kot zavestno in ciljno naravnano delovanje, sestavljeno iz raznovrstnih psihofizičnih sestavin, ki je pogoj uspešnega otrokovega razvoja in učne uspešnosti. Avtorji se strinjajo, da je treba digitalno tehnologijo vključevati v zgodnje učenje. Preučujejo, katero tehnologijo vključevati, načine vključevanja ter tudi kdaj je vključevanje digitalne tehnologije lahko neprimerno. Izobraževalna tehnologija v vrtcu zajema tako zaslonsko 
digitalno tehnologijo kot digitalno tehnologijo brez zaslonov. $V$ otrokovo prosto in v vodeno igro vključevanje poteka na več načinov. Vodena igra omogoča pri uporabi digitalne tehnologije mediacijo odraslega, kot so jo opisali Livingstone s sodelavci (2017) in pripomore k ustvarjanju otrokovega območja aktualnega razvoja (Vigotski, 1978). Uporabe digitalne tehnologije z mediacijo odraslega omogoča tudi vodeno odkrivajoče učenje. Uporaba digitalne tehnologije ob vodeni igri ali vodenem odkrivajočem učenju upošteva visoko kompleksnost digitalnih medijev, podpira otrokovo aktivnost in $\mathrm{z}$ različnimi načini interveniranja pri uporabi tehnologije spodbuja razvijanje otrokovih spretnosti. Osrednji cilj vse večjega števila didaktičnih digitalnih iger je razvoj kurikularnih področij, ki so oblikovana za različne vrste igre in za različna razvojna obdobja otroka.

Otrokov razvoj poteka prepleteno na telesnem, gibalnem, kognitivnem, čustvenem in socialnem področju, sprememba na enem področju pa vpliva tudi na druga področja (Videmšek in Pišot, 2007). Gibanje ima velik vpliv na otrokov kognitivni in psihofizični razvoj (Tomporowski, McCullick, Pendleton in Pesce, 2015). Motorični razvoj je umeščen v kulturno okolje, kulturne in socialne izkušnje oblikujejo motorično obnašanje in motorično učenje, ki je povezano $z$ učenjem na drugih področjih (Adolph in Hoch, 2019). Otrok predeluje zunanje dražljaje in zaznavo z lastno domišljijo, vokalizacijo besed ali zvokov in z motoričnim gibanjem (Singer, 1981). Pri uporabi računalnika potrebuje prostor za gibanje, z gibanjem predeluje informacije in vstopa $\mathrm{v}$ interakcijo $\mathrm{z}$ vrstniki in odraslimi. Ob uporabi osebnega računalnika, statičnega na mizi, se otrok giba okoli računalnika. Uporaba tabličnega računalnika otroku omogoča gibanje po prostoru z računalnikom. Didaktični programi naj spodbujajo povezovanje vseh področij učenja in odpravljajo tveganja za gibalni razvoj otroka.

$\mathrm{Na}$ kognitivnem področju učenja je vpeljava izobraževalne tehnologije namenjena opismenjevanju, govorno-jezikovnemu razvoju, matematični pismenosti in razvoju metakognitivnih spretnosti (Yelland, 2005). V ZDA je nacionalno združenje za zgodnje izobraževanje (NAEYC - National Association for the Education of Young Children) že leta 1996 podprlo vpeljavo izobraževalne tehnologije v predšolske izobraževalne ustanove (Rosen in Jaruszewicz, 2009). Obravnava vključevanja tehnologije pri zgodnjem učenju je bila polarizirana (Bowman, 1999). Zagovorniki na 
področju zgodnjega učenja naravoslovja in matematike so vpeljevali izobraževalno tehnologijo na osnovi konstruktivizma, razširjenega v devetdesetih letih 20. stoletja (Bowman, 1999; Clements, 1999). Načela vpeljave vključujejo poudarjeno vlogo vzgojitelja pri izbiri ustrezne programske opreme, vzajemno spodbujanje kognitivnih in socialnih spretnosti otroka, vključevanje računalnikov $v$ povezavi s tradicionalnimi materiali zgodnjega učenja, vključevanje z zagotavljanjem enakih možnosti otrok, uporabo $s$ preseganjem stereotipiziranja posameznikov in skupin, zagotavljanje podpore za usposabljanje in izobraževanje pedagoškega osebja (Yelland, 2005).

Pri vpeljavi dejavnosti, podprtih z digitalno tehnologijo, avtorji opozarjajo na potrebe po osredotočenosti na aktivnosti za razvoj mišljenja, reševanja problemov, učenja učenja, in ne urjenja. V ZDA so že konec devetdesetih let vpeljevali smiselno učenje za nadomeščanje urjenja temeljnih spretnosti brez razumevanja pojmov (Bowman, 1999), uporabo računalnika za razvoj učenja učenja in metakognitivnih spretnosti (Papert, 1980; 1980a), vpeljevali so sodelovalno učenje ob podpori računalni$\mathrm{ka}$ in urjenje $\mathrm{v}$ povezavi s sodelovalnimi in tekmovalnimi nalogami, računalniško vizualizacijo in virtualne reprezentacije za učenje pojmov (Clements, 1999).

Na področju govorno-jezikovnega razvoja podpira digitalna tehnologija pripovedovanje zgodb in interaktivne slikanice. Otrok pripoveduje zgodbo ob ustvarjanju, kjer kombinira tradicionalne in digitalne aktivnosti (Istenič Starčič, Cotič, Solomonides in Volk, 2016).

$\mathrm{Na}$ področju umetnosti digitalna tehnologija podpira likovno, glasbeno in plesno ustvarjanje. Otrok pri likovnem ustvarjanju uporablja različne materiale, pri čemer izkuša njihovo obliko, težo in sestavo. Riše s prsti ali s pripomočki, kar omogoča tudi tablični računalnik. Vmesnik na dotik je bolj intuitiven kot računalnik z miško in tipkovnico, otrok lahko ustvarja z raziskovanjem naravnih senzomotoričnih oblik interakcije (Volk idr., 2016). Oprijemljivi vmesniki omogočajo tudi uporabo predmetov pri interakciji z digitalno vsebino (Istenič Starčič, Cotič in Zajc, 2013).

Alternativni vmesniki podpirajo učenje in razvoj na področju gibalnega razvoja ter omogočajo povezovanje aktivnosti na vseh področjih. V Sloveniji smo imeli že na začetku razvoja didaktičnih programov tudi programe, ki so povezovali področja učenja, denimo kognitivnega z motoričnim za učenje matematike v gibanju. Gibanje 
je sestavni del vsake otrokove aktivnosti in ga je treba podpirati tudi s tehnologijo. Računalniški kotiček ima svoje zakonitosti in zahteva sedenje pred zaslonom, ki majhnemu otroku ne ustreza. Otroci ob računalniku raje stojijo in se gibljejo. Mobilna tehnologija pa omogoča otroku ergonomsko prilagojeno uporabo v gibanju in v različnih položajih.

Otrok se uči v socialnem okolju, v skupini (Vigotski, 1987), zato mu je treba omogočiti sodelovanje z vrstniki. Socialno-afektivno področje učenja obravnavamo kot:

- Vpliv socialne interakcije in čustev pri otroku lahko spodbuja ali zavira učenje. Vzgojitelj spodbuja socialno interakcijo in omogoča oporo pri samozavedanju, socialnem zavedanju, usmerja pozornosti otroka in skupine. Pri otrokovi igri in učenju je pomembna značilnost pozornost otroka, ki jo odražajo samostojnost, ustvarjanje in motivacija v ekspresivnosti in divergentnosti njegove igralne aktivnosti (Ivić, 1981).

- Razvoj socialno-afektivnih spretnosti, ki vključujejo samozavedanje, odgovorno sprejemanje odločitev, socialno zavedanje in odnosne spretnosti (Dusenbury, Yoder, Dermody in Weissberg, 2020).

Uporaba digitalne tehnologije in interneta pri učenju na socialno-afektivnem področju učenja vključuje povezanost čustev z uporabo tehnologije, izražanje čustev $\mathrm{v}$ tehnološko podprti socialni interakciji in razvoj socialno-afektivnih spretnosti. Razvoj socialno-afektivnih spretnosti v tehnološko podprtih okoljih je lahko zavrt. Igra $z$ digitalnimi igračami okrni otrokovo igo, saj ne spodbuja njegove domišljije in izražanja čustev, otrokovo fantazijo nadomeščajo vgrajeni interaktivni mehanizmi, zaradi česar otrok pri igranju $\mathrm{z}$ digitalno igračo tudi ne animira njenih čustev.

Prispevek vzgojitelja pri usmerjanju socialne interakcije in posameznega otroka pri igri in učenju je odvisen predvsem od vzgojiteljevega poznavanja otrokove stvarnosti, ki jo vse bolj sestavljajo interakcije v internetnih okoljih ob uporabi digitalne opreme. Otroška igra in medosebna interakcija z odraslimi v zgodnjem obdobju se z vmesniki na dotik in digitalnimi igračami spreminja. Vzgojitelji in starši potrebujejo strategije uporabe digitalnih medijev in razumevanje okolja, ki ga vzpostavljajo digi- 
talne tehnologije pri spodbujanju učenja z igro. Študije kažejo tveganja na področju socialno-afektivnega učenja in razvoja in so v zadnjih desetletjih identificirale oblike problematične rabe interneta in dejavnike tveganja.

Vzgojitelj ima pomembno vlogo v predšolskem obdobju. Da bi lahko ustrezno podpiral učno razvojne aktivnosti na socialno-afektivnem področju, potrebuje kompetence tudi na področju učinkovanja digitalnih tehnologij, z njim povezanih praks in problematične rabe interneta na otrokov razvoj in učenje. Učitelje je treba na področju problematične rabe interneta usposobiti in jim ponuditi strategije za spodbujanje ustreznega socialno-afektivnega okolja, razvoj spretnosti in zmanjševanje dejavnikov tveganja problematičnih praks. Vzgojitelj lahko pomembno prispeva k ozaveščanju staršev. Obravnava socialno-afektivnega področja razvoja in učenja, podprtega s tehnologijo, in problematične rabe interneta zadeva tudi vključevanje digitalne tehnologije v zgodnje učenje.

\section{Načrtovanje in spremljanje}

Otrokovo razvijanje igre vpliva na razvoj socialnih spretnosti, porajajočih se matematičnih sposobnosti, usvajanje zgodnjih pojmov jezikovne pismenosti in samoregulacije (Leong in Bodrova, 2012). Odrasli pri spodbujanju in vodenju igre upoštevajo več kriterijev (Leong in Bodrova, 2012). Kriterije, ki sta jih naštela Leong in Bodrova (ibid.), obravnavamo v kontekstu vključevanja digitalnih sredstev:

- Načrt igre izraža stopnjo otrokove sposobnosti vnaprejšnjega načrtovanja igre. Vzgojitelj skupaj z otroki oblikuje načrt, spodbuja jih z vprašanji, da oblikujejo temo igre in pravila. Vodenje faze načrtovanja lahko poteka ob risanju in prikazu različnih možnosti in primerov reševanja potencialnih konfliktov. Vzgojitelj lahko uporabi različne programe grafičnega prikaza, animacije in simulacije.

- Vloge in pravila pri igri vlog, ki jih otroci jezikovno in čustveno izražajo. Vzgojitelj otrokom prikaže različne vloge in pripadajoče aktivnosti v vzročno-posledičnem odnosu.

- Objekti, ki jih otrok uporablja v igri, imajo različne stopnje realizma. Uporablja resnične, simbolične in domišlijiske objekte. Vzgojitelj otroke spodbuja 
$\mathrm{k}$ razširjanju repertoarja uporabe posameznega objekta z dejanskim ali domišljijskim preoblikovanjem in dodajanjem funkcij. Možna je uporaba digitalnih značajev, ki jih otrok lahko poljubno oblikuje in relativno hitro preoblikuje.

- Jezik vključuje otrokovo komunikacijo v igri, pri izvedbi različnih scenarijev in usklajevanju medsebojne aktivnosti v igri vlog. Vzgojitelj vpelje otroke v uporabo jezika, značilnega za različne poklice in družbene vloge s prikazom primerov in različnih zgodb ob uporabi digitalnih virov.

- Scenarij obsega teme otroške igre, vključno s sekvencami v igralnem dogodku ali zgodbi in interakcijami med njihovimi vlogami. Razširjeni časovni okvir spremljanja igre zajema daljše časovno obdobje. Potek aktivnosti in dogodkov, ki jih otroci igrajo, zajema različne stopnje. Otroci v igri obravnavajo različne teme, ki jih vedno ne poznajo vedno, in vzgojitelj jih lahko vanje vpelje z raziskovanjem na internetu, $z$ uporabo različnih didaktičnih programov, video- ali zvočnih podkastov.

Vzgojitelj vpeljuje digitalno tehnologijo in pri tem upošteva:

- način uporabe v podporo učenju in razvoju ob upoštevanju otrokovih razvojnih značilnosti,

- povezovanje uporabe s tradicionalnimi aktivnostmi,

- raznolikost izkušenj in povezovanje ter koordinacija z otrokovimi dejavnostmi v družinskem okolju,

- možnosti za igro ob sodelovanju in interakciji,

- za vključenost vzgojitelja/staršev ob njihovi uporabi je pomembna komunikacija med vzgojiteljem/starši in otrokom ter med vrstniki,

- omogočanje zdrave uporabe ob zavedanju zdravstvenih in etičnih dejavnikov,

- prepoznavanje zdolgočasenosti in ustrezno upravljanje občutkov dolgočasja s širjenjem spektra otrokovih interesov,

- krepitev samoregulacije. 
Vzgojitelj opazuje odziv, verbalni, telesni, neverbalni, finomotorični, motorični, stopnjo angažiranosti, $s$ katero se otroci posvečajo nalogi, in razpoloženje posameznika in skupine. Vzgojitelj spremlja in procesno načrtuje dejavnosti. Opazovanje skupine in posameznika narekuje več razlogov, in sicer:

- opazovanje razvoja spretnosti,

- intervencija, ki omogoča ustreznost načina in časa vpeljave dejavnosti,

- individualizacija in diferenciacija za premoščanje razlik med otroki,

- identifikacija interesov in potencialnih spodbud za razvoj otrokovih interesov,

- analiza dejavnosti in njihove ustreznosti, glede na potrebe, interese in motivacijo otroka, kurikularne cilje, skladnost med dečki in deklicami, starostno ustreznost $\mathrm{v}$ heterogenih skupinah,

- izbiranje vrste in stopnje intervencije, spremljanje, podpora, reševanje problemov, zamenjava dejavnosti.

Za vključevanje izobraževalne tehnologije mora vzgojitelj poznati:

- otrokove prakse pri uporabi tehnologije pri igri v družinskem okolju,

- digitalne zaslonske igrače in digitalne igrače brez zaslona,

- načela vključevanja izobraževalne tehnologije,

- priporočila pristojnih organizacij,

- ugotovitve raziskav na nacionalni in mednarodni ravni,

- cilje učenja z digitalno tehnologijo po kurikularnih področjih in priporočenih dejavnostih,

- spretnosti in navade uporabe digitalne tehnologije otrok v skupini ob sodelovanju in partnerstvu s starši.

Vzgojitelj načrtuje vključevanje digitalne tehnologije po korakih:

- Pregleda, kaj ima v vrtcu na voljo, in si pripravi seznam, ki obsega kategorije orodij, razvojno stopnjo ter področja učenja. Pogleda, kaj lahko sam brezplačno pridobi na internetu.

- Izbere razvojni stopnji primerno izobraževalno tehnologijo. 
- Pregleda izbrane tehnologije, oblikuje načrt njihove uporabe in uvede morebitne prilagoditve.

- Upošteva spretnosti otrok in razlike v spretnostih med njimi.

- Načrtuje vključevanje izobraževalne tehnologije glede na cilje v kurikulu z upoštevanjem didaktičnih načel (na primer po načelu individualizacije otrokom postavlja izzive).

\section{Organizacija prostora in omogočanje digitalnih izkušenj}

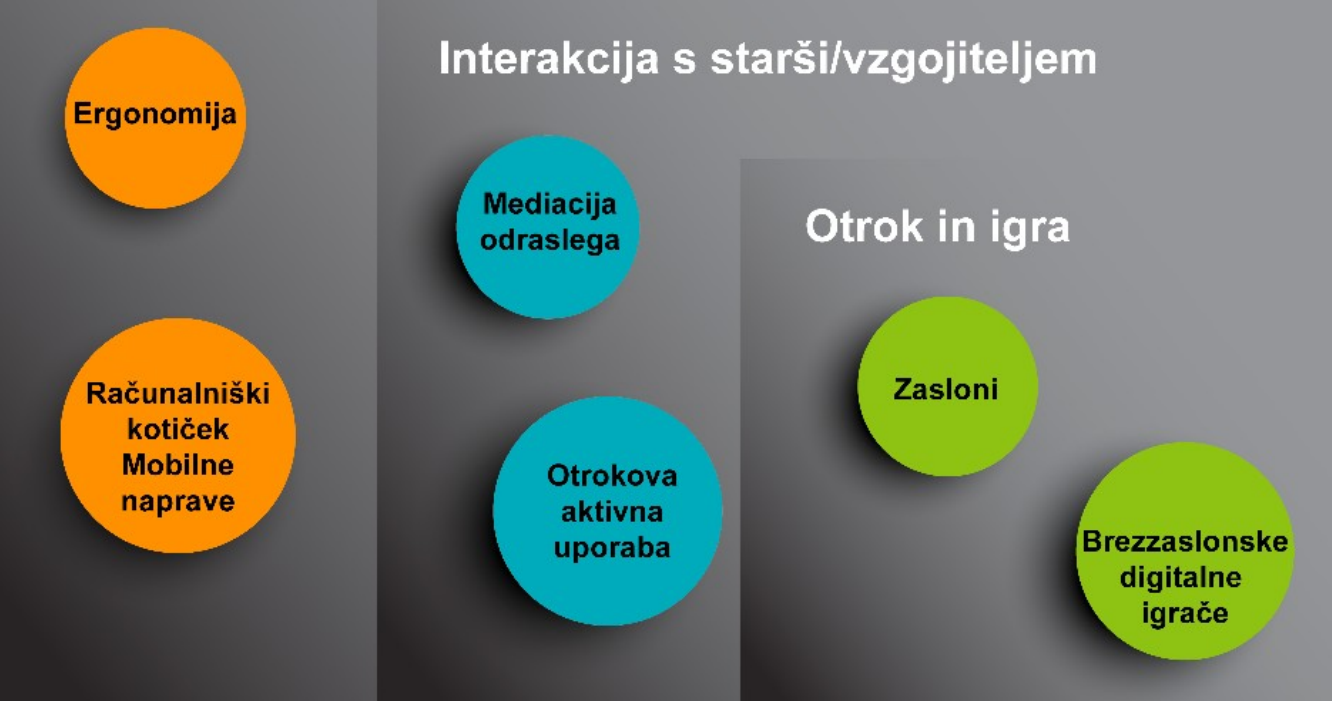

Osredinjenost na tveganja in odtegovanje tesnejšega stika $s$ tehnologijo zanemarja priložnosti digitalnih praks za otrokovo porajajočo se pismenost in za razvoj dispozicij za učenje. Temeljni izziv vključevanju predstavlja premoščanje razkoraka med digitalnimi praksami kot temeljnimi družbeno-kulturnimi praksami, ki jih otrok usvaja z igro. Otrokove digitalne prakse kot igre otroku omogočajo razumevanje kulturnih praks (Edwards, 2013). Digitalne igrače in programi lahko opravljajo 
tudi funkcije prikritega kurikula, zato morajo vzgojitelji in starši kritično pretehtati njihove vsebine in oblike (Edwards, 2015). Ugotovitve raziskav kažejo, da je digitalna igra prisotna na več načinov v vseh vrstah igre. Otroci pri različnih vrstah igre vključujejo junake iz priljubljene medijske produkcije, vključujejo računalnik ali dele računalnika (zaslon, tipkovnica, miška) v igro vlog (računalnik predstavlja službo). Meje med tradicionalno in digitalno igro se brišejo (Marsh, 2010), starši in vzgojitelj imajo pri spodbujanju otrokove digitalne igre pomembno vlogo (Slika 8). 


\section{Digitalno pripovedovanje zgodb}

\section{Pripovedovanje kot učna metoda in opredelitev pojma}

Pripovedovanje je ena izmed oblik metode razlage (Poljak, 1988; Tomić, 1999), ki se od drugih oblik, kot so opisovanje, obrazložitev, pojasnjevanje in presojanje (Poljak, 1988; Blažič idr., 2003), razlikuje po tem, da zadeva predstavitev izmišljene ali reproduktivne zgodbe s poudarjenimi čustvenimi prvinami (Tomić, 1999), z motivacijsko vlogo, napetostjo in privlačnostjo za spodbujanje čustvene zavzetosti (Blažič idr., 2003). Blažič in soavtorji opredelijo vsebinske značilnosti: ustrezna detajliranost, lokaliziranost, aktualnost, sistematičnost, logika in razumljivost. Pripovedovanje zadeva pojave, dogodke, pravila ravnanja in zamisli. Uporablja se na različnih področjih znanosti, leposlovja in umetnosti (Blažič idr., 2003). Avtorji ločijo tri pristope pripovedovanja; epsko z obsežnim in podrobnim pripovedovanjem, lirsko s pripovedovanjem, usmerjenim na čustveno doživljanje, in dramsko pripovedovanje $z$ zapleti (Tomić, 1999; Žagar, 2011). Tradicionalno didaktično je bilo pripovedovanje pojmovano kot akromatska metoda, pri kateri govori učitelj ali učenec (Tomić, 1999). Digitalno pripovedovanje zgodb vključuje poleg ustnega pripovedovanja ene osebe še večkodno, interaktivno komunikacijo z možnostmi vključevanja več oseb.

Pripovedovanje opredeljujejo (1) pripovedni žanri (značilnosti in zakonitosti pripovedovanja znotraj žanrskih zvrsti) in (2) proces komunikacije med pripovedovalcem in pripovedovancem (Zupan Sosič, 2013). Pripovedovanje je pojmovano tudi kot temeljni način govornega sporočanja, značilnega za vsakdanjo komunikacijo. Zupan Sosičeva (ibid., str. 76) opredeljuje pripovedovanje na treh ravneh: kot (1) produkt (zgodbo), (2) temeljno značilnost, obliko (pripoved), (3) postopek in dejanje (pripovedovanje). Vključuje proces in odnos (1) med pripovedovalcem in pripovedovancem, (2) med načinom in predmetom pripovedovanja in (3) med pripovedovalcem in pripovedno strukturo.

Na podlagi zapisanega lahko opredelimo pripovedovanje kot način sporazumevanja/sporočanja, značilnega tako za vsakdanjo komunikacijo, različna žanrska sporočila, kot tudi za vzgojno-izobraževalno komunikacijo, v obliki zgodbe, z vzbujanjem čustvene zavzetosti. 


\section{Preučevanje značilnosti pripovedovanja zgodb in vključevanje v kurikul}

Pripovedovanje zgodb omogoča vzpostavljanje smisla in se izraža $v$ »pripovednem mišljenju«, ki ga je Bruner opredelil kot eno izmed dveh oblik mišljenja poleg racionalnega (Bruner, 2004). Pripovednost je sestavni del percepcije in razlage resničnosti (Zupan Sosič, 2013). Pripovedno mišljenje umešča posameznikovo razmišljanje, spoznavanje in učenje v kontekst motivov, namer, dejavnosti in dosežkov (Marjanovič Umek in Fekonja, 2019, str. 12). Pripovedno mišljenje se razvije že na zelo zgodnji stopnji otrokovega razvoja in spada med otrokova sredstva/orodja učenja in vzpostavljanja odnosa do okolja (Bruner, 1991).

Temeljna značilnost metode pripovedovanja zgodb je fikcija (Tomić, 1999). Pripovedovanje izkorišča ustvarjalno moč domišljije in je otrokovo osnovno orodje, ki ga otrok razvija v domišljijski igri (Vigotski, 1978). Otrok s pripovedovanjem osmišlja in predstavlja svoje izkušnje in poglede (Ahn in Filipenko, 2007). Razvite oblike simbolne igre vodijo v otrokovo ustvarjanje na likovnem in jezikovnem področju. Marjanovič Umek in Fekonja (2019, str. 72-77) otroško igro, risbo in pripovedovanje zgodb opredelita kot povezane dejavnosti, v katerih otrok izraža svoje razumevanje sveta. Otrokova simbolna igra z risbo in pripovedovanjem pogosto temelji na literarni zgodbi in tudi skupinsko obliko simbolne igre ali sociodramske igre otroci izvajajo na osnovi zgodbe (ibid.).

Preučevanje pripovedovanja zgodb Zupan Sosičeva (2013, str. 62-66) obravnava v dveh kontekstih. V okviru opisnega (deskriptivnega) obravnava pripovedovanje kot način organiziranja človeške izkušnje in razmišljanja. V okviru določevalnega (definicijskega) konteksta obravnava strukturne lastnosti pripovedovanja.

Med značilnosti zgodbe v okviru opisnega pristopa šteje:

- prevedljivost zgodbe v različne medije (ustni, pisni, ilustrirani, filmski; pisni ali govorni kanal, jezik, slike ali kretnje; različni žanri),

- zgodba kot oblika vedenja; pripoveduje o tem, kar se je zgodilo, odkriva in izumlja ter interpretira,

- sestavlja razlago v pomenljivo celoto,

- osvetljuje časovnost,

- pripovednost kot sestavni del človeške percepcije in razlage resničnosti, 
- pripoved ima spoznavno, identitetno, performativno in inventivno kategorijo. (ibid.)

V okviru določevalnega pristopa zgodbo strukturirajo:

- časovna ureditev zgodbe (kronološka ali nekronološka),

- načelo verjetnosti ali prepričljivosti,

- kavzalna razmerja,

- splošna načela dogajalnega prostora, literarne osebe in dogodka (ibid.).

Podobno tudi Bruner vzpostavi distinkcijo med preučevanjem pripovedovanja zgodb kot sredstva/orodja spoznavanja, predstavljanja in ustvarjanja znanja in preučevanjem strukture besedila v okviru literarne teorije (Bruner, 2004). V besedilu ne omenjamo teorije dramskega ali likovnega pripovedovanja zgodb, ki ji velja nameniti pozornost $\mathrm{v}$ prihodnje. Transmedijska narava naracije, ki se udejanja v različnih umetnostnih medijih, literarnem besedilu, sliki, filmu ali plesu kot obliki, obravnava posebnosti pripovedovanja $\mathrm{v}$ različnih umetnostnih medijskih oblikah. V zadnjih dveh desetletjih se je pod vplivom G. Kressa in sodelavcev (Kress in van Leeuwen, 2001; Kress in Jewitt, 2003) uveljavil pojem večkodnosti, ki obravnava različne kombinacije kodov izražanja, kot so denimo podobe, besedilo, kretnje in zvok.

Pripovedovanje zgodbe je v zgodnjem razvojnem obdobju povezano z razvojem govornih in spoznavnih zmožnosti in porajajoče se pismenosti, zato ima pomembno vlogo v kurikulu za vrtce (Marjanovič Umek, Fekonja in Pečjak, 2012; Marjanovič Umek in Fekonja, 2019). Pripovedovanje zgodbe je sestavni del govornega razvoja, povezanega $\mathrm{z}$ akademskim opismenjevanjem (ibid.). Pripovedovanje zgodb poteka lahko ustno, pisno, ilustrativno, lutkovno, dramsko.

Pripovedovanje zajemajo splošni in posebni vzgojno-izobraževalni cilji. $\mathrm{Ob}$ uporabi različnih izraznih sredstev so cilji opredeljeni na področju doživljanja, izražanja in ustvarjalnosti, razvoja jezikovnih zmožnosti, prostorskih predstav, vizualizacije, motoričnih spretnosti, razvoja čustvene inteligence, kritičnega mišljenja in spoznavanja kulturne dediščine (Učni načrt za likovno vzgojo (Kocjančič, 2011), Učni načrt za glasbeno vzgojo (Holcar, 2011), Učni načrt za slovenščino (Poznanovič Jezeršek, 2018)). 
Učni načrti omenjajo med splošnimi in posebnimi učnimi cilji pripovedovanja ustvarjalnost in kritično mišljenje, ki sta poleg komunikacije in sodelovanja med kompetencami učenja in inoviranja (P21, 2010; 2012). Ustvarjalnost, kot spretnost in odnos pri ustvarjanju idej, izdelkov ali novih vpogledov, omogoča izvirne, nepričakovane nove rešitve na različnih področjih človekovega delovanja (Sternberg, 2005). Učenje v različnih kontekstih pripovedovanja zgodb omogoča ustvarjalnost kot sposobnost mišljenja (Torrance, 1972), izražanja lastnega interesa (Yang, 2012), samoaktualizacije (Maslow, 1976) in udejstvovanja (Joas, 1996).

Na področju izobraževanja imamo več namenov pripovedovanja, denimo osebne zgodbe pri razvoju in refleksiji identitete, angažirane zgodbe za aktiviranje različnih skupin, razvijanje različnih vrst pismenosti (Istenič Starčič idr., 2016), reševanje dilem, konfliktov, antagonizmov, soočanje pogledov in razbijanje napačnih pojmovanj. Uporabljamo različne vrste zgodbe; zgodbe, usmerjene v osebno izkušnjo, izmišljene zgodbe, zgodovinske zgodbe, zgodbe, $s$ katerimi poustvarjamo literarna in druga umetnostna dela. Pri pripovedovanju zgodb lahko uporabimo različne žanre. Pogosto so v uporabi kratke zgodbe, ki jih Gutierrez (2015) razvrsti po zasnovi zgodbe: zgodba, zasnovana na primeru; zgodba, zasnovana na problemu; zgodba, zasnovana na scenariju; zgodba, zasnovana na naraciji. Zgodba, zasnovana na naraciji, ne predvideva učenčeve aktivne vključitve, medtem ko scenarij simulira resničnost, $v$ kateri učenci pridejo do spoznanj na podlagi preizkušanja (Gutierrez, 2015). Pripovedovanje zgodb poteka $\mathrm{v}$ različnih socialnih oblikah, $\mathrm{v}$ izvedbi učitelja, učencev, $\mathrm{v}$ sodelovanju učitelja in učencev in ob uporabi različnih komunikacijskih kodov.

Pripovedovanje zgodbe je uveljavljeno na vseh disciplinarnih področjih. Navedli smo primere iz učnih načrtov jezika in književnosti ter umetnosti, vendar se uporablja tudi pri poučevanju družboslovja, matematike in naravoslovja, za razbijanje napačnih pojmovanj in za razvijanje pojmov. $\mathrm{V}$ dobi hitrega napredka in znanstvenih odkritij se tudi vodilni znanstveniki usposabljajo za uporabo tehnike pripovedovanja zgodb pri širjenju novih spoznanj v družbi (Green, Grorud-Colvert in Mannix, 2018).

$\mathrm{Na}$ socialno-afektivnem področju učenja skozi doživljanje zgodbe (na domišliijski ravni ali skozi doživljanje lastne ali junakove kontekstualne situacije) in skozi za- 
vzetost, ki jo sproži pripovedovalec, spodbuja čustvene odzive, empatijo, identifikacijo in socialno interakcijo. Čustvena zavzetost in zmožnost zgodbe, da poslušalca preneseta $v$ svet zgodbe, spodbujata učenje (ibid.).

$\mathrm{Na}$ kognitivnem področju pripovedovanje zgodbe z vpeljavo konteksta, vzročnih povezav, predstavitev različnih perspektiv in vpogledov omogoča razvoj znanja (Istenič Starčič idr., 2016; Istenič Starčič, Huang, Valeeva, Latypova, in Huang, 2017). Osmišljanje z zgodbo omogoči pripovedni kontekst, ki vzbuja čustveno zavzetost. Pripovedovalec se uči ob pripovedovanju (osebna zgodba, refleksija in pripovedovanje, ki zasleduje vnaprej opredeljene cilje). Poslušalci se učijo nadomestno s pomočjo izkušenj pripovedovalca zgodbe (Green, Grorud-Colvert in Mannix, 2018).

Pripovedovanje zgodbe vključuje različne aktivnosti ob vključevanju raznolikih izraznih sredstev. Psihomotorično področje je pri zgodnjem učenju morda bolj izraženo, saj otrok spoznava in se uči z gibom. Teorija utelešene kognicije je poudarila vlogo motorike pri spoznavanju in učenju, relevantnem za vsa obdobja učenja. Vključevanje giba skozi ples, igro, lutke, pri nastopu ali predstavitvi za različne priložnosti je $\mathrm{v}$ različnih zgodovinskih obdobjih način ali sestavni del pripovedovanja zgodb.

\section{Pristopi in oblike pripovedovanja zgodb}

Pripovedovanje zgodbe je osebna interpretacija, usmerjena na osebno izkušnjo, bodisi pripovedovalca ali občestva. Tako pripovedovanje, nastanek zgodbe kot sprejem pri občestvu in interpretacija zgodbe so osebna izkušnja. Interakcija med pripovedovalcem in občestvom je sestavni del pripovedovanja zgodbe.

V vzgojno-izobraževalnem procesu pripovedovanje zgodbe omogoča uresničevanje enega ključnih ciljev spodbujanja motivacije in zavzetosti učenca pri osebni interpretaciji znanja. Učenje poteka z osebnim osmišljanjem v znanih kontekstih. Pripovedno mišljenje omogoča vzpostavitev konteksta na več načinov: kontekst vzpostavlja pripovedovalec učitelj z zgodbo, ustrezno razvojni stopnji učencev. Pripovedovalec je sam učenec, lahko pa tudi učitelj in učenec v sodelovanju. 
Značilnosti in proces pripovedovanja zgodbe sledijo razvojni stopnji otroka. Pripovedovanje zgodbe v zgodnjem otroštvu je povezano z razvojem teorije uma, $\mathrm{v}$ okviru katere otrok razume lastna mentalna stanja, kot so želje, namere, prepričanja in mentalna stanja drugih oseb. Teorija uma otroku omogoča strukturiranje zgodbe (Marjanovič Umek in Fekonja, 2019, str. 14.).

Značilnosti pripovedovanja zgodbe, usmerjene v osebno izkušnjo (Ochs, 2004):

- Predstavlja dogodek v časovnem in vzročnem kontekstu.

- Za doseganje narativne pozornosti uporabimo neobičajni ali nepredvideni dogodek kot jedro zgodbe.

- Ko predstavljamo pretekli dogodek ali napovedujemo dogodek v prihodnosti, osebno izkušnjo organiziramo v časovni perspektivi.

- Transformacija osebne izkušnje v različne pripovedne strukture je temeljna človeška značilnost.

- Osebno doživljanje lahko dosegamo na dva načina (s predstavitvijo nepričakovanega ali z izpostavitvijo dileme).

- Uporaba avtentičnega konteksta.

- Prikaz koherentne logike razvoja dogodka ali uporaba alternativne organizacije.

- Uporaba različnih zvrsti.

- Naracija osebne izkušnje v petih dimenzijah (raznolikost junakov, pripovedovalci, jedro $v$ nepredvidenem dogodku, umeščenost $\mathrm{v}$ kontekst, ki je relevanten za občestvo, linearnost, moralni nauk.

- Narativne izkušnje spodbujajo samozavedanje prek delovanja, občutenja, razmišljanja junakov.

\section{Značilnosti digitalnega pripovedovanja zgodb}

Vse bolj se uveljavlja digitalno pripovedovanje zgodb. Poteka ob uporabi različnih naprav in programskih orodij. V družbenih omrežjih je pripovedovanje zgodb integrirano $\mathrm{v}$ vzpostavljanje online samopredstavitve, $\mathrm{s}$ čimer razvija identiteto in digitalne kompetence ter postaja način interakcije in izražanja mladih generacij. Komunikacija vključuje visoko stopnjo sestavljenosti besednih, vizualnih in drugih podatkov, ki se uporabljajo in so značilni za različne kulturne kontekste. Vključevanje 
različnih izraznih kodov: slika, zvok, video ob statični in dinamični, linearni in prostorski predstavitvi je podprto s sodobnimi tehnologijami. Kress in Jewitt preučujeta, kako se večizrazna ali večkodna besedila vključujejo v kurikul pri različnih predmetih in kako se spreminja narava učnih virov z odmikom od tiskane knjige v prehodu na medij zaslona (Kress in Jewitt, 2003). Obravnava besedila zajema večkodno izražanje in prehod od statičnega besedila $\mathrm{k}$ dinamični vizualizaciji in interakciji.

Gibanje pedagogika večrazsežnostne ali sestavljene pismenosti preučuje večkodno pismenost $\mathrm{v}$ kontekstu kulturnih praks mladih, ki postajajo vse bolj digitalizirane in tvorijo njihovo identiteto (Cope in Kalanski, 2009). Lankshear in Knobel (2006) spremembe na področju tiskanih knjig in učbenikov, bralnih navad in pristopov pri učenju novih generacij obravnavata $\mathrm{v}$ kontekstu digitalnih praks.

Digitalno pripovedovanje zgodb izkorišča potencial tehnologije za večkodno izražanje, pripovedovanje ob kombiniranju besedila, slike in drugih kodov. Mayerjeva teorija večpredstavnostnega učenja je spodbudila kombinacijo besedila in slike (Mayer, 2001). Digitalna tehnologija omogoča vključevanje dinamične vizualizacije.

Digitalno pripovedovanje zgodb omogoča umeščen razvoj pismenosti, ki je kontekstualizirana $\mathrm{v}$ refleksijo in identiteto, ki sta povezani z digitalnimi praksami (Istenič Starčič idr., 2016).

Metoda digitalnega pripovedovanja zgodb se uporablja $\mathrm{v}$ profesionalnem razvoju in pedagoškem delu učitelja. Pri profesionalnem razvoju digitalno pripovedovanje zgodb omogoča refleksijo in podpira razvoj profesionalne identitete. Pri pedagoškem delu učitelji pripravljajo učno gradivo, organizirajo aktivnosti učencev, s katerimi ti usvajajo in razvijajo svoje znanje na različnih področjih. Pri izobraževanju in usposabljanju učiteljev metoda digitalnega pripovedovanja zgodb omogoča povezan razvoj kompetenc na tehnološkem, pedagoškem in vsebinskem predmetno specifičnem področju. $V$ začetnem izobraževanju vzgojiteljev in učiteljev sem digitalno pripovedovanje zgodb vpeljala v študijskem letu 2007/08 pri predmetu izobraževalna tehnologija $\mathrm{v}$ študijskih programih predšolske vzgoje in razrednega pouka (ibid.). Pri razvoju kompetenc vzgojitelja in učitelja za uporabo izobraževalne tehnologije pri poučevanju in učenju sem si zastavila dve načeli, ki sta temeljno vodilo tudi po več kot desetletju izvajanja priprave bodočih učiteljev in vzgojiteljev s pomočjo metode 
digitalnega pripovedovanja zgodb: (1) soustvarjanje vzgojitelja/učitelja in otroka in (2) učenje $\mathrm{z}$ raziskovanjem, konstrukcijo in ustvarjanjem ob povezovanju tradicionalnih in digitalnih sredstev.

Pri poučevanju digitalno pripovedovanje zgodb zahteva:

- didaktično, vsebinsko in tehnološko načrtovanje priprave in izvedbo,

- povezovanje različnih področij učenja (kognitivno, socialno-afektivno in psihomotorično),

- vključitev zgodbe kot koherentnega okvira za predstavitev dejstev in njihove znanstvene razlage,

- povezovanje verbalnega in slikovnega, saj slika zmanjšuje kognitivno obremenitev (Mayer, 2001),

- razvoj digitalnih kompetenc in večkodnega oblikovanja,

- razvoj spretnosti kombinacije tradicionalnih in digitalnih sredstev in virov,

- razvoj medosebnih spretnosti in empatije: pri vsakem pripovedovanju je ključen stik med pripovedovalcem in občestvom,

- razvoj sodelovanja in interakcije med učiteljem in učenci in med učenci.

Digitalno pripovedovanje zgodbe $\mathrm{v}$ procesu učenja vpliva na več načinov:

- spodbuja učenje ob povezovanju različnih področij (kognitivno, socialnoafektivno in psihomotorično),

- omogoča vzpostavitev konteksta in odnosov v strukturi pojmov in pojavov,

- spodbuja razvoj pozornosti in spretnosti aktivnega poslušanja,

- spodbuja razvoj jezikovne pismenosti,

- pospešuje sposobnost vizualizacije,

- vzpostavlja kontekst za razvoj smisla in lastnega razumevanja,

- spodbuja razvoj ustvarjalnosti,

- razvija kritično mišljenje,

- spodbuja razvoj sposobnosti reševanja problemov. 


\section{Primer uporabe digitalnega pripovedovanja zgodb pri poučevanju evolucije}

Za poučevanje na področju evolucije je kritično obdobje zgodnjega učenja. Otrok že v zgodnjem otroštvu oblikuje naivne predstave o naravi in živih bitjih, ki so esencialistične in teleološke (Kelemen, Emmons, Schillaci in Ganea, 2014). Učni cilji na področju evolucije so v kurikul umeščeni v obdobju adolescence, ko so predstave že utrjene in zato predstavljajo veliko oviro pri učenju. Težko jih je preoblikovati in nekatere se ohranijo celo v odraslosti.

Ugotovljeno je, da so pri branju zgodb otroci manj obremenjeni s predstavami (Browning in Hohenstein, 2013). Raziskovalci na področju evolucije so za poučevanje napisali domišljijske zgodbe, ki razbijajo napačne koncepte in otroka pripravijo na razmišljanje o pojavih in odnosih. Pripovedovanje zgodb spodbuja otroka $\mathrm{k}$ tvorjenju lastne interpretacije pripovedi in ga pritegne $v$ domišlijijki svet, $v$ katerem je sposoben odmika od znanega in pripravljen za nova spoznanja. Zato lahko zgodbe pomembno prispevajo $\mathrm{k}$ razbijanju napačnih pojmovanj (Browning in Hohenstein, 2013). Domišljijski svet in domišljijski junaki niso zgolj del domišljije, otrok jih vključuje bolj fleksibilno, zanj lahko predstavljajo resničnost (Sharon in Woolley, 2004). Otroci namreč prek zgodb kombinirajo domišljijski in resnični svet in izgrajujejo resničnost (Ahn in Filipenko, 2007). Zgodba omogoča obravnavo pojmov, prilagojeno starosti otroka: daje kohezivni okvir, torej povezano obravnavo dejstev in znanstvene razlage (Kelemen idr., 2014), s slikanico zmanjšuje kognitivno obremenitev in tako upošteva zmožnosti obdelave informacij (Mayer, 2001).

Če povzamemo:

- Pripovedovanje zgodb je otrokov izvirni način interakcije z okoljem in interpretacije pri razvijanju lastnega razumevanja in predstav.

- Pripovedovanje zgodb otroka spodbuja k tvorjenju lastne interpretacije pripovedi.

- Pripovedovanje otroka pritegne v fantazijski svet in mu omogoča odmik od znanega in soočanje z neznanim. Zmožnost lastne interpretacije in odmik od lastnih pojmovanj pripomore $\mathrm{k}$ razbijanju napačnih pojmovanj (Browning in Hohenstein, 2013).

- Zgodba omogoča obravnavo pojmov, prilagojeno starosti otroka. 
- Zgodba daje kohezivni okvir, torej povezano obravnavo dejstev in znanstvene razlage.

- S slikanico zmanjšujemo kognitivno obremenitev in tako upoštevamo otrokove zmožnosti obdelave informacij (Mayer, 2001).

Deborah Kelemen je s sodelavci napisala zgodbo za obravnavo prilagoditve organizmov z naravno selekcijo. Preizkusila jo je v eksperimentu, v katerem so sodelovali otroci med petim in šestim letom starosti ter med sedmim in osmim letom starosti. Otroške naivne predstave o prilagoditvi z naravno selekcijo so oblikovane iz napačnih pojmovanj, ki so skladna s transformističnim pojmovanjem, po katerem pride do transformacije s prilagoditvijo $\mathrm{v}$ obdobju življenja ene generacije (Kelemen idr., 2014). Z eksperimentom je dokazala, da je pripovedovanje zgodb s slikanico spodbudilo razumevanje naravne selekcije in prilagoditve skladno z evolucijsko teorijo in otroke pripravilo na kasnejše učenje na področju evolucije. Zgodba vzpostavlja kohezivni okvir obravnavi znanstvenih spoznanj pri prikazu in utemeljitvi dejstev in znanstvenih razlag (ibid.). $Z$ zgodbo, podprto s slikanico, prikazujemo dejstva $\mathrm{v}$ domišljijskem kontekstu. $\mathrm{S}$ pripovedovanjem zgodbe spodbujamo otroka $\mathrm{k}$ razmišljanju o procesih in pojavih in ga tudi že pripravljamo na razvoj kompleksnih pojmov v njegovem domišljijskem doživljanju sveta. Med najbolj razširjenimi primeri zgodb na temo evolucije je zgodba o Prababici ribi avtorjev Jonathana Tweeta in Karen Lewis (2015), ki vključuje tudi didaktična navodila za uporabo.

Lugmayr in sodelavci so opredelili štiri razsežnosti digitalnega pripovedovanja zgodb, ki so: naracija, perspektiva, interaktivnost, medij. Naracija je artefakt pripovedovanja zgodb, ki spodbuja čustveno zavzetost. Zanjo so značilni kavzalnost, časovnost (kronološko, nekronološko), junaki, pripovedni izraz in struktura (uvod, jedro, zaključek), organizacija (linearna, prostorska) in interpretacija. Perspektiva izraža pedagoško funkcijo skozi ravni in njihove kombinacije: kognitivna in čustvena, upodabljanje in predstavitev in proces kodiranja in dekodiranja. $S$ tehnološkim razvojem je postala temeljna sestavina pripovedovanja zgodb interaktivnost. Interaktivnost vključuje zavzetost pripovedovanja zgodbe, interakcijo z računalnikom, oblikovanje in sprejemanje odločitev o toku pripovedi. Medij se osredinja na tehnologijo in tehnološke značilnosti, kanale, digitalne vsebine in oblike (Lugmayr, Sutinen, Suhonen, Islas Sedano, Hlavacs in Suero Montero, 2017). 
Robin (2008) je opisal sedem ključnih elementov digitalnega pripovedovanja zgodb:

- Gledišče: Kaj je smisel zgodbe in kaj je perspektiva avtorja?

- Dramsko vprašanje: Ključno vprašanje, ki vzbudi in vzdržuje pozornost do konca zgodbe.

- Čustvena dimenzija: Ključne teme, ki zaživijo, spodbujajo zavzetost.

- Osebna izkušnja: Približati zgodbo osebnemu kontekstu.

- Zvočni učinki: Učinek glasbene in zvočne spremljave.

- Ekonomičnost: Razmerje med obsegom in strukturo, ki vzdržuje pozornost in ne preobremenjuje.

- Dinamika: Dinamika zgodbe in hitrost ali upočasnitev za doseganje dramatičnosti.

Istenič Starčič in soavtorji (2016) vključujejo med sestavine digitalnega pripovedovanja zgodb pri učenju matematičnih aritmetičnih problemov vrsto zgodbe, reprezentacijske oblike, številčne podatke in kontekst. Evalvacija digitalnega pripovedovanja zgodb temelji na verbalnih (narativna kohezija, artikulacija matematične problemske zgodbe), vizualnih, prostorskih, avditivnih kriterijih in dinamiki (Istenič Starčič idr., 2016).

Chung (2007) je opisal naslednje korake pri digitalnem pripovedovanju zgodbe: (1) zgodba, (2) zgodboris, (3) produkcija, (3-a) izdelava značajev, (4) evalvacija. Med kriteriji za evalvacijo Chung (2007) združuje narativne sposobnosti in njihovo realizacijo $\mathrm{z}$ večkodnim izražanjem in vzpostavljanjem razmerja med avdio, video, besedilom, podobo, učinki in njihovo povezanostjo v celoto. Pomembna je usklajenost vizualnega in avditivnega glede na namen; podobe spodbudijo razmišljanje, čustva in izražanje stališča; pri pripovedovanju zgodbe je ključen osebni glas (ibid.). 


\section{Povzetek}

Delo Izobraževalna tebnologija in izgradnja avtentičnega učnega okolja v jedro izobraževalne tehnologije postavlja izboljšanje uspešnosti vzgojno-izobraževalnega procesa. Izobraževalna tehnologija je obravnavana $\mathrm{v}$ globalnem sistemu dejavnikov vzgojno-izobraževalnega procesa, saj ima pomembno vlogo pri povezovanju poučevanja v vzgojno-izobraževalnih zavodih in učenja v naravnih okoljih. Izobraževalna tehnologija omogoča vzpostavljanje avtentičnega učnega okolja na tri pomembne načine: (1) uporaba digitalnih medijev je za današnje generacije avtentična aktivnost, avtentično okolje socialnega življenja, (2) zaradi zmožnosti sodobne tehnologije se lahko avtentična učna okolja vzpostavljajo s povezovanjem »učilnice« in različnih izvirnih okolij (naravnih in drugih) in (3) »učilnica « z vsemi funkcijami se lahko vzpostavi v različnih izvirnih okoljih. $\mathrm{V}$ pričujočem delu je obravnavano zgodnje učenje, ki postaja vse bolj prežeto z digitalno tehnologijo v primarnem okolju družine, ki posega $v$ razmerje med otrokom, interakcijsko vsebino in okoljem, in spreminja interakcijo v družini. Skrb za otrokov razvoj in učenje, po poročilih raziskav, sproža polarizacijo, zagovornikov in nasprotnikov. Poudarjanje tveganj in odtegovanje tesnejšega stika s tehnologijo zanemarja priložnosti digitalnih praks za otrokovo porajajočo se pismenost in razvoj dispozicij za učenje. Temeljni izziv vključevanju predstavlja premoščanje razkoraka med digitalnimi praksami kot temeljnimi družbeno-kulturnimi praksami, ki jih otrok usvaja z igro. Ker se meje med tradicionalno in digitalno igro brišejo, je treba tudi v kurikulu za vrtce, ki temelji na igri, vključevati digitalno igro in v partnerstvu s starši vzpostavljati in ohranjati vez med domom in vrtcem. Med ključnimi dejavniki za vključevanje izobraževalne tehnologije v vrtce so stališča in kompetence pedagoških delavcev, ki jih je treba razvijati v začetnem in vseživljenjskem izobraževanju. Možnosti za vključevanje izobraževalne tehnologije so preučevane tudi v strukturi vzgojno-izobraževalnega procesa z vidika dejavnikov učenja, strukturnih in procesnih dejavnikov učenja ter subjektov učnega procesa, učitelja in učenca. Na začetku 20. stoletja je izobraževalna tehnologija zajemala vlogo pripomočkov, učil ali sredstev. Pozneje, pod vplivom komunikacijskih teorij, je bila pojmovana kot nosilec ali posredovalec informacij. V obeh obdobjih je bila v didaktiki vključena med strukturne sestavine vzgojno-izobraževalnega procesa. $\mathrm{Z}$ ra- 
zvojem računalniške tehnologije in pod vplivom kognitivnih teorij učenja in poučevanja se je obravnavi pripomočkov pridružila obravnava načrtovanja in izvajanja procesov. Izobraževalna tehnologija prepleta dva vidika: vidik rabe tehnologije kot strukturne sestavine in vidik oblikovanja učnega procesa (procesne sestavine). V širšem okviru so obravnavane kompetence 21. stoletja, med katerimi tvorijo poseben sklop informacijske, medijske in tehnološke kompetence. V sodobnosti je na področju izobraževalne tehnologije prevladujoči diskurz razvoj digitalnih kompetenc učitelja, ki je nasledil informacijsko pismenost in malce poznejšo medijsko pismenost. Začetki so izraziteje izražali pojmovanje avtonomne pismenosti kot set spretnosti, tehnik in postopkov za uporabo v različnih kontekstih in situacijah. Medijska pismenost je bila že v svojih začetkih obravnavana v socialnih kontekstih, skladna s socialnim konceptom pismenosti. Obravnava digitalne pismenosti zajema dve podmeni: (1) konceptualizacijo digitalne pismenosti v procesu odmika od tehnološkega in informacijskega $\mathrm{k}$ socialnim praksam in (2) transformacijo izvirne pismenosti z medijem pisave, ki se transformira $\mathrm{v}$ večkodno pismenost, in večrazsežnostno pismenost - sestavljeno pismenost $\mathrm{v}$ socialnih praksah. V primerih dobre prakse je predstavljena metoda digitalnega pripovedovanja zgodb, ki sem jo v preteklih letih podrobno preučevala. Metoda pripovedovanja zgodb je razširjena oblika metode razlage, vključena na različnih področjih kurikula. Pripovedovanje zgodb omogoča vzpostavljanje smisla, percepcije in razlage in se izraža v pripovednem mišljenju. Otrok s pripovedovanjem osmišlja in predstavlja svoje izkušnje in poglede ter razvija pripovedno mišljenje. V svoji digitalni obliki pripovedovanje zgodb izkorišča potencial tehnologije za večkodno izražanje in omogoča umeščen razvoj pismenosti, kontekstualiziran $\mathrm{v}$ refleksiji in identiteti, ki je vse bolj povezana z digitalnimi praksami. 


\section{Abstract}

The book Educational Technology and the Construction of an Authentic Learning Environment at the core of educational technology sets out to improve the performance of the educational process. Educational technology is addressed in the global system of factors of the educational process, as it plays an important role in linking teaching in educational institutions and learning in natural environments. Educational technology enables the establishment of an authentic learning environment in three important ways: (1) the use of digital media is an authentic activity for today's generations, an authentic environment of social life, (2) due to the capabilities of modern technology, authentic learning environments can be established by connecting »classroom « and various original environments (natural and other) and (3) a »classroom « with all functions can be established in a variety of original environments. This paper discusses early learning, which is becoming increasingly permeated by digital technology in the primary family environment, affecting the child's relationships, interaction content, and environment, and changing family interaction. According to research reports concern for children's development and learning, triggers polarization, producing both advocates and opponents. Emphasizing the risks and delaying closer contact with technology neglects the opportunities of digital practices for a child's emerging literacy and the development of learning dispositions. A fundamental challenge to inclusion is bridging the gap between digital practices as fundamental socio-cultural practices that the child learns through play. As the boundaries between traditional and digital play are blurred, digital play should also be included in the play-based kindergarten curriculum and a link between home and kindergarten should be established and maintained in partnership with parents. Among the key factors for the integration of educational technology in kindergartens are the attitudes and competencies of pedagogical staff that need to be developed in primary and lifelong learning. This book discuss possibilities for the integration of educational technology the structure of the educational process in terms of learning factors, structural and process factors of learning and subjects of the learning process, teacher and student. In the early 20th century, educational technology took on the role of aids, teaching aids, or resources. Later, under the in- 
fluence of communication theories, it was conceived as a carrier or mediator of information. In both periods, it was included in the didactics among the structural components of the educational process. With the development of computer technology and under the influence of cognitive theories of learning and teaching, the consideration of gadgets has been joined by the consideration of process design and implementation. Educational technology interweaves two aspects: the aspect of using technology as a structural component and the aspect of designing the learning process (process components). This paper discusses the competencies of the 21st century, among which these two aspects form a special set of information, media and technological skills. In modern times, the prevailing discourse in the field of educational technology is the development of digital competencies of the teacher, who succeeded information literacy and a little later media literacy. The beginnings more clearly expressed the notion of autonomous literacy as a set of skills, techniques, and procedures for use in a variety of contexts and situations. Media literacy has already been addressed in social contexts in its beginnings, consistent with the social concept of literacy. The discussion of digital literacy includes two submenus: (1) conceptualization of digital literacy in the process of moving from technological and information practices to social practices and (2) transformation of original literacy with a written medium that transforms into multimodal literacy, and multiliteracy compound literacy in social practices. The book presents the method of digital storytelling, which the author has studied in detail over the years, as an example/case study of good practice. The method of storytelling is an extended form of the method of interpretation included in various areas of the curriculum. Storytelling enables the establishment of meaning, perception and interpretation and is expressed in narrative thinking. Through storytelling, the child makes sense of and presents his or her experiences and views, and develops narrative thinking. In its digital form, storytelling exploits the potential of technology for multimodal expression and enables the situated development of literacy, contextualized in reflection and an identity that is increasingly associated with digital practices. 


\section{Imensko kazalo}

A

AAP (American Academy of Pediatrics)

$30,38,44,45$

Adams Becker, S.

6,24

Adolph, K. E.

59

Akyempong, $\mathrm{K}$.

4

Alasuutari, M. 42

Ananthanarayanan, V.

6

Anderson, C. A.

46

Anderson, D. R.

29,44

Anderson, R. H.

Aufderheide, $\mathrm{P}$.

9

Australian Government Department of Health

B

Bagon, $\check{S}$.

54

Bahovec, E. D.

48,51

Ball, S.

23

Bandura, A.

29,46

Barr, D.

5

Barr, R.

23

Batistič Zorec, M.

Bawden, D.

8,9 
Behrens, S. J.

Bekelman, T. A.

Bellows, L. L.

42, 46

Berčnik, $S$.

41

Bird, J.

$33,36,52,55$

Blažič, $M$.

$1,2,3,17,51,67$

Bleakley, A.

31

Bodrova, E.

$36,52,62$

Bogatz, G. A.

23

Bolstad, R.

34

Bonte, S.

30,32

Bovaird, J. A.

41

Bowman, B. T.

60

Bronfenbrenner, $\mathrm{U}$.

$22,39,42,53,54$

Brown, J.

54

Browning, E.

75,76

Bruce, B. C.

$5,7,21$

Bruner, J.

$58,68,69$

Buckingham, D.

$7,9,10$

C

Canadian Paediatric Society Digital Health Task Force

44

Cerbin, W.

14

Chakroff, J. L.

31,37 
Chamberlin, B.

42

Chaudron, S.

$37,38,40,47$

Cheung, C. K.

4

Christie, J. F.

36,46

Chung. S. K.

77

Clark, L.

$24,28,29,30,31$

Clark, L. S.

42

Clements, D. H.

6,60

Clinton, K. 10

Cohen, A. A. 23

Conery, L. 5

Cook, D. T.

23,29

Cope, B.

7,73

Cotič, $M$.

38,60

Council of Australian Governments

45,50

Cummins, $\mathrm{M}$.

6

D

Danby, S.

Davis, A.

Davis, F. D.

Davis, G. B.

Debevc, $M$.

10,54

Dermody, C.

61 
Devjak, T.

Dewey, J.

5, 21

Dill, K. E. 46

Donham, J. O. 10

Drent, $M$. 12

Driscoll, $\mathrm{M}$. 17

Dusenbury, L. 61

Dwyer, F. 7

E

Eastin, M. S. 30

Edwards, C. P.

41

Edwards, R. $33,36,37,50,52,55,66$

Edwards, S. $24,25,29,32,36,52,66$

Ely, D. P. $17,18,27$

Emmons, N. A. 75

Erstad, O. $7,9,10,26$

Ertmer, P. A. 11

F

Fadel, C.

4

Fekonja, U. $40,49,68,69,72$

Fetler, M.

Fisser, P. 7 
Flewitt, R.

$7,9,10,26$

Folkvord, F.

Freeman, A.

6

Freitas, L.

Friederich, L.

G

Ganea, P. A.

75

Gentile, D. A.

46

Gilster, P.

Golinkoff, R. M. 48

Green, S. J. 30

Greenberg, B.

30

Grizzle, A.

4

Grorud-Colvert, K.

71

Grosman, M.

10,11

Gross, J. F. 10

Guernsey, L. 28

Gulden, T. 25

Gutierrez, K.

70

$\mathrm{H}$

Haight, P. L.

Hall Giesinger, C.

6 
Hannafin, M. J. 19

$\begin{array}{ll}\text { Hannon, P. } & 10\end{array}$

Hao, Y.

Harrison, J.

Hassinger-Das, B. $\quad 48$

Hattie, J. 6

Hatzigianni. M. 11

Hauptman, S. $\quad 54$

Hayne, $\mathrm{H}$. 23

$\begin{array}{ll}\text { Heitink, M. } & 7\end{array}$

Helsper, E. $\quad 30$

Hinske, S. 35

Hirsch, E. $\quad 30$

Hirsh-Pasek, K. $\quad 48$

$\begin{array}{ll}\text { Hobbs, R. } & 8,9\end{array}$

Hoch, J. E.

Hofshire, L. $\quad 30$

$\begin{array}{ll}\text { Hohenstein, J. } & 75,76\end{array}$

$\begin{array}{ll}\text { Holcar, A. } & 70\end{array}$

Holzinger, A. $\quad 54$

Howard-Jones, P. 46

$\begin{array}{ll}\text { Huang, P. S. } & 71\end{array}$

Huang, Y. M. 
Hughes, C. E.

$\begin{array}{ll}\text { Huston, A. C. } & 23\end{array}$

$\begin{array}{ll}\text { Hutt, C. } & 33,55\end{array}$

\section{I}

Ilgaz, H. $\quad 48,49$

$\begin{array}{ll}\text { Islas Sedano, K. } & 77\end{array}$

Issroff, K.

Istenič Starčič, A. $\quad 6,11,12,22,27,38,43,54,60,70,71,73,77$

Ivanuš Grmek, M. 1, 1,58

$\begin{array}{ll}\text { Ivić, I. } & 49,61\end{array}$

$\mathrm{J}$

Jakku-Sihvonen, R. 12

Jaruszewicz, C. $\quad 44,53,60$

$\begin{array}{lr}\text { Javornik Krečič, } M . & 51,58\end{array}$

Jenkins, H. $\quad 10,25,109$

Jewitt, C. 69

$\begin{array}{ll}\text { Jewitt, C. } & 73\end{array}$

$\begin{array}{ll}\text { Joas, H. } & 70\end{array}$

Johnson, D. W. 6

Johnson, J. E. $\quad 36,46$

Johnson, R. T. 6

Johnson, S. L. $\quad 42$ 
Jones

K

Kalaitzidis, I.

Kalantzis, M. 7

Kalaš, I. 14

Karila, K. 42

Karwowski, W. 58

Kelemen, D. 75,76

Kirkup, G.

Kirkwood, A.

Kittredge, A. K. 48

Klahr, D. 48

Klembas, A. 54

Knobel, N.

11,73

Knoche, L. L.

41

Kocjančič, N. F.

70

Koehler, M. J.

12,13

Koh, J. H. L.

5

Koole, M.

13

Kopp, B.

14

Koschmann, $\mathrm{T}$.

5

Kožuh, I.

10,54

Kramar, M.

1,3 
Kress, G.

$10,69,73$

Kroflič, R.

48, 49

Kumar, K. L.

Kupzyk, K. A.

L

Lampe, $\mathrm{M}$.

Lampert, C.

37,38

Land, S.

Lander, K.

11,26

Langhorne, M. J.

10

Lankshear, C.

11,73

Lapuh, J. B.

54

Latypova, L. A.

71

Lebeničnik, $M$.

$6,11,12,22,27,54$

Lee, K. S.

6

Leong, D.

$36,52,62$

Lešnik Musek, P.

57

Levin, J. A.

$5,7,21$

Lewis, K.

76

Lewis, M.

7,10

Lindon, J.

34,57

Livingstone, S.

$30,31,32,42,43,59$

Lugmayr, A.

76, 77 
$\begin{array}{ll}\text { Lull, J. } & 30\end{array}$

Lupiáñez-Villanueva, F. 30

Lye, S., Y.

M

Maccoby, E. E. $\quad 30$

Mannix, H.

Marentič Požarnik, B. 12

Marjanovič Umek L. 34, 40, 48, 49, 57, 68, 69, 72

Marsh, J.

$7,9,10,25,26,36,39,40,66$

$\begin{array}{ll}\text { Mascheroni, G. } & 30\end{array}$

$\begin{array}{ll}\text { Maslow, A. H. } & 70\end{array}$

$\begin{array}{ll}\text { Mayer, R. E. } & 73\end{array}$

McCloskey, M, $\quad 42$

McCullick, B.

McPack, J.

Means, B.

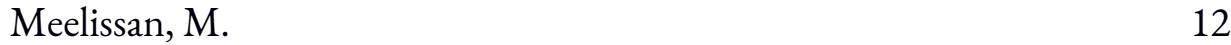

Michnick Golinkoff, R. $\quad 48$

Miguel, H.

$\begin{array}{ll}\text { Mikkola, A. } & 114\end{array}$

$\begin{array}{ll}\text { Mishra, P. } & 12,13\end{array}$

Moore, D. 
Morley, D. 30

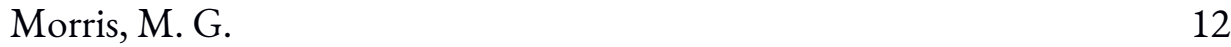

Moura, A. A. $\quad 45$

$\mathrm{N}$

NAEYC (The National Association for the Education

of Young Children) 60

$\begin{array}{ll}\text { Nastasi, B. K. } & 6\end{array}$

Nathanson, A. I. $\quad 30$

$\begin{array}{lr}\text { Niemi, H. } & 12\end{array}$

Norwich, B. $\quad 54$

$\mathrm{O}$

$\begin{array}{ll}\text { Ochs, E. } & 72\end{array}$

Ólafsson, K. $\quad 30$

$\begin{array}{ll}\text { Oliver, K. M. } & 19\end{array}$

Olson, K.

Opara, B. $\quad 54$

$\begin{array}{ll}\text { Ortner, S. } & 22\end{array}$

$\begin{array}{ll}\text { Ottenbreit-Leftwich, A. T. } & 11\end{array}$

Owston, R. $\quad 54$

$\mathrm{P}$

P21 (Partnership for 21st Century Skills) $\quad 4,7,70$ 
Papert, S.

5,60

Pečjak, S.

Pempek, T. A. 29,44

Pendleton, D. M. 59

Pereira, A. F. 45

Pesce, C. 59

Piaget, J. $5,33,55$

Pišot, R. 59

Plowman, L. $3,11,22,24,25,26,28,31,34,37,38,39,50,54,55$

Poljak, V.

Potter, W. J.

Poznanovič Jezeršek, M.

Puentedura, R. R. 12,13

Purushothm, R.

$\mathrm{R}$

Ragan, T. J.

Ramiszowski, A. J. 19

Rautio, P. 32

Redecker, C. 15

Rehmke, D. 10

Reiser, A. R. $1,2,3,17,18,27$

Resman, M. 41

Resnick, L. B. 6 
Reynolds, A.

Rice, $M$. 23

Rideout, V. 41

Ristimaki, E.

Ritchie, L.

7

Robb, M.

$23,28,29,30$

Robin, B. R. 77

Robinson, A. 10

Rosanda, V. 54

Rosen, D. B. 44, 53

Rots, I. 30,32

Rowntree, D.

Russo, C. E.

Sadik, O.

Sefton-Green, J.

$7,9,10,26$

Sendurur, E.

11

Sendurur, P. 11

Serra, J. 45

Sharon, $\mathrm{T}$. 75

Sheehy, K. M. 11,26

Sheridan, S. M. 41

Siddiq, F. 6 
Silverstone, R.

Singer, D. G.

$23,29,46,59$

Smirnova, E.

$36,46,52$

Smith, P. L.

18

Solomon, G.

Solomonides, I. 60

Spencer, $M$.

7

Stahl, G.

5

Stephen, C.

$3,11,24,31,34$

Sternberg, R.

70

Straker, L.

$32,45,47$

Straub, E. T.

54

Street, B.

$6,7,8$

Strijker, A.

7

Strmčnik, F.

$1,5,20,51,58$

Strouse, G. A.

31

Suero Montero, C.

77

Suhonen, J.

77

Süss, D.

37,38

Suthers, D.

5

Sutinen, E.

77

Swaminathan, S.

6 
Šilih, G. $\quad 1,51$

$\begin{array}{ll}\text { Šorgo, A. } & 10\end{array}$

$\mathrm{T}$

$\begin{array}{ll}\text { Tearle, P. } & 12\end{array}$

The New London Group 11

Thompson, D. A. 42

Thorpe, K. 32

Tissari, V. 12

Toličič, I.

$\begin{array}{ll}\text { Tomić, A. } & 67,68\end{array}$

Tomporowski, P. D. 59

$\begin{array}{ll}\text { Tondeur, J. } & 6,12\end{array}$

$\begin{array}{ll}\text { Torrance, E. P. } & 70\end{array}$

Trilling, B.

Troseth, G. L. 31

Tuazon, R. 4

Tudge, J.

Turk, Ž.

$\begin{array}{ll}\text { Turnšek, T. } & 40\end{array}$

$\begin{array}{ll}\text { Tweet, J. } & 76\end{array}$ 
Vaala, S. E.

Valcke, $M$.

$12,30,32$

Valeeva, R. A.

71

Valenčič Zuljan, M.

van Braak, J. $\quad 6$

van Leeuwen, T. 69

$\begin{array}{ll}\text { Veltri, G. } & 30\end{array}$

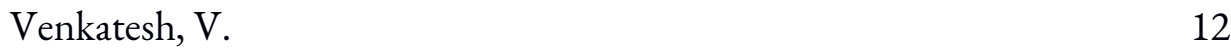

Victoria state government Education and training 19

Videmšek, M.

Vigotski, L.S. $\quad 6,13,24,32,33,48,49,59$

Volk, M.

$38,58,60$

Vukan, M.

W

W3C Web Accessibility Initiative 54

Wartella, E.

$23,28,29,30$

Weigel, $M$.

Weissberg, D. S.

48,49

Weiss, J.

10

Weissberg, R

61

Wener, B.

30,32

Wiberg, $M$.

58 
Wijnen, C. W.

37,38

Wilson, C.

4

Wing, J. M.

4,5

Wohlwend, K.

50

Woolley, J. D.

75

Wright, J. C.

Y

Yang, Y. F.

70

Yelland, N.

$6,50,59,60$

Yilmaz, R. M.

34

Yoder, N.

Z

Zabatiero, J.

Zajc, M.

38,60

Zupan Sosič, A.

67,68

$\check{Z}$

Žagar, D.

67 


\section{Stvarno kazalo}

avdiovizualna komunikacija

$5,17-18,46,50,51$

avtentično učenje

$7,20-21$

didaktika

$1-3,14,17,19,26-27,34,36-37,43,45,48-50,67,74,79$

didaktično načelo

$51-55,65$

digitalna tehnologija

$3,7,10-12,19,21-27,28-66,73-74,77$

digitalno pripovedovanje zgodb

$2,67-78$

ekološko sistemska teorija

22,53

ergonomsko načrtovanje

$38,58,61$

igra

$3,7,14,21,22-37,38,46,48-50,52,55-57,59,61-62,66,68$

igrača

$3,14,24-25,27-29,33-38,44-46,57,61-62,64,66$

internet igrač

34

informacijsko-komunikacijske tehnologije $1-4,7-10,12,15,19,28,40,54,80$

internet

$4-5,7,9,11,19,30,32,34,47,53-54,57-58,61-63,65$

izobraževalna tehnologija

$1-7,11,13,17-22,26-27,31,48-49,51$,

$55,58-60,64-65,74$

kognitivna teorija

$2-3,18,33$

kompetence

$4-9,12-16,32,35,53,62,70,73-74$

komunikacijska teorija

$2-3,18$

konstruktivizem

$5,19,60$

območje aktualnega razvoja

$13,33,49,59$

partnerstvo vzgojitelja s starši

$3,39-43,54,64$ 
pismenost $4-16,26,31,37,39,42,48,50,59,62,65,69-70,73-74$

računalniško podprto sodelovalno učenje $5-6,15,19$ socialno-kulturna teorija $22,24-25,55$

starševska mediacija $24,29-32,37-38,42-45,59$

teorija poučevanja $1,17-18,27$ teorija učenja $1,17-18$ področje učenja $3,50,58,61$ učna aktivnost $8,12-13,51-54,58,63-66$ učna metoda $5,18,26-27,67-68,73-74$ učni cilj $45,58,75$

učno okolje $4,6,19,20-21,27,48-49,53-54$ vrtec $3,14,25-26,31,39-43,48-52,59,65,69$

vzgojitelj $2-3,11-16,26-27,31,37,39-43,46,49,51-55,60-66,74$ 


\section{Literatura}

(American Academy of Pediatrics) committee on public education. (1999). Media education. Pediatrics, 104(2), 341-343. Pridobljeno:

https://pediatrics.aappublications.org/content/104/2/341

AAP (American Academy of Pediatric) committee on public education. (2010). Policy statement - media education. Pediatrics. Pridobljeno:

https://pediatrics.aappublications.org/content/pediatrics/early/2010/09/27/peds.20101636.full.pdf

AAP (American Academy of Pediatrics) committee on public education. (2011). Media use by children younger than two years. Pediatrics. Pridobljeno: https://pediatrics.aappublications.org/content/pediatrics/128/5/1040.full.pdf

AAP (American Academy of Pediatrics) committee on public education. (2016). Council on Communications and Media. Media and young minds. Pediatrics. Pridobljeno: https://pediatrics.aappublications.org/content/pediatrics/138/5/e20162591.full.pdf

Adams Becker, S., Cummins, M., Davis, A., Freeman, A., Hall Giesinger, C., in Ananthanarayanan, V. (2017). NMC Horizon Report: 2017 Higher Education Edition. Austin, TX, USA: The New Media Consortium.

Adolph, K. E., in Hoch, J. E. (2019). Motor Development: Embodied, Embedded, Enculturated, and Enabling. Annual Review of Psychology, 70, 141-64.

Anderson, C. A., Gentile, D. A., in Dill, K. E. (2012). Prosocial, Antisocial, and Other Effects of Recreational Video Games. Chapter in D. G. Singer in J. L. Singer (Ur.), Handbook of Children and the Media, 2nd Edition, 249-272. Thousand Oaks, CA: Sage.

Anderson, D. R., in Pempek, T. A. (2005). Television and very young children. American Behavioral Scientist, 48(5), 505-522.

Aufderheide, P. (1992). Media Literacy: A Report of the National Leadership Conference on Media Literacy. Queenstown Maryland: The Aspen Institute Wye Center.

Australian Children's Education and Care Quality Authority. (2015). Using digital touch technologies to support children's learning. Pridobljeno:

https://wehearyou.acecqa.gov.au/2015/07/15/using-digital-touch-technologies-to-supportchildrens-learning/

Australian Government Department of Health. (2012). Inactivity and screen time. Pridobljeno: http://www.health.gov.au/internet/publications/publishing.nsf/Content/gug-indighb inactivitiy 
Bahovec, E. D., idr. (1999). Kurikulum za vrtce. Ljubljana. Ministrstvo za šolstvo in šport, Zavod Republike Slovenije za šolstvo.

Ball, S., in Bogatz, G. A. (1970). The first year of Sesame Street: An evaluation. Princeton, NJ: Education Testing Service.

Bandura, A. (1977). Social learning theory. New York: General Learning Press.

Barr, D., Harrison, J., in Conery, L. (2011). Computational Thinking: A Digital Age Skill for Everyone. Learning \& Leading with Technology, 38(6), 20-23.

Barr, R., in Hayne, H. (1999). Developmental Changes in Imitation from Television during Infancy. Child Development, 70(5), 1067-1081.

Batistič Zorec, M., in Turnšek, T. (2002). Posredna raven. V: L. Marjanovič Umek, U. Fekonja, T. Kavčič in A. Poljanšek: Ravni, področja in kazalci kakovosti predšolske vzgoje v vrtcu (Ur.) Kakovost v vrtcih, 44-48. Ljubljana: ZIFF.

Bawden, D. (2001). Information and digital literacies; a review of concepts. Journal of Documentation, 57(2), 218-259.

Behrens, S. J. (1994). A conceptual analysis and historical overview of information literacy. College and Research Libraries, 55(4), 309-322.

Bellows, L. L., McCloskey, M., Clark, L., Thompson, D. A., Bekelman, T. A., Chamberlin, B., in Johnson, S. L. (2018). HEROs: Design of a Mixed-Methods Formative Research Phase for an Ecocultural Intervention to Promote Healthy Eating and Activity Behaviors in Rural Families With Preschoolers. Journal of Nutrition Education and Behavior, 50(7), 736-745.

Berčnik, S., in Devjak, T. (2017). Sodelovanje med starši in vzgojitelji v različnih konceptih predšolke vzgoje. CEPS journal, 7(4), 208-226.

Berners-Lee, T. (1997). »World Wide Web Consortium (W3C) Launches International Web Accessibility Initiative."Web Accessibility Initiative (WAI). Accessed June 19, 2010. http://www.w3.org/Press/WAI-Launch.html

Bird, J., in Edwards, S. (2015). Children learning to use technologies through play: A Digital Play Framework. British Journal of Educational Technology, 46(6), 11491160

Blažič, M., Ivanuš Grmek, M., Kramar, M., in Strmčnik, F. (2003). Didaktika. Novo mesto: Visokošolsko središče Novo mesto.

Bolstad, R. (2004). The Role and Potential of ICT in Early Childhood Education: A Review of New Zealand and International Literature. Wellington: Ministry of Education. Pridobljeno: https://www.nzcer.org.nz/system/files/ictinecefinal.pdf

Bowman, B. T. (1999). Dialogue on early childhood science, mathematics and technology education a context for learning: Policy implications for math, science, and 
technology in early childhood education. Pridobljeno:

http://www.project2061.org/publications/earlychild/online/context/bowman.htm

Bronfenbrenner, $U$. (1979). The ecology of human development: experimentsby nature and design. Cambridge, Massachusetts, London, England: Harvard University Press.

Bronfenbrenner, U. (1986). Ecology of the Family as a Context for Human Development: Research Perspectives. Developmental Psychology 22(6), 723-742.

Browning, E., in Hohenstein, J. (2013). The use of narrative to promote primary school children's understanding of evolution. Education 3-13: International Journal of Primary Elementary and Early Years Education, 2, 1-18.

Bruce, B. C., in Levin, J. A. (1997). Educational technology: Media for inquiry, communication, construction, and expression. Journal of Educational Computing Research, 17(1), 79-102.

Bruce, C. (1997). The Seven Faces of Information Literacy Adelaide: Auslib Press.

Bruner, J. (1977). The process of education. Cambridge: Harvard University Press.

Bruner, J. (1991). The Narrative Construction of Reality, Critical Inquiry 18(1), $1-21$.

Bruner, J. (2002). Making Stories: Law, Literature, Life. Cambridge in London: Harvard University Press.

Bruner, J. (2004). Life as Narrative. Social Research, 71(3), 691-710.

Bruner, J. S. (1966). Toward a theory of instruction. Cambridge, MA: Harvard University Press.

Buckingham, D. (2015). Defining digital literacy. What do young people need to know about digital media? Nordic Journal of Digital Literacy, 4, 21-34.

Canadian Paediatric Society Digital Health Task Force. (2017). Screen time and young children: promoting health and development in a digital world. Paediatr Child Health 22, 461-468.

Cerbin, W., in Kopp, B. (2006). Lesson Study as a Model for Building Pedagogical Knowledge and Improving Teaching. International Journal of Teaching and Learning in Higher Education, 18(3), 250-257.

Chakroff, J. L., in Nathanson, A. I. (2008). Parent and school interventions: Mediation and media literacy. V: S. L. Calvert in B. J. Wilson (Ur.), The handbook of children, media, and development, 552-576. West Sussex, UK: Blackwell.

Chaudron, S. (2015). JCR Science and Policy reports, Young children (0-8) and Digital Technology. A qualitative exploratory study across seven countries. Luxembourg: Joint research centre \& Institute for protection and security of children. 
Chung, S. K. (2007). Art Education Technology: Digital Storytelling. Art Education, 60(2), 17-22.

Clark, L. S. (2011). Parental Mediation Theory for the Digital Age. Communication Theory, 21, 323-343.

Clements, D. H. (1999). Young children and technology. In dialogue on early childhood science, mathematics, and technology education. Washington, DC: American Association for the Advancement of Science.

Clements, D. H., Nastasi, B. K., in Swaminathan, S. (1993). Young children and computers: Crossroads and Directions from Research. Young Children, 48(2), 56-64.

Cook, D. T. (2005). The Dichotomous Child in and of Commercial Culture. Childhood 12(2), 155-9.

Cope, B., in Kalantzis, M. (2009). »Multiliteracies«: New Literacies, New Learning, Pedagogies: An International Journal, 4(3), 164-195.

Council of Australian Governments. (2009). Belonging, Being \& Becoming: The Early Years. Learning Framework for Australia. Canberra: Commonwealth of Australia. Pridobljeno:

https://www.acecqa.gov.au/sites/default/files/2018-02/belonging_being_and_becoming_t he_early_years_learning_framework_for_australia.pdf

Davis, F. D. (1989). Perceived Usefulness, Perceived Ease of Use, and User Acceptance of Information Technology. MIS Quarterly, 13(3), 319-340.

Debevc, M., Kožuh, I., Hauptman, S., Klembas, A., Lapuh, J. B., in Holzinger, A. (2015) Using WCAG 2.0 and Heuristic Evaluation to Evaluate Accessibility in Educational Web Based Pages. V: D. Liberona, T. Welzer-Družovec (Ur.), Learning Technology for Education in Cloud. LTEC 2015. Communications in Computer and Information Science, 533, 197-270. Cham: Springer.

Debevc, M., Weiss, J., Šorgo, A., in Kožuh, I. (2020). Solfeggio learning and the influence of a mobile application based on visual, auditory and tactile modalities. British Journal of Educational Technology, 51(1), 177-193.

Dewey, J. (1938). Experience in education. New York: Collier Books.

Dewey, J. (1943). The child and the curriculum: The school and society. Chicago: University of Chicago Press.

Drent, M., in Meelissan, M. (2008). Which factors obstruct or stimulate teacher educators to use ICT innovatively? Computers \& Education 51(1), 187-199.

Driscoll, M. (2000). Psychology of Learning for Instruction. Needham Heights, MA: Allyn \& Bacon. 
Dusenbury, L., Yoder, N., Dermody, C., in Weissberg, R. (2020). An Examination of K-12 SEL Learning Competencies/Standards in 18 States. Pridobljeno: https://casel.org/ wp-content/uploads/2020/03/CSI-Frameworks.pdf

Eastin, M. S., Greenberg, B., in Hofshire, L. (2006). Parenting the Internet. Journal of Communication, 56, 486-504.

Edwards, R. (2015). Software and the hidden curriculum in digital education, Pedagogy, Culture \& Society, 23(2), 265-279.

Edwards, S. (2013). Digital play in the early years: a contextual response to the problem of integrating technologies and play-based pedagogies in the early childhood curriculum. European Early Childhood Education Research Journal, 21(2), 199-212.

Ely, D. P. (1983). The definition of educational technology: An emerging stability. Educational Consideration, 10(2), 2-4.

Ertmer, P. A., Ottenbreit-Leftwich, A. T., Sadik, O., Sendurur, E., in Sendurur, P. (2012). Teacher beliefs and technology integration practices: A critical relationship. Computers \& Education, 59(2), 423-435.

Fekonja, U. (2001). Igrače. V: L. Marjanovič Umek in M. Zupančič (Ur.) Psihologija otroške igre. Razprave Filozofske fakultete. 85-106. Ljubljana: Znanstveni inštitut Filozofske fakultete.

Fetler, M. (1985). Sex differences on the California statewide assessment of computer literacy. Sex Roles, 13, 181-191.

Fisser, P., Heitink, M., in Strijker, A. (2020). Authentic integration of Digital Literacy in education: development of a new curriculum and assessment tool. V: D. Schmidt-Crawford (Ur.), Proceedings of Society for Information Technology \& Teacher Education International Conference (pp. 1205-1215). Online: Association for the Advancement of Computing in Education (AACE). Pridobljeno:

https://www.learntechlib.org/primary/p/215886/

Gilster, P. (1997). Digital literacy. New York: John Wiley.

Green, S. J., Grorud-Colvert, K., in Mannix, H. (2018). Uniting science and stories: Perspectives on the value of storytelling for communicating science. FACETS 3, 164-173.

Greenleaf, R. K. (2003). Motion and emotion. Principal Leadership, 3(9), 14-19.

Grosman, M. (2011). Večrazsežna pismenost izziv sedanjosti. V: M. Cotič, V. Medved Udovič in S. Starc (Ur.), Razvijanje različnih pismenosti, 19-27. Koper: Univerzitetna založba Annales.

Guernsey, L. (2012). Screen time: How electronic media - from baby videos to educational software - affects your young child. Philadelphia, PA: Basic Books. 
Gulden, T. (2015). A system analysis of transmedia storytelling toys in relation to desire and pleasure. Procedia Manufacturing, 3, 2071-2078.

Gutierrez, K. (2015). Keep eLearning Real: 4 Basic Story Types to Link Learning to the Real-World. Pridobljeno: https://www.shiftelearning.com/blog/keep-elearning-real-4basic-story-types-to-link-learning-to-the-real-world

Hannafin, M. J., Land, S., in Oliver, K. M. (1999). Open learning environments: Foundations, methods, and models. V: C. Reigeluth (Ur.), 254 Instructional-design theories and models: Volume II (115-140). 255 Mahwah: Lawrence Erlbaum.

Hao, Y., in Lee, K. S. (2017). Inquiry of pre-service teachers' concern about integrating Web 2.0 into instruction. European Journal of Teacher Education, 40(2), 191-209.

Hattie, J. (2009). Visible learning: A synthesis of meta-analyses relating to achievement. New York, NY, USA: Routledge.

Hatzigianni. M., in Kalaitzidis, I. (2018). Early childhood educators' attitudes and beliefs around the use of touchscreen technologies by children under three years of age. British Journal of Educational Technology, 49(5), 883-895.

Hobbs, R. (2011). The State of Media Literacy: A Response to Potter. Journal of Broadcasting \& Electronic Media, 55(3), 419-430.

Hobbs, R. (2017). Approaches to teacher professional development in digital media literacy education. V: B. De Abreu, P. Mihailidis, A. Lee, J. Melki in J. McDougall (Ur.), International Handbook of Media Literacy Education, 88-113. New York: Routledge.

Holcar, A. (2011). Učni načrt program osnovna šola, glasbena vzgoja. Ljubljana: Ministrstvo za šolstvo in šport, Zavod RS za šolstvo. Pridobljeno: http://www.mizs.gov.si/ fileadmin/mizs.gov.si/pageuploads/podrocje/os/prenovljeni_UN/UN_glasbena_vzgoja.pdf

Howard-Jones, P. (2011). The impact of digital technologies on human wellbeing. Evidence from the science of mind and brain. Oxford, England: Nominet Trust.

Huston, A. C., in Wright, J. C. (1983). Children's processing of television: The informative function of formal features. V: J. Bryant in D. R. Anderson (Ur.) Children's understanding of television, 35-68. New York: Academic Press.

Hutt, C. (1966). Exploration and play in children. Paper presented at the Symposium of the Zoological Society of London, London, England.

Ilgaz, H., Hassinger-Das, B., Hirsh-Pasek, K., in Michnick Golinkoff, R. (2018). Making the Case for Playful Learning. V: M. Fleer, B. van Oers (Ur.), International Handbook of Early Childhood Education, Springer International Handbooks of Education. Cham: Springer Nature Switzerland AG.

Issroff, K., in Scanlon, E. (2002). Educational Technology: The influence of theory. Journal of Interactive Media in Education, 6, 1-13. 
Istenič Starčič, A. (2019). Tehnološko, pedagoško in vsebinsko znanje učitelja ter kurikulum: prispevek na mednarodni znanstveni konferenci Vloga predmetnih didaktik za kompetence prihodnosti, Pedagoška fakulteta Univerze v Mariboru, 4. oktober 2019.

Istenič Starčič, A., in Bagon, Š. (2014). ICT-supported learning for inclusion of people with special needs: Review of seven educational technology journals, 1970-2011. British Journal of educational technology, 45(2), 202-230.

Istenič Starčič, A., Cotič, M., Solomonides, I., in Volk, M. (2016). Engaging preservice primary and preprimary school teachers indigital storytelling for the teaching and learning of mathematics. British Journal of Educational technology, 47(1), 29-50.

Istenič Starčič, A., Huang, P. S., Valeeva, R. A., Latypova, L. A., in Huang, Y. M. (2017). Digital storytelling and mobile learning: potentials for internationalization of higher education curriculum. V: T. C. Huang, R. Lau, Y. M. Huang, M. Spaniol, C. H. Yuen (Ur.) SETE 2017. LNCS, 10676, 400-406. Cham: Springer.

Istenič Starčič, A., in Lebeničnik, M. (2020). Examining the contemporary digital divide of university students with specific reference to students with special educational needs. British Journal of Educational technology, 1-20.

Istenič Starčič, A., in Lebeničnik, M. (2020). Investigation of university students' perceptions of their educators as role models and designers of digitalized curricula. Human technology, 16(1), 55-91.

Istenič Starčič, A., in Turk, Ž. (2016). Ubiquitous learning and digital literacy practices connecting teacher and learner. V: $W W W$ '16 Companion: Proceedings of the 25th International Conference Companion on World Wide Web, 823-827. New York, NY, USA: ACM Digital Library.

Istenič Starčič, A., in Vukan, M. (2019). Teachers' Perception of Data-Driven School Ecosystem and Data Analytics. V: Proceedings of IC4E 2019 (IC4E 2019). Tokyo: Association for Computer Machinery.

Ivanuš Grmek, M., in Javornik Krečič, M. (2011). Osnove didaktike. Maribor: Univerza v Mariboru Pedagoška fakulteta.

Ivić, I. (1981). Igra deteta i njena uloga u razvoju (Zbornik radova 5). Beograd: PA za obrazovanje vaspitačapredškolskih ustanova.

Jenkins, H. (2003). Transmedia Storytelling. Moving characters from books to films to video games can make them stronger and more compelling. MIT Technology Review. Pridobljeno: https://www.technologyreview.com/2003/01/15/234540/transmediastorytelling/

Jenkins, H., Clinton, K., Purushothm, R., Robinson, A., in Weigel, M. (2007). Confronting the challenges of participatory culture: Media education for the 21st century. Chicago IL: The John D. and Catherine T. MacArthur Foundation.

Joas, H. (1996). The creativity of action. Cambridge, Oxford: Polity Press. 
Johnson, D. W., in Johnson, R. T. (1996). Cooperation and the Use of Technology. In D. H. Jonassen (Ed.), Handbook of research on educational communications and technology (1017-1044). New York: Macmillan.

Johnson, J. E., in Christie, J. F. (2009). Play and digital media. Computers in schools, 26(4), 284-289.

Jones, A., Kirkup, G., in Kirkwood, A. (1992). Personal computers for distance education. London: Paul Chapman.

Kalaš, I. (2010). Recognizing the potential of ICT in early childhood education. Analytical survey. Russia: UNESCO Institute for Information Technologies in Education. Pridobljeno: https://unesdoc.unesco.org/ark:/48223/pf0000156769

Karila, K., in Alasuutari, M. (2012). Drawing Partnership on Paper: How do the Forms for Individual Educational Plans Frame Parent - Teacher Relationship? International Journal about Parents in Education, 6(1), 15-27.

Karwowski, W. (2005). Ergonomics and human factors: The paradigms for science, engineering, design, technology and management of human-compatible systems. Ergonomics, 48(5), 436-463.

Kelemen, D., Emmons, N. A., Schillaci, R. S., in Ganea, P. A. (2014). Young children can be taught basic natural selection using a picture-storybook intervention. Psychological Science, 25, 893-902.

Kocjančič, N. F. (2011). Učni načrt program osnovna šola, likovna vzgoja. Ljubljana: Ministrstvo za šolstvo in šport, Zavod RS za šolstvo. Pridobljeno: http://www2.arnes.si/ soppnova/Glavni_okvir/UN_likovna_vzgoja_OS_23-marec2011.pdf

Koole, M. (2009). A model for framing mobile learning. V: M. Ally (Ur.), Mobile learning: Transforming the delivery of education \& training, 25-47. Athabasca: $A U$ Press.

Kramar, M. (2009). Pouk. Nova Gorica: Educa.

Kress, G., in Jewitt, C. (2003). Introduction. V: J. Jewitt \& G. Kress (Eds), Multimodal literacy, 1-18. New York: Peter Lang.

Kress, G., in van Leeuwen, T. (2001). Multimodal discourse: The modes and Media of contemporary communication. London: Arnold.

Kumar, K. L., in Owston, R. (2016). Evaluating e-learning accessibility by automated and student-centered methods. Education Technology Research and Development, 64, 263-283.

Lampe, M., in Hinske, S. (2007). Integrating interactive learning experiences into augmented toy environments. Proceedings of the workshop on pervasive learning 2007, 1-9. Toronto. 
Lander, K., in Sheehy, K. M. (2004). Spatializing literacy research and practice. New York: Peter Lang.

Langhorne, M. J., Donham, J. O., Gross, J. F., in Rehmke, D. (1989). Teaching with computers: a new menu for the '90s. USA: The Oryx Press.

Lankshear, C., in Knobel, M. (2008). New literacies: Everyday practices and clasroom learning (Second edition). Berkshire, England, New York: Open University Press, McGraw-Hill.

Lankshear, C., in Knobel, M. (2011). New literacies, Everyday practices and social learning (Third edition): Berkshire, England, New York: Open University Press, McGraw-Hill.

Lankshear, C., in Knobel, N. (2008). Introduction: Digital literacies: Concepts, policies and practices. V: C. Lankshear in N. Knobel (Ur.) Digital literacies: Concepts, policies and practices. New York, Berlin, Oxford: Peter Lang.

Leong, D., in Bodrova, E. (2012). Assessing and Scaffolding Make-Believe Play. Young Children, 67(1), 28-34.

Lindon, J. (2001). Understanding children's play. Cheltenham: Nelson Thornes Ltd.

Livingstone, S., Ólafsson, K., Helsper, E., Lupiáñez-Villanueva, F., Veltri, G., in Folkvord, F. (2017). Maximizing opportunities and minimizing risks for children online: The role of digital skills in emerging strategies of parental mediation. Journal of Communication, 67(1), 82-105.

Lugmayr, A., Sutinen, E., Suhonen, J., Islas Sedano, K., Hlavacs, H., Suero Montero, C. (2017). Serious storytelling - a first definition and review. Multimedia Tools and Applications, 76, 15707-15733.

Lull, J. (1980). The social uses of television. Human Communication Research, 6(3), 197-209.

Lye, S., Y., in Koh, J. H. L. (2014). Review on teaching and learning of computational thinking through programming: What is next for K-12? Computers in Human Behavior, 41, 51-61.

Maccoby, E. E. (1951). Television: its impact on school children. The public opinion Quarterly, 15(3), 421-444.

Marjanovič Umek, L. in Kroflič, R. (2009). Predšolska vzgoja v vrtcu (Uvodv tematski številki). Sodobna pedagogika, 3, 6-8.

Marjanovič Umek, L., Fekonja, U. (2019). Zgodbe otrok: Razvoj in spodbujanje pripovedovanja. Ljubljana: Razprave Filozofske fakultete.

Marjanovič Umek, L., Fekonja, U., in Pečjak, S. (2012). Govor in branje otrok: Ocenjevanje in spodbujanje. Ljubljana: ZIFF. 
Marjanovič Umek, L., in Lešnik Musek, P. (1999). Otrokov razvoj in učenje v simbolni igri. Psihološka obzorja, 98(1), 25-48.

Marsh, J. (2010). Young Children's Play in Online Virtual Worlds. Journal of Early Childhood Research 8(1), 23-29.

Marsh, J., Hannon, P., Lewis, M., in Ritchie, L. (2017). Young Children's Initiation into Family Literacy Practices in the Digital Age. Journal of Early Childhood Research, 15(1) 47-60.

Mascheroni, G., in Ólafsson, K. (2014). Net Children Go Mobile: Risks and opportunities (2. izd.). Milano: Educatt, Net Children Go Mobile. Pridobljeno: http://netchildrengomobile.eu/reports

Maslow, A. H. (1976). The farther reaches of human nature. An Esalen book. Harmondsworth: Penguin Books. McMillan, S. (1996). Literacy and computer literacy: definitions and comparisons. Computers and education, 27(3-4), 161-170.

Mayer, R. E. (2001). Multimedia learning. Cambridge University Press.

Means, B., in Olson, K. (1995). Technology's role in educational reform. Findings from a National Study of Innovating Schools. Washington, DC: Office of Educational Research and Improvement U.S. Department of Education. Pridobljeno: https://www2.ed.gov/PDFDocs/techrole.pdf

Mishra, P., in Koehler, M. J. (2006). Technological Pedagogical Content Knowledge: A new framework for teacher knowledge. Teachers College Record. 108(6), $1017-1054$.

Moore, D., in Dwyer, F. (1994). Visual Literacy: A Spectrum of Visual Learning. Englewood Cliffs, NJ: Educational Technology Publications.

Nathanson, A. I. (2002). The unintended effects of parental mediation of television on adolescents. Media Psychology, 4(3), 207-230.

NAEYC (The National Association for the Education of Young Children) (1996). Technology and children 3 through 8: A position statement of the National Association for the Education of Young Children. Washington, DC: NAEYC.

NAYEC (The National Association for the Education of Young Children) (2012). Technology and Interactive Media as Tools in Early Childhood Programs Serving Children from Birth through Age 8. Washington, DC: NAEYC.

Norwich, B. (2008). Dilemmas of difference, inclusion and disability. Abingdon: Routledge.

Ochs, E. (2004). Narrative lessons. In Alessandro Duranti (ed.), A companion to linguistic anthropology, 269-89. Malden, MA: Blackwell. 
Opara, B. (2005). Otroci s posebnimi potrebami v vrtcih in šolah: Vloga in naloga vrtcev in šol pri vzgoji in izobraževanju otrok s posebnimi potrebami. Ljubljana: Center Kontura.

Ortner, S. (1984). Theory in Anthropology since the Sixties. Comparative Studies in Society and History, 26(1), 126-166.

Papert, S. (1980). Teaching children thinking: Teaching children to be mathematicians vs. teaching about mathematics. In The computer in the school: Tutor, tool, tutee, ed. R. Taylor, 161-196. New York: Teachers College Press.

Papert, S. (1980a). Mindstorms: children, computers, and powerful ideas New York: Basic Books.

Partnership for 21st Century Skills (P21) \& American Association of Colleges of Teacher Education (AACTE). (2010). 21st century knowledge and skills in educator preparation [White paper]. Pridobljeno:

http://www.p21.org/storage/documents/aacte_p21_whitepaper2010.pdf

Partnership for 21st Century Skills (P21). (2012). Learn for the 21st century: A report and mile guide for 21 st century skills. Pridobljeno: http://www.p21.org/storage/documents/P21_Report.pdf

Piaget, J. (1962). Play, dreams and imitation in childhood. New York: W. W. Norton.

Plowman, L. (2016). Rethinking context: Digital technologies and children's everyday lives, Children's Geographies, 14(2), 190-202.

Plowman, L., McPack, J., in Stephen, C. (2012). Extending opportunities for learning. The role of digital media in early learning. V: S. Suggate in E. Reese (Ur), Contemporary debates in childhood education and development, 95-104. New York, Canada: Routledge.

Plowman, L., McPake, J., in Stephen, C. (2008). Just picking it up? Young children learning with technology at home. Cambridge Journal of Education, 38, 303-319.

Plowman, L., McPake, J., in Stephen, C. (2011). The technologisation of childhood? Young children and technology in the home. Children \& Society, 24(1), 63-74.

Plowman, L., Stephen, C., in McPake, J. (2010). Growing Up with Technology: Young children learning in a digital world. London: Routledge.

Plowman, L., Stephen, C., in McPake, J. (2010a). Supporting young children's learning with technology at home and in preschool. Research Papers in Education, 25(1), 93-113.

Poljak, V. (1988). Didaktika. Zagreb: Školska knjiga.

Potter, W. J. (1998). Media literacy. Thousand Oaks, CA: Sage. 
Poznanovič Jezeršek, M. (2018). Učni načrt (posodobljena izdaja). Program osnovna šola. Slovenščina. Ljubljana: Ministrstvo za šolstvo in šport; Zavod RS za šolstvo. Pridobljeno: https://www.gov.si/assets/ministrstva/MIZS/Dokumenti/Osnovnasola/Ucni-nacrti/obvezni/UN_slovenscina.pdf

Puentedura, R. R. (2013). SAMR: Moving from enhancement to transformation. Pridobljeno:

http://www.hippasus.com/rrpweblog/archives/2013/05/29/SAMREnhancementToTransfor mation.pdf

Ramiszowski, A. J. (1988). The selection and use of instructional media. For improved classroom teaching and for individualized instruction. (2. izd.). London; Kogan page, New York: Nichols Publishing.

Rautio, P. (2013). Children who Carry Stones in Their Pockets: On Autotelic Material Practices in Everyday Life. Children's Geographies, 11(4), 394-408.

Redecker, C. (2017). European Framework for the Digital Competence of Educators. Luxembourg: Publications Office of the European Union.

Reiser, A. R., in Ely, D. P. (1997). The field of educational technology as reflected through its definition Educational Technology Research and Development, 45(3), 63-72.

Reiser, R. A. (2001a). A history of instructional design and technology: Part I: A history of instructional media. Educational Technology Research and Development, 49(1), 53-64.

Reiser, R. A. (2001b). A history of instructional design and technology: Part II: A history of instructional design. Educational Technology Research and Development, 49(1), 57-67.

Resman, M. (1992). Obrati v »filozofiji« sodelovanja med šolo in domom. Sodobna pedagogika, 43(1-2), 28-39.

Resnick, L. B. (1993). Shared cognition: Thinking as social practice. V: Perspectives on socially shared cognition L. B. Resnick, J. M. Levine, S. D. Tealsey (Ur.).

Washington: American Psychology Association.

Reynolds, A., in Anderson, R. H. (1992). Selecting and developing media for instruction. New York: Van Nostrand Reinhold.

Rice, M., in Haight, P. L. (1986). »Motherese " of Mr. Rogers: A description of the dialogue of educational television programs. Journal of Speech and Hearing Disorders, 51, 282-287.

Rideout, V. (2011). Zero to eight: Children's media use in America. San Francisco: Common Sense Media. Pridobljeno: file://C:/Users/astarcic/Downloads/zerotoeightfinal2011.pdf

Ristimaki, E., Niemi, H., Tissari, V., Mikkola, A., in Jakku-Sihvonen, R. (2006). Promoting the Pedagogical Use of ICT in Finnish Universities and Teacher Education 
Programmes. V: R. Jakku-Sihvonen, H. Niemi, (Ur.), Research-Based Teacher Education in Finland: Reflection by Finnish Teacher Educators, 123-150. Turku: Finnish Educational Research Association.

Robin, B. R. (2008). Digital Storytelling: A Powerful Technology Tool for the 21st Century Classroom. Theory Into Practice, 47(3), 220-228.

Rosanda, V., in Istenič Starčič, A. (2019). A review of social robots in classrooms emerging educational technology and teacher education. Education and selfdevelopment, 14(3), 93-106.

Rosen, D. B., in Jaruszewicz, C. (2009) Developmentally Appropriate Technology Use and Early Childhood Teacher Education, Journal of Early Childhood Teacher Education, 30(2), 162-171.

Rowntree, D. (1982). Educational Technology in Curriculum Development. London: Harper and Row.

Sang, G., Valcke, M., van Braak, J., in Tondeur, J. (2010). Student teachers' thinking processes and ICT integration: predictors of prospective teaching behaviors with educational technology. Computers \& Education, 54, 103-112.

Sefton-Green, J., Marsh, J., Erstad, O., in Flewitt, R. (2016). Establishing a research Agenda for the Digital Literacy Practices of Young Children. A White paper for COST action IS 1410. Pridobljeno:

http://digilitey.eu/wp-content/uploads/2015/09/DigiLitEYWP.pdf

Serra, J., Miguel, H., Moura, A. A., Sampaio, A., in Pereira, A. F. (2020). The effect of play task on maternal touch patterns when interacting with their 12 months-old infants: An exploratory study. Infant Behavior and Development. Dostopno: https://doi.org/10.1016/j.infbeh.2020.101438

Sharon, T., in Woolley, J. D. (2004). Do Monsters Dream? Young Children's Understanding of the Fantasy/Reality Distinction. British Journal of Developmental Psychology, 22 (2), 293-310.

Sheridan, S. M., Knoche, L. L., Edwards, C. P., Bovaird, J. A., in Kupzyk, K. A. (2010). Parent engagement and school readiness: Effects of the Getting Ready intervention on preschool children's social-emotional competencies. Early Education \& Development, 21(1), 125-156.

Silverstone, R., Hirsch, E., in Morley, D. (1991). Listening to a long conversation: An ethnographic approach to the study of information and communication technologies in the home. Cultural Studies, 5(2), 204-227.

Singer, J. L., in Singer, D. G. (1981). Television, Imagination, and Aggression: A Study of Preschoolers. London, New York: Routledge.

Smirnova, E. (2011). Character toys as psychological tools. International Journal of Early Years Education, 19(1), 35-43. 
Smith, P. L., in Ragan, T. J. (2000). The impact of R.M. Gagne's Work on Instructional Theory. In Richey, R.C. (Ur.), The legacy of Robert M. Gagne (129-163). Syracuse, NY: RIC Clearinghouse on Information and Technology.

Solomon, G., in Cohen, A. A. (1977). Television Formats, Mastery of Mental Skills, and the Acquisition of Knowledge. Journal of Educational Psychology, 69(5), 612-9.

Spencer, M. (1986). Emergent literacies: a site for analysis. Language Arts, 63(5), $442-53$.

Stahl, G., Koschmann, T., in Suthers, D. (2006). Computer-supported collaborative learning: An historical perspective. $V: R$. K. Sawyer (Ur.), Cambridge handbook of the learning sciences (409-426). Cambridge, UK: Cambridge University Press. Pridobljeno: http://gerrystahl.net/cscl/CSCL_English.pdf

Stapleton, C. B., in Hughes, C. E. (2003). Interactive imagination: Tapping the emotions through interactive story for compelling simulations. IEEE Computer Graphics and Applications, 23(5), 11-15.

Stein, A., in Friederich, L. (1975). Impact of television on children and youth. V: E. M. Hetherington (Ur.). Review of child development research, 5, 183-256. Chicago: University of Chicago Press.

Stephen, C., in Plowman, L. (2014). Digital Play. V: L. Brooker, M. Blaise, S. Edwards (Ur.). SAGE Handbook of Play and Learning in Early Childhood, 330-341. London: SAGE.

Sternberg, $R$. (2005). Creativity or creativities. International Journal of HumanComputer Studies, 63(4-5), 370-382.

Straker, L., Zabatiero, J., Danby, S., Thorpe, K., in Edwards, S. (2018). Conflicting Guidelines on Young Children's Screen Time and Use of Digital Technology Create Policy and Practice Dilemmas. The Journal of Pediatrics, 2002, 300-303.

Straub, E. T. (2009). Understanding technology adoption: Theory and future directions for informal learning. Review of Educational Research, 79(2), 625-649.

Street, B. (1989). Literacy in theory and practice. Cambridge, New York, Port Chester, Melbourne, Sydney: Cambridge University Press.

Street, B. (2005). Understanding and defining literacy. Background paper prepared for the Education for All Global Monitoring Report 2006. Literacy for Life. UNESCO. Pridobljeno: https://unesdoc.unesco.org/ark:/48223/pf0000146186

Strmčnik, F. (1987). Sodobna šola v luči učne diferenciacije in individualizacije. Ljubljana: Zveza organizacij za tehnično kulturo Slovenije.

Strmčnik, F. (2001). Didaktika. Osrednje teoretične teme. Ljubljana: Znanstveni inštitut Filozofske fakultete. 
Süss, D., Lampert, C., in Wijnen, C. W. (2009). Medienpädagogik: ein Studienbuch zur Einführung. Springer.

Šilih, G. (1961). Očrt splošne didaktike. Ljubljana: Državna založba Slovenije.

Šilih, G. (1970). Didaktika. Ljubljana: Državna založba Slovenije.

The New London Group. (2000). A pedagogy of multiliteracies: designing social futres. V: B. Cope in M. Kalantzis (Ur.). Multiliteracies: literacy learning and the design of social futures, 3-37. London: Routledge.

Toličič, I. (1961). Otroka spoznamo v igri. Ljubljana: DZS.

Tomić, A. (1999). Izbrana poglavja iz didaktike. Ljubljana: CPI Filozofska fakulteta.

Tomporowski, P. D., McCullick, B., Pendleton, D. M., in Pesce, C. (2015). Exercise and children's cognition: The role of exercise characteristics and a place for metacognition. Journal of Sport and Health Science, 4, 47-55.

Tondeur, J., van Braak, J., Siddiq, F., in Scherer, R. (2016). Time for a new approach to prepare future teachers for educational technology use: Its meaning and measurement. Computers \& Education, 94, 134-150.

Torrance, E. P. (1972). Predictive validity of the Torrance Tests of Creative Thinking. Journal of Creative Behavior, 6(4), 236-252.

Trilling, B., in Fadel, C. (2009). 21st Century Skills: Learning for Life in Our Times, San Francisco: CA: Jossey-Bass.

Troseth, G. L., Russo, C. E., in Strouse, G. A. (2016).What's next for research on young children's interactive media? Journal of Children and Media, 10, 54-62.

Tudge, J., Brown, J., in Freitas, L. (2011). The Cultural Ecology of Play: Methodological Considerations for Studying Play in its Everyday Contexts. VA. Pellegrini (Ur.) Oxford Handbook of the Development of Play, 119-37. Oxford: Oxford University Press.

Tweet, J., in Lewis, K. (2015). Grandmother fish. A child's first book of Evolution. New York: Feiweland friends.

Vaala, S. E., in Bleakley, A. (2015) Monitoring, Mediating, and Modeling: Parental Influence on Adolescent Computer and Internet Use in the United States. Journal of Children and Media, 9(1), 40-57.

Valcke, M., Bonte, S., Wener, B., in Rots, I. (2010). Internet parenting styles and the impact on internet use of primary school children. Computers \& Education, 55(2), 454-464.

Valenčič Zuljan, M., in Marentič Požarnik, B. (2014). Induction and Early-career Support of Teachers in Europe. European journal of education, 49(2), 192-205. 
van Braak, J., in Tearle, P. (2007). The computer attributes for learning scale (CALS) among university students: Scale development and relationship with actual computer use for learning. Computers in Human Behavior, 23(6), 2966-2982.

Venkatesh, V., Morris, M. G., Davis, G. B., in Davis, F. D. (2003). User Acceptance of Information Technology: Toward a Unified View MIS Quarterly, 27(3), 425-478.

Victoria state government Education and training. (2019). Pridobljeno: https://www.education.vic.gov.au/school/teachers/teachingresources/digital/Pages/ teach.aspx

Videmšek, M., in Pišot, R. (2007). Šport za najmlajše. Ljubljana: Fakulteta za šport.

Vigotski, L. S. (1978). Mind and society. The development of higher psychological process. Cambridge, Massachusetts, London, England: Harvard University Press.

Volk, M., Cotič, M., Zajc, M., in Istenič Starčič, A. (2018). Tablet-based crosscurricular maths vs. traditional maths classroom practice for higher-order learning outcomes. Computers \& Education, 114, 1-23.

W3C Web Accessibility Initiative - WAI. (1997). Dostopno: https://www.w3.org/WAI/fundamentals/accessibility-usability-inclusion/

Wartella, E., in Robb, M. (2011). Historical and Recurring Concerns about children's use of the mass media. V: S. L. Calvert in B. J. Wilson (Ur.), The handbook of children, media, and development, 7-26. West Sussex, UK: Blackwell.

Weissberg, D. S., Hirsh-Pasek, K., Golinkoff, R. M., Kittredge, A. K., in Klahr, D. (2016). Guided Play: Principles and Practices. Current Directions in Psychological Science 25(3) 177-182.

Wiberg, M. (2017). The materiality of interaction. Notes on the materials of interaction design. Cambridge, Massachusetts, London, England: The MIT Press.

Wilson, C., Grizzle, A., Tuazon, R., Akyempong, K., in Cheung, C. K. (2013). Media and information literacy curriculum for teachers. UNESCO. Pridobljeno:

http://www.unesco.org/new/fileadmin/MULTIMEDIA/HQ/CI/CI/pdf/media_and_informat ion_literacy_curriculum_for_teachers_en.pdf $33-35$.

Wing, J. M. (2006). Computational thinking, Communications of the ACM, 49(3),

Wing, J. M. (2008). Computational thinking and thinking about computing. Philosophical Transactions of the Royal Society A Mathematical, Physical and Engineering Sciences. 366(1881), 3717-3725.

Wohlwend, K. (2010). A is for Avatar: Young Children in Literacy 2.0 Worlds and Literacy 1.0 Schools. Language Arts, 88(2), 144-152.

Yang, Y. F. (2012). Multimodal composing in digital storytelling. Computers and Composition, 29(3), 221-238. 
Yelland, N. (2005). The future is now: A review of the literature on the use of computers in early childhood education (1994-2004). AACE Journal, 13(3), 201-232.

Yilmaz, R. M. (2016). Educational magic toys developed with augmented reality technology for early childhood education, Computers in Human Behavior 54, 240-248.

Zupan Sosič, A. (2013). Zgodba, pripoved in pripovedovanje v dvoravninski in troravninski koncepciji pripovedi. Primerjalna književnost, 36(3), 61-83.

Žagar, D. (2011). Didaktika psihologije v srednjem izobraževanju. Ljubljana ZIFF. 


\section{Recenzija - Martin Kramar}

Dr. Andreja Istenič Starčič v delu Izobraževalna tehnologija in izgradnja avtentičnega učnega okolja obravnava položaj in vlogo današnje, sodobne izobraževalne tehnologije v vzgojno-izobraževalnem procesu.

Delo zajema obravnavo naslednjih spletov vprašanja:

- izobraževalna tehnologija za razvoj kompetenc 21. stoletja,

- izobraževalna tehnologija v vzgojno-izobraževalnem procesu: v globalnem sistemu in neposrednem vzgojno-izobraževalnem procesu,

- otrokovo primarno okolje in digitalna tehnologija,

- izobraževalna tehnologija pri strukturiranju vzgojno-izobraževalnega okolja,

- digitalno pripovedovanje zgodb.

Obravnavo posameznih vprašanj in ugotovitve gradi na poznavanju didaktične torije in uporabe sredstev izobraževalne tehnologije $\mathrm{v}$ vzgojno-izobraževalni praksi $\mathrm{v}$ razvitih državah in na lastnih izkušnjah, ki jih avtorica pridobiva $z$ delom v izobraževanju vzgojiteljev in učiteljev.

$\mathrm{V}$ uvodnem delu je na kratko predstavila pojavnost in vključevanje sredstev izobraževalne tehnologije v vzgojno-izobraževalno prakso. Pri tem opozarja na pomemben razvojni premik. Sredstva izobraževalne tehnologije so v vzgojno-izobraževalnem procesu bila prvotno le didaktična sredstva (pomagala) v podporo izvajanju pouka. Tako jih je obravnavala tudi didaktična teorija. $Z$ razvojem tako sredstev IT kot pouka in didaktične teorije je IT postala eden od konstitutivnih dejavnikov pouka, ki ima v današnjih (sodobnih) izobraževalnih praksah vse pomembnejšo vlogo tudi na ravni koncipiranja in artikulacije vzgojno-izobraževalnih procesov. $Z$ razvojem novih funkcij in zmogljivosti sodobnih sredstev informacijske in komunikacijske tehnologije se večata tudi njihova funkcija in vloga $\mathrm{v}$ razvoju izobraževalnih procesov. Ti se razvijajo in spreminjajo vse bolj konsekventno z razvojem izobraževalne tehnologije. Na to vpliva tudi vse večja razširjenost rabe sredstev IKT (informacijsko-komunikacijske tehnologije) v življenju in delu ljudi. Sredstva IKT so tudi pomemben stalni dejavnik $\mathrm{v}$ življenju in delu otrok vseh starosti, razvojnih stopenj oziroma stopenj vzgoje in izobraževanja. Raba pa ni omejena le na dejavnosti, povezane 
z vzgojno-izobraževalnim procesom v vrtcu in šolah, ampak je veliko širša, pestrejša in stalna. Zato vse bolj stopajo v ospredje kompetence za življenje in delo v sedanjih, zlasti pa v prihodnjih razvitih družbah, ki jih sproža vse obsežnejša in redna raba sredstev IKT in njihov razvoj.

Avtorica dela poudarja, da sredstva IT zmorejo izvajanje vse več dejavnosti učenja (in z njimi povezanih drugih dejavnosti), ki so jih v preteklosti izvajali le učitelji oziroma pedagoški delavci. Sprožajo in odpirajo drugačne poglede na organizacijo in potek učenja, na didaktične sisteme vzgojno-izobraževalnega procesa in tudi na vzgojni proces v vrtcu. Odpirajo in širijo se pogledi (in pojmovanja) o pismenosti današnjega človeka, vprašanja medsebojnih odnosov, vodenja in samovodenja učencev.

Povezano s tem ali posledično temu nastajajo novi pojavi, problemi, vprašanja, ki jih pa ta sredstva sama, brez pedagoških delavk in delavcev, ne morejo izpeljati oziroma rešiti.

Avtorica poudarja, da izobraževalna tehnologija spodbuja in sodeluje pri razvijanju kompetenc za 21. stoletje, zlasti tretjega sklopa kompetenc. To so informacijske, medijske in tehnološke kompetence. Med temi so z vidika izobraževalne tehnologije pomembne komunikacijska, informacijska in medijska računalniška in IKT pismenost. IKT k razvoju teh prispeva zelo veliko in je njena vloga nepogrešljiva.

Avtorica je prikazala vlogo in pomen digitalne in medijske pismenosti. Opozorila je na razširjeno pojmovanje in vsebino pismenosti v današnjih razvitih družbah, ki ni več le alfabetska, temveč vedno bolj večkodna. Otroci in učenci spoznavajo in usvajajo digitalno tvorjenje besedil. To je tudi nujno, saj je digitalna pismenost vse bolj razširjena in vse pomembnejši dejavnik - pogoj in dosežek - že v zgodnjem učenju, $v$ šolskem in nadaljnjem, ne le šolskem, izobraževanju.

Avtorica navaja, da sredstva IKT (širše od IT) vplivajo na vsa področja in celotno otrokovo življenje in delo doma. Tako tudi ves čas posredno in neposredno vplivajo na osebnostni razvoj, pri čemer je lahko tudi mnogo spornih, problematičnih in škodljivih vplivov. Avtorica opozarja, da sredstva IKT (IT) v domače življenjsko okolje prinašajo in v njem sprožajo različne pojave, ki škodljivo vplivajo na zdravje, 
na telesni in duševni razvoj otrok. To je treba poznati, se zavedati različnih tveganj in upoštevati priporočila, ki so jih na podlagi empiričnih izkušenj, z opazovanjem in raziskovanjem prakse, izoblikovali strokovnjaki. $\mathrm{V}$ delu so tudi priporočila, ki jih je treba upoštevati v odnosih in rabi sredstev IKT.

$\mathrm{V}$ razdelku izobraževalna tehnologija $\mathrm{v}$ vzgojno-izobraževalnem procesu avtorica IT osvetljuje z didaktičnih teoretičnih opredelitev in strukturiranja vzgojno-izobraževalnega procesa. K temu dodaja, da je v današnjih sodobnih vzgojno-izobraževalnih procesih IT eden nosilnih dejavnikov, pomemben vezni člen med subjekti in strukturnimi ter procesnimi sestavinami tega procesa. V veliki meri omogoča individualizacijo procesa oziroma posamezniško delo učencev.

Predstavila je didaktična načela, ki jih je treba upoštevati pri vključevanju IT v vzgojno-izobraževalni proces. Pojasnila je tudi razmerja med IT in igračami in kako je IT treba upoštevati pri načrtovanju in pripravi neposrednega vzgojno-izobraževalnega procesa.

Delo zaključuje s poglavjem o digitalnem pripovedovanju zgodb. V njem je osvetlila digitalno pripovedovanje zgodb in predstavila digitalno pripovedovanje zgodb na konkretnem primeru.

Delo vsebuje tudi obsežen bogat spisek najnovejše relevantne literature, ki vsebuje spoznanja in ugotovitve različnih teoretičnih znanstvenih preučevanj in (naj)novejših empiričnih raziskav omenjenega področja oziroma problematike.

\section{Sklep}

Prof. dr. Andreje Istenič Starčič v svojem delu Izobraževalna tehnologija in izgradnja avtentičnega učnega okolja obravnava položaj, vlogo in pomembne vidike rabe sredstev didaktične tehnologije pri učenju in v širšem v vzgojno-izobraževalnem procesu. Avtorica poudarja, da je je s tem tesno povezan razvoj človekovih kompetenc za 21. stoletje. Posebej opozarja na sodobno pojmovanje pismenosti in širjenje njene vsebine. Ta je vedno bolj večkodna in zajema komunikacijsko, informacijsko in medijsko računalniško pismenost. 
Predstavila je nova, drugačna, pojmovanja položaja, vloge in pomena izobraževalne tehnologije v vzgojnem in vzgojno-izobraževalnem procesu. Izobraževalna tehnologija ni več le skupek učnih pomagal (orodij), ampak splet pomembnih dejavnikov, ki v vzgojno-izobraževalnem procesu imajo vse večjo in vse pomembnejšo konstitutivno, konceptualno, operativno-izvedbeno in razvojno funkcijo.

Poudarila je, da je izobraževalna tehnologija pomemben splet dejavnikov tudi v celotnem avtentičnem življenjskem, ne le učnem, okolju in s stalno prisotnostjo na vseh področjih življenja in dela otrok tudi nenehno vpliva na učne, razvojne in socializacijske procese otrok oziroma človeka. Pri tem avtorica opozori na pojav tudi različnih motečih in škodljivih vplivov na celoten otrokov razvoj. K temu je dodala tudi priporočila za ravnanje, $s$ katerim škodljive pojave in njihov vpliv lahko zmanjšamo, preprečimo ali celo odpravimo.

Delo je zaključila s prikazom implementacije novih spoznanj o uporabi IT $\mathrm{v}$ zgodnjem učenju in digitalnem pripovedovanju zgodbe.

Delo je pomemben prispevek k teoriji, ki osvetljuje položaj, funkcije in vloge izobraževalne tehnologije pri izboljševanju, modernizaciji in razvoju novih, drugačnih didaktičnih pristopov in procesov v vzgojno-izobraževalni praksi. Opozarja pa tudi na širše okvire in vidike vplivanja izobraževalne tehnologije v človekovem širšem avtentičnem življenjskem okolju.

Delo v veliki meri temelji na mednarodnem kontekstu in primerljivih relevantnih referenčnih tujih delih. Je pomemben prispevek $\mathrm{k}$ temu in primerno za mednarodno diseminacijo ter za prevod $v$ tuje jezike.

$S$ prikazom primera digitalnega pripovedovanja zgodb pa je tudi dobra spodbuda modernizaciji in razvoju neposredne prakse. 


\section{Recenzija - Matjaž Debevc}

$\mathrm{Na}$ osnovi temeljitega pregleda, analize in presoje končnega gradiva za znanstveno monografijo z naslovom »Izobraževalna tehnologija in izgradnja avtentičnega učnega okolja« podajam globalno recenzijsko oceno.

Glede na globalno uveljavljanje tehnologij v vsakdanjem življenju ter predvsem v izobraževanju, kjer se morajo učitelji prilagajati spremembam v praksi, je zelo dobrodošla znanstvena monografija dr. Andreje Istenič Starčič.

Glavni cilj pričujoče znanstvene monografije predstavlja pomen in vlogo izobraževalne tehnologije $\mathrm{v}$ funkciji vzgojno-izobraževalnega procesa ter pri tem raziskuje trende in vplive staršev pri otrokovem osebnem razvoju med procesom izobraževanja. Pri tem raziskuje in izpostavlja didaktično-metodična načela pri uporabi izobraževalnih tehnologij in na izvedbeni ravni izpostavi metodo digitalnega pripovedovanja zgodb s pomočjo izobraževalnih tehnologij.

S takšnim znanstvenim pristopom, strukturo, učinkovitimi ilustracijami, grafi, predstavitvami in uporabo ustreznih pojmov in zakonitosti je avtorica, dr. Andreja Istenič Starčič, ustvarila znanstveno poglobljeno teoretično gradivo o izobraževalni tehnologiji, ki bo zagotovo v pomoč študentom, učiteljem, svetovalcem in odločevalcem v vzgojno-izobraževalnih institucijah.

Pri študiju in prebiranju vsebinskih poglavij je razvidno, da je avtorica na podlagi zunanjih znanstvenih dognanj izpeljala lastna dognanja na področju izobraževalnih tehnologij in metod poučevanja. Iz besedila je prav tako razvidno bogato poznavanje tega področja predvsem z znanstvenega vidika, saj se kaže zelo dobro poznavanje aktualnih teorij in znanstvenih dognanj na področju didaktike in izobraževalne tehnologije, ki se lahko pridobijo samo z dolgoletnimi mednarodnimi izkušnjami, kar avtorica tudi izkazuje.

$\mathrm{Na}$ strokovno dosleden in prepoznaven način prestavi lastna dognanja $\mathrm{z}$ ustrezno strukturiranim argumentom, ki ga gradi v naslednji, lepo prepoznavni strukturi »pomen - uporaba - umestitev v prostor in okolje - izvedba«. 
Pomen izobraževalne tehnologije utemelji s temeljno funkcijo izobraževalne tehnologije pri spodbujanju uspešnosti vzgojno-izobraževalnega procesa, ki se realizira v povezovanju šolskega in družinskega okolja. Zmožnosti sodobne tehnologije znanstveno utemelji v vzpostavljanju avtentičnih učnih okolij, kjer predstavi in utemelji avtentične aktivnosti, značilnosti učnega in družinskega okolja ter upošteva značilnosti udeležencev v učnem procesu.

Avtorica nadalje predstavi ključne zgodovinske razvojne vidike področja izobraževalne tehnologije in kako so spremembe spreminjale odnos šola-družina. Avtorica nato znanstveno utemeljuje, kako je izobraževalna tehnologija presegla vlogo strukturne sestavine vzgojno-izobraževalnega procesa. Pri tem je izpostavila obravnavo načrtovanja in izvajanja pedagoških procesov glede na razvoj računalniške tehnologije skupaj z vplivom kognitivnih teorij učenja in poučevanja.

Uporabo izobraževalne tehnologije je avtorica utemeljila v kontekstu kompetenc 21. stoletja in v kontekstu temeljnih kompetenc vzgojitelja in učitelja. Osvetlila je razvoj opredelitev digitalnih kompetenc učitelja, ki je nasledil informacijsko in medijsko pismenost.

Avtorica v svojem delu zagovarja preseganje pojmovanj v okviru avtonomne pismenosti in nujnost obravnave $\mathrm{v}$ socialnih kontekstih. Obravnavo digitalne pismenosti gradi na dveh podmenah: na konceptualizaciji digitalne pismenosti v procesu odmika od tehnološkega in informacijskega k socialnim praksam in na transformaciji izvirne pismenosti, ki se transformira $\mathrm{v}$ večrazsežnostno pismenost $\mathrm{v}$ socialnih praksah.

Nadalje avtorica $\mathrm{v}$ svojem delu umešča izobraževalno tehnologijo $\mathrm{v}$ širši kontekst otrokovega razvoja. Prikazuje, kako vzgojitelj spremlja in načrtuje otrokove digitalne prakse v partnerstvu s starši ter ugotavlja, kako se meje med tradicionalno in digitalno igro brišejo. Prav tako predstavi, kako je digitalna igra v predšolskem obdobju kot kulturno umeščena dejavnost podlaga pri načrtovanju didaktično-metodičnih pristopov v vrtcu.

Na zadnji, izvedbeni, ravni avtorica svoje delo zaokrožuje s predstavitvijo metode digitalnega pripovedovanja zgodb. Prikazana vsebina o digitalnem pripovedova- 
nju zgodb predstavlja zanimiv primer uporabe izobraževalne tehnologije, ki zajema tehnološki vidik $s$ svojo izdelavo in predstavitvijo zgodbe, kot tudi vse didaktične značilnosti analognega, običajnega, načina tradicionalnega pripovedovanja zgodb.

Skozi celotno besedilo je razvidno, da je avtorica pri svojem znanstvenem pristopu analizirala in obravnavala bogat izbor referenčne literature iz različnih teoretskih znanstvenih preučevanj obravnavane problematike.

Monografija sledi načelu priprave znanstvene monografije, njena kakovost se kaže tudi v že omenjeni analizi in uporabi velikega števila novejše in tuje znanstvene literature ter v ustrezni uporabi strokovno-znanstvene terminologije. Vse skupaj je smiselno integrirano in predstavljeno s spoznanji in določili za slovenski izobraževalni prostor.

Menim, da bo gradivo zelo koristno vsem, ki se ukvarjajo z uporabo izobraževalne tehnologije, še posebej znanstvenikom, študentom, učiteljem pri njihovi analizi, načrtovanju in ocenjevanju možnosti uporabe informacijskih in komunikacijskih tehnologij v izobraževanju. Gradivo bo tudi pripomoček za svetovalce in odločevalce v vzgojno-izobraževalnih procesih. Glede na dejstvo, da je knjiga napisana v mednarodnem kontekstu z uporabo angleškega jezika, bo to prispevalo k dodatni pomembni širši diseminaciji in razširjenosti znanstvene monografije. 


\section{Predstavitev avtorice}

Dr. Andreja Istenič Starčič, redna profesorica za didaktiko, raziskuje in piše o izobraževalni tehnologiji in izobraževanju učiteljev že 18 let. Leta 2002 se je po zaključenem doktorskem študiju zaposlila na Fakulteti za gradbeništvo in geodezijo Univerze v Ljubljani kot vodja kakovosti univerzitetnega študija. Izvajala je tečaje učenja za študente in usposabljanje za visokošolske učitelje. Od leta 2006 sodeluje v raziskovalnem programu e-gradbeništvo. Pedagoško delo izvaja na področju profesionalnega in kariernega razvoja ter praktičnega usposabljanja študentov. Od leta 2005 je zaposlena na Pedagoški fakulteti Univerze na Primorskem. V študijskih programih izobraževanja učiteljev in pedagogike poučuje Izobraževalno tehnologijo, Vzgojo z mediji in za medije, Uporabo računalnika pri pouku otrok s posebnimi potrebami ter Učna okolja formalnega in neformalnega učenja odraslih. Na doktorskem študiju poučuje obvezni predmet Sodobna spoznanja edukacijskih ved. Za doktorski študij je razvila in poučuje tudi več izbirnih predmetov na področju izobraževalne tehnologije - Sodobna okolja za poučevanje in učenje, Informacijsko-komunikacijska tehnologija pri poučevanju in učenju udeležencev s posebnimi potrebami ter Informacijsko-komunikacijska in izobraževalna tehnologija v funkciji spodbujanja ustvarjalnosti. Za svoje uspešno mentorsko delo doktorandom je med finalisti izbora Mentorja leta 2019, ki ga podeljuje Društvo Mlada akademija v sodelovanju z Javno agencijo za raziskovalno dejavnost Republike Slovenije. Leta 2018 je bila gostujoča profesorica na oddelku za izobraževalno tehnologijo na Univerzi Severnega Teksasa. Poučevala je predmet na doktorskem študiju Razširjena učna okolja. V študijskem letu 2012/13 je bila gostujoča raziskovalka na Univerzi Macquarie v Sydneyju, kjer je raziskovala na področju vzpostavljanja osebnega učnega okolja za osebe s posebnimi potrebami. Od leta 2017 je gostujoča profesorica na Univerzi v Kazanu v Rusiji. Od leta 2010 je aktivna v uredniškem odboru British Journal of Educational Technology, do leta 2018 je bila urednica za Evropo, leta 2018 pa tudi odgovorna urednica revije. Sodeluje v uredniških odborih več revij - Educational Technology Research and Development, British Journal of Educational Technology, Journal of Emerging Technologies in Learning in drugih. Je aktivna članica Združenja za izobraževalno Tehnologijo (AECT - Association for Educational Communications 
and Technology) v ZDA, v okviru katere je bila leta 2018 član organizacijskega odbora simpozija o prihodnosti učenja, ki je potekal na Univerzi Severnega Teksasa. Je članica Kitajskega združenja za izobraževalno tehnologijo (SICET) in sodeluje z Univerzo v Pekingu in več univerzami na Tajvanu. Aktivno deluje v Evropski organizaciji za raziskovanje v izobraževanju (EERA - European Educationa Research Association) in Združenju za izobraževanje učiteljev v Evropi (ATEE - Association for Teacher Education in Europe). V EERA je bila ustanovna članica NW27 Didaktika. Je tudi članica Slovenskega društva za raziskovanje v edukaciji (SLODRE) in Britanskega združenja za raziskovanje v izobraževanju (BERA - British Education Research Association). V zadnjih letih raziskuje na področju evalvacije znanosti v družboslovju in humanistiki in je članica EVALHUM - Research Evaluation, Innovation and Impact Analysis for the Social Sciences and Humanities. 


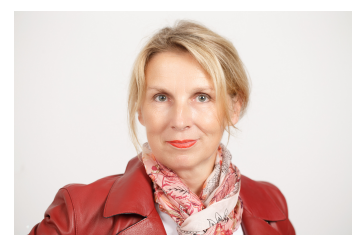

Dr. Andreja Istenič Starčič, redna profesorica za didaktiko, raziskuje in piše o izobraževalni tehnologiji in izobraževanju učiteljev že 18 let. Leta 2018 je bila gostujoča profesorica na oddelku za izobraževalno tehnologijo Univerzi Severnega Teksasa. Poučevala je predmet Razširjena učna okolja. V študijskem letu 2012/13 je bila gostujoča raziskovalka na Univerzi Macquarie v Sydneyju, kjer je raziskovala na področju vzpostavljanja osebnega učnega okolja za osebe s posebnimi potrebami. Od leta 2017 je gostujoča profesorica na Univerzi v Kazanu v Rusiji. Od leta 2010 je aktivna $v$ uredniškem odboru British Journal of Educational Technology, do leta 2018 je bila urednica za Evropo, leta 2018 pa tudi odgovorna urednica revije. Sodeluje v uredniških odborih več revij - Educational Technology Research and Development, British Journal of Educational Technology, Journal of Emerging Technologies in Learning in drugih. Je aktivna članica Združenja za izobraževalno Tehnologijo (AECT - Association for Educational Communications and Technology) v ZDA, v okviru katere je bila leta 2018 član organizacijskega odbora simpozija o prihodnosti učenja, ki je potekal na Univerzi Severnega Teksasa. Je članica Kitajskega združenja za izobraževalno tehnologijo in sodeluje $z$ Univerzo $v$ Pekingu in več univerzami na Tajvanu. Aktivno deluje $v$ Evropski organizaciji za raziskovanje $v$ izobraževanju (EERA - European Educationa Research Association) in Združenju za izobraževanje učiteljev v Evropi (ATEE - Association for Teacher Education in Europe). V EERA je bila ustanovna članica NW27 Didaktika. Je tudi članica Slovenskega društva za raziskovanje $v$ edukaciji (SLODRE) in Britanskega združenja za raziskovanje $v$ izobraževanju (BERA - British Education Research Association). V zadnjih letih raziskuje na področju evalvacije znanosti v družboslovju in humanistiki in je članica EVALHUM - Research Evaluation, Innovation and Impact Analysis for the Social Sciences and Humanities.

Soizdajatelj:

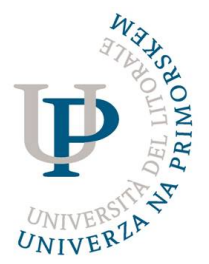

